BÁO CÁO CHUYÊN ĐỀ

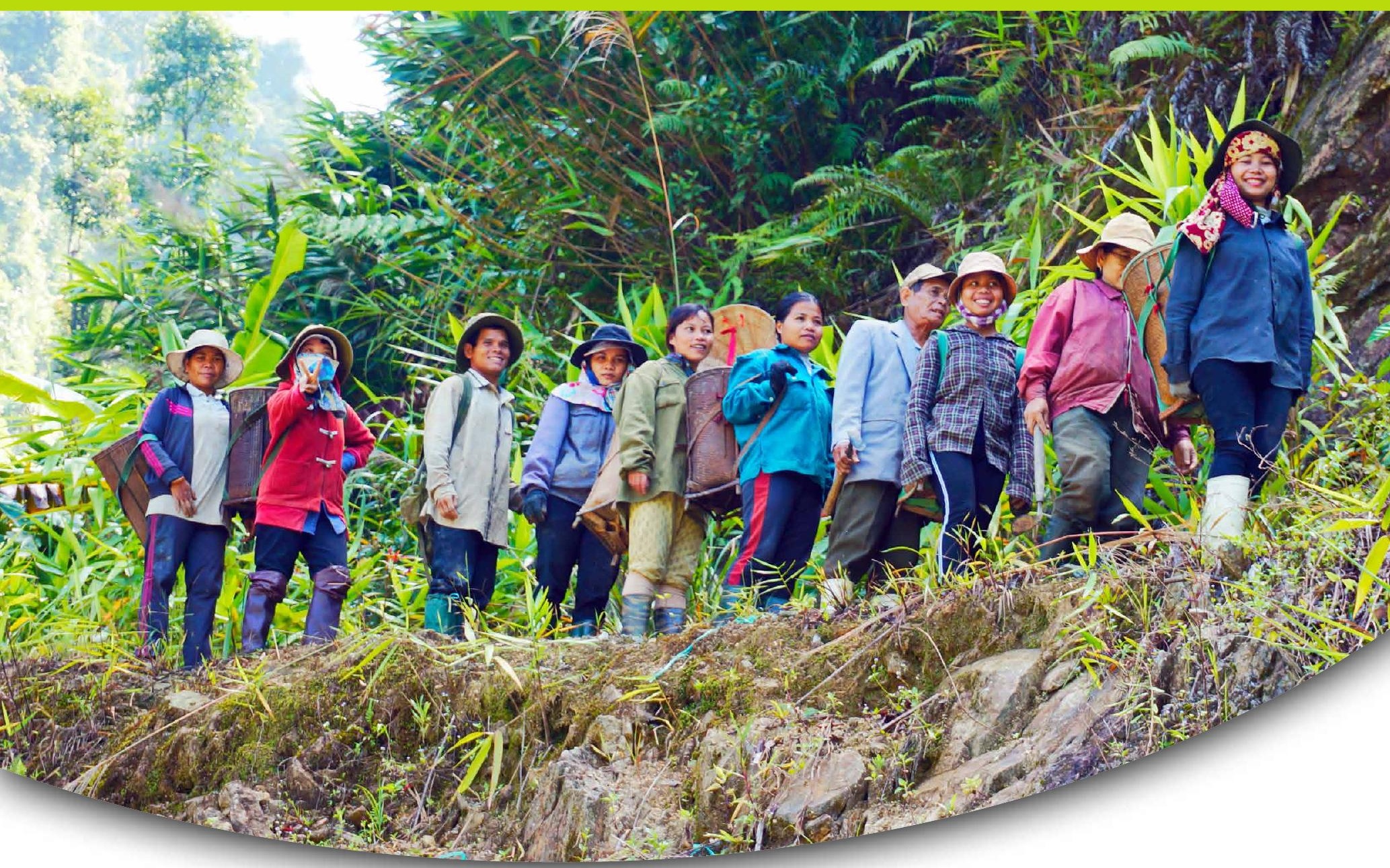

\title{
Tác động của chi trả dịch vụ môi trường rừng tại Thừa Thiên Huế đến đời sống kinh tế xã hội của cộng đồng
}

Bài học từ huyện $A$ Lưới- tỉnh Thừa Thiên Huế

Dương Ngọc Phước

Phạm Thu Thủy

Lê Thị Thanh Thủy

Nguyễn Thị Diệu Hiền

Đỗ Thị Thu Ái
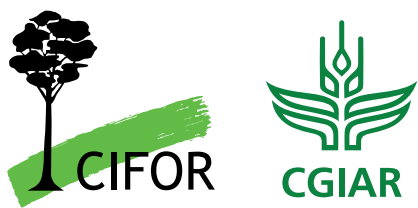



\section{Tác động của chi trả dịch vụ môi trường rừng tại Thừa Thiên Huế đến đời sống kinh tế xã hội của cộng đồng}

Bài học từ huyện $A$ Lưới- tỉnh Thừa Thiên Huế

Dương Ngọc Phước

Trường Đại học Nông lâm, Đại học Huế

Phạm Thu Thủy

Tổ chức Nghiên cứu Lâm nghiệp Quốc tế (CIFOR)

Lê Thị Thanh Thủy

Nghiên cứu viên độc lập

Nguyễn Thị Diệu Hiền

Trường Đại học Nông lâm, Đại học Huế

Đỗ Thị Thu Ái

Trường Đại học Nông lâm, Đại học Huế 
Báo cáo chuyên đề 225

@ 2021 Tổ chức Nghiên cứu Lâm nghiệp Quốc tế (CIFOR)

(i) Nội dung trong ấn phẩm này được cấp quyền bởi Giấy phép bản quyền Ghi nhận công của tác giả - Phi thương mại, không chỉnh sửa, thay đổi hay phát triển - Không phát sinh 4.0. http://creativecommons.org/ licenses/by-nc-nd/4.0/

ISBN: 978-602-387-164-3

DOI: $10.17528 /$ cifor/008206

Dương NP, Phạm TT, Lê TTT, Nguyễn TDH và Đỗ TTÁ. 2021. Tác động của chi trả dịch vụ môi trường rừng tại Thừa Thiên Huế đến đời sống kinh tếxã hội của cộng đồng: Bài học từ huyện A Lưới- tỉnh Thừa Thiên Huế. Báo cáo chuyên đề 225. Bogor, Indonesia: CIFOR.

Ảnh được chụp bởi Ho Dang Nguyen

Người dân Thừa Thiên Huế đi tuần tra rừng

CIFOR

Jl. CIFOR, Situ Gede

Bogor Barat 16115

Indonesia

$\mathrm{T}+62$ (251) 8622-622

$F+62(251) 8622-100$

E cifor@cgiar.org

\section{cifor.org}

Chúng tôi xin cảm ơn các nhà tài trợ đã hỗ trợ cho nghiên cứu này thông qua việc đóng góp vào quỹ của CGIAR. Xin xem danh sách các nhà tài trợ: http://www.cgiar.org/about-us/our-funders/

Tất cả các quan điểm thể hiện trong ấn phẩm này là của các tác giả. Chúng không nhất thiết đại diện cho quan điểm của CIFOR, các cơ quan chủ quản của tác giả hay của các nhà tài trợ cho ấn phẩm này. 


\section{Mục lục}

Danh mục từ viết tắt $\quad$ vi

Lời cảm ơn vii

Tóm tắt tổng quan viii

1 Giới thiệu 1

2 Đối tượng và phương pháp nghiên cứu 3

2.1 Đối tượng nghiên cứu 3

2.2 Phương pháp nghiên cứu 3

3 Bối cảnh địa bàn nghiên cứu $\quad 7$

$\begin{array}{lll}3.1 \text { Tỉnh Thừa Thiên Huế } & 7\end{array}$

3.2 Huyện A Lưới

4 Tác động xã hội của PFES 9

4.1 Tác động an sinh xã hội 9

4.2 Tác động của PFES đối với xóa đói giảm nghèo tại địa phương 10

4.3 PFES và tiếp cận tài nguyên để thúc đẩy sinh kế bền vững 13

5 Tác động kinh tế $\quad 19$

$\begin{array}{ll}5.1 \text { Thu nhập của hộ nghiên cứu } & 19\end{array}$

5.2 Đóng góp nguôn thu và tác động của thu nhập từ PFES 27

5.3 Sử dụng tiên chi trả PFES và các vấn đê liên quan 30

6 Kết luận 37

Tài liệu tham khảo 38 


\section{Danh mục bảng và hình}

\section{Bảng}

1 Các thôn được lựa chọn nghiên cứu

2 Đối tượng tham gia phỏng vấn người am hiểu

3 Số người tham gia thảo luận nhóm tại mỗi thôn

4 Phân loại hộ gia đình

5 Đặc điểm chủ hộ phỏng vấn 6

6 Các bước thoát nghèo của cộng đông (tổng hợp của tất cả các thôn nghiên cứu) 11

7 Số hộ nghèo ở các thôn có nguôn thu nhập từ PFES 11

8 Tiêu chí phân loại hộ do cộng đồng xác định tại thôn Ta Lo A Hố và A Đeeng

$\begin{array}{ll}\text { Par Lieng } 1 \text { (có PFES) huyện A Lưới } & 12\end{array}$

9 Diện tích và cơ cấu sử dụng đất của các nhóm hộ khảo sát 14

10 Tỷ lệ sở hữu nhà của các nhóm hộ khảo sát 15

11 Giá trị phương tiện hoặc tài sản các nhóm hộ khảo sát 16

12 Sử dụng điện của nhóm hộ điều tra 18

13 Sử dụng vật liệu đun nấu của nhóm hộ điều tra 18

14 Tình hình lao động ở địa bàn nghiên cứu 19

15 Tình hình sử dụng lâm sản của hộ khảo sát $\quad 21$

16 Thu nhập từ trông trọt của các nhóm hộ khảo sát 23

17 Thu nhập từ chăn nuôi của hộ 26

18 Cơ cấu kế hoạch chi tiêu trung bình hàng năm từ tiền PFES của các cộng đồng được khảo sát 28

19 Kế hoạch chi tiêu năm 2019 của cộng đồng thôn 2 - Hồng Trung (cộng đông A Đeeng Par Lieng 1) 28

20 So sánh giữa kế hoạch chi tiêu đã phê duyệt và trên thực tế 29

21 Tổng số tiền PFES chi trả cho các địa điểm khảo sát năm 2019

22 Tổng hợp các loại thu nhập của các hộ tham gia PFES (triệu đông/hộ) 34

\section{Hình}

1 Mức độ đáp ứng của thu nhập đối với nhu câu đời sống 9

2 Lý do các hộ khảo sát nêu ra khi thu nhập không đáp ửng nhu câuu 10

3 Thu nhập phân theo kinh tế hộ 13

4 Nguôn nước sinh hoạt và sản xuất của nhóm hộ điều tra 17

5 Tỷ lệ hộ khai thác lâm sản ngoài gỗ trước và sau PFES 20

6 Sản lượng khai thác và bán lâm sản ngoài gỗ trước và sau PFES của các hộ khảo sát 20

7 Lý do hộ tiêu dùng và bán lâm sản ít đi 22

8 Sản lượng tiêu dùng và buôn bán các cây trông chính trước và sau PFES 23

9 Số hộ và các nông sản hộ ngừng sản xuất (số hộ) 24

10 Lý do các hộ khảo sát chuyển đổi cây trông (ĐVT: \%) 24

11 Số lượng vật nuôi tại các nông hộ

12 Cơ cấu chi phí chăn nuôi của nông hộ (ĐVT: triệu đồng) 26

13 Tỷ lệ và thu nhập trung bình hộ từ các khoản thu nhập khác (\%) 27

14 Tỷ lệ hộ tham gia quyết định sử dụng và biết về quản lý tiền PFES 31

15 Tỷ lệ hộ biết đối tượng và thời hạn chi trả PFES 31 
16 Đối tượng chi trả PFES theo quan điểm của các hộ 32

17 Ý kiến của hộ về thời hạn thanh toán và việc chi trả đúng hạn 32

18 Những người hộ liên hệ khi có thắc mắc về PFES 33

19 Số tiên PFES cộng đông các thôn nhận được năm 2019

20 Số tiền PFES các hộ nhận được năm 2019

21 Các nguôn thu nhập của hộ được nhận tiên từ PFES 34

22 Cơ cấu thu nhập của các hộ nhận được tiên PFES 35

23 Tỷ lệ đóng góp của tiền PFES vào thu nhập của hộ 35

24 Mục đích sử dụng tiền PFES của hộ 36

25 Đánh giá của hộ về tác động của PFES 36 


\title{
Danh mục từ viết tắt
}

\author{
DVMTR Dịch vụ môi trường trừng \\ CIFOR Trung Tâm Nghiên cứu Lâm Nghiệp Quốc Tế \\ PES \\ Chi trả dịch vụ hệ sinh thái \\ PFES \\ Chính sách Chi trả Dịch vụ môi trường rừng \\ QĐ \\ Quyết định \\ UBND \\ FAO \\ Uỷ Ban Nhân Dân \\ Tổ chức Lương thực và Nông Nghiệp Liên Hiệp Quốc
}




\section{Lời cảm ơn}

Chúng tôi xin cảm ơn các nhà tài trợ đã hỗ trợ nghiên cứu này bao gồm Cơ quan Hợp tác Phát triển $\mathrm{Na}$ Uy (Norad), Cơ quan Phát triển Quốc tế Hoa Kỳ (USAID), và Chương trình Nghiên cứu CGIAR về Rừng, Cây gỗ và Nông lâm kết hợp (CRP-FTA), với sự hỗ trợ tài chính từ các nhà tài trợ đóng góp cho Quỹ CGIAR.

Chúng tôi xin gửi lời cảm ơn tới Ông Trần Xuân Cảnh, Phó giám đốc Quỹ Bảo vệ và Phát Triển Rừng tỉnh Thừa Thiên Huế đã hỗ trợ trong suốt quá trình nghiên cứu. Nhóm nghiên cứu cũng xin chân thành cám ơn các ông, bà: Trân Thị Thu Phương, Nguyễn Hồng Sơn, Nguyễn Thanh Hạ, Cao Thị Thuyết đã hỗ trợ trong quá trình thu thập số liệu. Chúng tôi cũng xin chân thành cảm ơn UBND các xã, UBND huyện A Lưới, Quỹ Bảo vệ và Phát Triển rừng tỉnh Thừa Thiên Huế, bà con các dân tộc các địa bàn nghiên cứu đã hỗ trợ nhiệt tình cho quá trình triển khai các hoạt động khảo sát thực địa cũng như cung cấp các thông tin hữu ích cho nhóm nghiên cứu. 


\section{Tóm tắt tổng quan}

Báo cáo này đưa ra một bức tranh tổng thể vê đời sống của những người dân sinh sống tại 12 thôn của huyện $\mathrm{A}$ Lưới, tỉnh Thừa Thiên Huế và vai trò của Chính sách Chi trả dịch vụ môi trường rừng (PFES) đối với sinh kế và đời sống xã hội nơi đây.

Kết quả nghiên cứu chỉ ra rằng $100 \%$ các hộ tham gia khảo sát là người dân tộc thiểu số, tỷ lệ hộ nghèo và cận nghèo ở cả 2 nhóm tham gia và không tham gia PFES đều rất lớn (hơn 50\%). Tỷ lệ hộ nghèo tại các thôn tham gia PFES thấp hơn $11.21 \%$ so với thôn không tham gia PFES.

Diện tích đất nhỏ, thiếu vốn khiến quy mô sản xuất nông nghiệp, chăn nuôi của các hộ đều rất nhỏ. Tuy nhiên, các hộ tham gia PFES có diện tích đất trung bình cao hơn các hộ ở thôn đối chứng không có PFES ở cả thời điểm trước và sau khi PFES ra đời. Kết quả khảo sát cho thấy giá trị trung bình tài sản ngoài rừng của các hộ đã tăng sau khi PFES ra đời đối với cả hai nhóm hộ tham gia và không tham gia PFES, trong khoảng 21.89 - 23.79 triệu đồng/hộ. Trong đó, các hộ tham gia PFES có tài sản giá trị trung bình cao hơn hộ không tham gia.

Với việc đóng cửa rừng tự nhiên, người dân chỉ còn được khai thác lâm sản ngoài gỗ nhưng tài nguyên đang cạn kiệt dần, tăng cường luật pháp và những biến động thị trường làm giá trị thu về từ lâm sản ngoài gố rất hạn chế. Thu nhập của người dân chủ yếu đến từ công việc làm thuê mướn. Trong bối cảnh đó, với mức chi trả trung bình là 1.64 triệu đông/hộ/năm, tiền từ chi trả dịch vụ môi trường rừng là nguôn thu lớn thứ năm trong các khoản thu nhập của hộ và trung bình đóng góp $2.67 \%$ vào thu nhập hộ.

Với khoản tiền nhận được từ PFES, gánh nặng sinh hoạt phí của người dân đã phần nào được chia sẻ và nguôn ngân sách chi cho các hoạt động công ích của thôn bản đã được mở rộng. $80 \%$ hộ khảo sát đã sử dụng tiền PFES để mua nhu yếu phẩm cho gia đình như gia vị, gạo, thực phẩm. Đặc biệt thời điểm chi trả là gần Tết Nguyên Đán nên số tiên nhận được từ PFES rất có ý nghĩa đối với người dân để họ có một cái Tết ý nghĩa hơn. Tiên PFES cũng được hộ dùng để trả nợ, đóng học cho con cái và mua phân bón, cây giống để đầu tư sản xuất. Đây đều là những nhu câu thiết yếu mà với thu nhập hiện tại, các hộ dân không đủ để chi trả.

Về tính pháp lý, sau khi PFES ra đời, có sự tăng nhẹ trong tỷ lệ đất có chứng nhận quyền sử dụng đất trong tất cả các thôn khảo sát (cả tham gia và không tham gia $\mathrm{PFES}$ ). So sánh các cặp đối chứng trong cùng một xã cho thấy tỷ lệ có giấy chứng nhận quyển sử dụng đất của các hộ tham gia PFES cao hơn hộ không tham gia PFES cả trước và sau khi PFES ra đời.

Về tác động xã hội, tiền PFES đã được sử dụng để cải thiện điều kiện cơ sở vật chất thôn bản như đóng góp cho thôn sửa điện, mua bàn ghế, cải tạo nhà văn hóa, xây dựng cổng chào thôn, đóng góp vào quỹ ma chay cưới hỏi, tổ chức họp tổng kết và thậm chí trích cho Hội Phụ nữ, Hội Nông dân để họ có thêm kinh phí hoạt động. Trước đây khi chưa tiến hành PFES, để tổ chức các hoạt động cộng đông thì đều phải vận động sự đóng góp của thành viên, từ khi có hỗ trợ của PFES, thay vì đóng góp như trước bà con đều tự nguyện trích từ tiền của cộng đồng cho các hoạt động, vừa tạo tính đoàn kết vừa đỡ một mối lo đóng góp.

Về quá trình ra quyết định và triển khai PFES tại thôn bản, chỉ có $48 \%$ hộ khảo sát từng nghe tới PFES, có rất ít hộ biết về việc tiền PFES được quản lý như thế nào và khi được hỏi ai là người chi trả dịch vụ môi trường rừng thì đa phần các hộ chỉ biết trưởng thôn và thủ quỹ xã là những người đưa tiền trực tiếp cho họ. Có $4 \%$ hộ nói 
tới thủy điện, $16 \%$ nhắc tới Quỹ bảo vệ rừng, $6 \%$ nói kiểm lâm và có $1 \%$ nói là Nhà nước chi tiền. Vai trò của trưởng thôn trưởng bản cũng được khẳng định rõ qua các cuộc khảo sát khi hơn 89\% hộ chia sẻ họ biết mọi thông tin vê PFES qua trưởng thôn và trưởng thôn cũng là người đâu tiên họ liên hệ khi có những thắc mắc trong quá trình chi trả.

Tuy nhiên, việc thực hiện chính sách chi trả dịch vụ môi trường rừng cũng còn gặp phải nhiêu thách thức đặc biệt liên quan đến vấn đê chi trả, theo quy định việc chi trả được giải ngân 02 lần trong năm, tuy nhiên đa số cộng đông chỉ thực hiện thanh toán cuối năm nên phải tự ứng tiền trước để tham gia tuân tra rừng trong khi mức thu nhập của họ rất thấp. Mức chi trả hiện vẫn còn thấp so với thời gian các hộ phải bỏ ra để đi tuân tra rừng và mỗi hộ chỉ được cử một đại diện tham gia trong khi vẫn còn lực lượng thanh niên và nhiêu người đều muốn góp sức vào công tác bảo vệ rừng. Để giải quyết những hạn chế này, các hộ đã đưa ra nhiều đề xuất, được nhắc tới nhiều nhất là việc cần tăng mức chi trả tiên công cho người đi bảo vệ rừng. Bên cạnh đó cần đẩy mạnh hơn nữa công tác tuyên truyền, nâng cao nhận thức và tập huấn cho người dân. Tính công khai, minh bạch trong thu chi của cấp cộng đồng cũng cần được đảm bảo. 



\section{Giới thiệu}

Chi trả dịch vụ môi trường (PES) được coi là một giải pháp hiệu quả để giúp thế giới cải thiện chất lượng và dịch vụ môi trường và xóa đói giảm nghèo ở các vùng nông thôn (Landell-MillsIna \& Porras, 2002). Tuy nhiên, các kết quả nghiên cứu trên toàn câuu nói chung và Việt Nam nói riêng đưa ra những bức tranh khác nhau về tác động của PES đối với xóa đói giảm nghèo.

Một số nghiên cứu chỉ ra rằng, PES chỉ đem lại hiệu quả của công tác quản lý tài nguyên thiên nhiên chứ không đem lại hiệu quả trong xóa đói giảm nghèo (Pagiola, 2003) và những hộ nghèo có thể sẽ không tự nguyện tham gia chương trình PES, nếu số tiền chi trả PES không bù đắp được các chi phí cơ hội cho việc thay đổi loại hình sử dụng đất (Wunder, 2008). Ngoài ra, những người nghèo, người cung cấp dịch vụ môi trường cũng có thể không tham gia được vào chương trình này, do quyê̂n sở hữu đất không đảm bảo, hoặc diện tích đất rừng của họ quá nhỏ, hoặc thiếu tiếp cận tín dụng để đâu tư vào các hoạt động như trông rừng (Grieg-Gran và nnk, 2005). Tuy nhiên, cũng có nhiêu nghiên cứu chỉ ra rằng PES đóng vai trò quan trọng trong xóa đói giảm nghèo tại Việt Nam (Phú, 2009) và những hộ gia đình nghèo đã tiếp cận được với chi trả dịch vụ môi trường rừng nhận được khoản chi trả nhiều hơn so với những hộ giàu hay khá (Huệ và nnk, 2013). Liệu PES có thể giúp xóa đói giảm nghèo hay không phụ thuộc vào thiết kế của $\mathrm{PES}$, các điều kiện kinh tế, chính trị và xã hội của địa phương, năng lực của các bên có liên quan, diện tích và chất lượng rừng hiện có và quá trình ra quyết định. Việc tổng hợp các bài học hiện có để xác định các điều kiện cần và đủ để giúp nâng cao hiệu quả của PES đối với đời sống của người dân là rất cân thiết.

Việt Nam là nước đâu tiên ở khu vực Châu Á xây dựng chính sách chi trả dịch vụ môi trường rừng (PFES). Ngoài mục tiêu tạo ra nguôn tài chính để bảo vệ rừng, PFES cũng đặt trọng tâm vào xóa đói giảm nghèo. Tuy nhiên, chưa có nhiêu đánh giá khoa học về tiềm năng và tác động của PFES vào công cuộc xóa đói giảm nghèo. Mặc dù đã có một số nghiên cứu đánh giá tác động của PFES đối với sinh kế địa phương như nghiên cứu của Lê Trọng Toán (2014), Huong và nnk (2016), Ngoc \& de Groot (2018), các nhà hoạch định chính sách vẫn kêu gọi các nhà khoa học trong và ngoài nước tiến hành thêm nhiêu nghiên cứu để xây dựng một nguồn số liệu tổng thể và toàn diện trên quy mô cả nước.

Báo cáo này là một trong những nỗ lực đáp ứng lời kêu gọi này. Dựa trên trường hợp nghiên cứu điểm tại tỉnh $\mathrm{A}$ Lưới, Thừa Thiên Huế, báo cáo này xem xét và phân tích các tác động xã hội và kinh tế mà $P F E S$ đem lại cho người dân địa phương, từ đó đề xuất các giải pháp góp phân nâng cao hiệu quả thực hiện PFES trong những năm tới.

Tỉnh Thừa Thiên Huế với diện tích tự nhiên $502.629,57$ ha. Trong đó, diện tích rừng và đất lâm nghiệp 348.836,90 ha (283.003,00 ha đất có rừng và $70.830,80$ ha rừng trông); trong 283.003,00 ha đất có rừng thì có 212.172,20 ha rừng tự nhiên, tỷ lệ che phủ rừng toàn tỉnh đạt 56,3\% (Cục Thống Kê Tỉnh Thừa Thiên Huế, 2020). Các đối tượng tham gia và chi trả DVMTR là các nhà máy thủy điện, các nhà máy nước sạch và các đơn vị kinh doanh du lịch trên địa bàn tỉnh. Mức chi trả được thực thiện theo Nghị định 156/2018/NĐ-CP.

Huyện A Lưới được lựa chọn là khu vực nghiên cứu điểm để đánh giá tác động của Chính sách Chi trả Dịch vụ môi trường rừng (PFES) tại Thừa Thiên Huế bởi huyện vừa có địa bàn được hưởng lợi từ PFES (Bắt đâu từ năm 2014) vừa có địa bàn không được hưởng lợi từ PFES. Năm 2019, đơn giá chi trả trên 1 ha rừng cung ứng 
dịch vụ môi trường rừng lưu vực thủy điện $\mathrm{A}$ Lưới là 600.000 đông, cao nhất toàn tỉnh trong khi tại các địa phương khác trong tỉnh chỉ ở mức 400.000 đông (Quỹ Bảo vệ và Phát Triển Rừng tỉnh Thừa Thiên Huế, 2020). Với 75\% diện tích được rừng bao phủ, Huyện $\mathrm{A}$ Lưới có diện tích rừng toàn huyện năm 2019 là $91,877.19$ ha trong đó diện tích rừng tự nhiên chiếm hơn $31.86 \%$ diện tích rừng tự nhiên toàn tỉnh (Niên giám thống kê tỉnh Thừa Thiên Huế, 2020). Tuy nhiên, trong nhiều năm qua, A Lưới luôn là điểm nóng của tình trạng chặt phá và khai thác rừng trái phép (BT, 2019). Nơi đây cũng có số lượng người dân tộc tại chỗ như người Tà Ôi, Pa Cô và cộng đông các dân tộc di cư từ nơi khác đến tương đối lớn (DT, 2019). Vì vậy, nghiên cứu trường hợp tại $\mathrm{A}$ Lưới có thể giúp minh họa tác động của PFES tới cộng đông địa phương trên đây đủ các khía cạnh kinh tế, môi trường và xã hội 


\section{2 Đối tượng và phương pháp nghiên cứu}

\section{1 Đối tượng nghiên cứu}

Nghiên cứu được triển khai thực hiện ở địa bàn 7 xã, 12 thôn thuộc huyện $\mathrm{A}$ Lưới, tỉnh Thừa Thiên Huế (Bảng 1). Đây là các xã đại diện có các nhóm chủ rừng là hộ gia đình và cộng đông tham gia vào quản lý và bảo vệ rừng.

\subsection{Phương pháp nghiên cứu}

Trong nghiên cứu này, chúng tôi áp dụng phương pháp đánh giá tác động của PFES tại Việt Nam được phát triển bởi Thuy và nnk (2019). Phương pháp này so sánh tác động của PFES trước và sau khi có $\mathrm{PFES}$, ở nơi có PFES (can thiệp) và nơi không có PFES (đối chứng). Chúng tôi tiến hành cả phương pháp thu thập số liệu thứ cấp và sơ cấp.

Phương pháp thu thập số liệu thứ cấp. Nhóm nghiên cứu thu thập và rà soát số liệu thứ cấp được cung cấp bởi Quỹ Bảo vệ và Phát Triển rừng của tỉnh Thừa Thiên Huế, Chi Cục kiểm Lâm Tỉnh Thừa Thiên Huế, Hạt Kiểm Lâm huyện A Lưới, UBND các xã, các nghiên cứu và tài liệu, báo cáo khoa học và của các nhà tài trợ. Chúng tôi cũng kế thừa, tham khảo số liệu khoa học liên quan đến đề tài nghiên cứu trong các bài báo cáo khoa học, tạp chí, trang web, các công trình nghiên cứu trong và ngoài nước.

Phương pháp thu thập số liệu sơ cấp. Chúng tôi cũng tiến hành phỏng vấn sâu với 31 cán bộ địa phương, bao gồm trưởng thôn của các thôn có PFES và không có $P F E S$, kiểm lâm địa bàn, Ban quản lý rừng cộng đồng tại địa phương về thực trạng công tác quản lý, bảo vệ rừng cộng động; việc hiệu quả thực hiện chi trả DVMTR có ảnh hưởng đến đời sống của người dân trong khu vực xã Nhâm, huyện A Lưới, tỉnh Thừa Thiên Huế (Bảng 2).
Ngoài ra, chúng tôi tiến hành thảo luận 12 nhóm những người tham gia vào chương trình chi trả DVMTR, mỗi nhóm tử 8-10 người. Tại mỗi thôn, nhóm nghiên cứu đã tiến hành thảo luận nhóm với 3 nhóm, Nhóm nam (> 30 tuổi), nhóm nữ (>30 tuổi) và nhóm cả nam và nữ ( $<30$ tuổi). Trong mỗi nhóm thảo luận sẽ có đại diện các nhóm dân tộc, có hộ tham gia vào $\mathrm{PFES}$ và có hộ không tham gia vào $\mathrm{PFES}$ và có các chủ rừng khác nhau. Tổng số người tham gia thảo luận nhóm là 358 người được trình bày chi tiết trong Bảng 3.

Nhóm nghiên cứu cũng tiến hành phỏng vấn bán cấu trúc với các hộ gia đình (Bảng 4). Dựa trên danh sách hộ gia đình được cung cấp bởi trưởng thôn, với mỗi một thôn 30 hộ ngẫu nhiên đã được lựa chọn để tiến hành phỏng vấn sâu người dân địa phương tham gia và không tham gia vào chương trình chi trả DVMTR, tìm hiểu quan điểm của người dân về những thay đổi trước và sau khi thực hiện chính sách chi trả DVMTR trong khu vực liên quan tới tiếp cận điện, nước, tài sản vật chất, nhà ở, phương tiện giao thông, thu nhập, tiếp cận đất đai, sinh kế và an sinh xã hội. Đây cũng là là những yếu tố liên quan đến đánh giá nghèo đa chiều theo Quyết định Số: 59/2015/QĐ-TTg của Thủ tướng chính phủ ngày 19 tháng 11 năm 2015 về việc ban hành chuẩn nghèo tiếp cận đa chiều áp dụng cho giai đoạn 2016 - 2020. Đông thời nhóm nghiên cứu cũng tiến hành đánh giá tác động của PFES đến đời sống kinh tế, xã hội và văn hóa của người dân dựa trên khung sinh kế bền vững, đánh giá tác động PFES với 5 nguồn tài sản chính: tiếp cận đất đai, tài sản, tài chính, xã hội và con người.

Riêng về trình độ học vấn, chủ hộ được khảo sát đến từ các thôn tham gia PFES có trình độ cao hơn thôn không tham gia, được thể hiện qua tỷ lệ trung bình người có bằng đại học/cao đẳng/ trung cấp nghể là $8.23 \%$ trong khi tỷ lệ này ở thôn không tham gia PFES chỉ là 3.25\%. Tỷ lệ tốt 
Bảng 1. Các thôn được lựa chọn nghiên cứu

\begin{tabular}{|c|c|c|c|c|c|c|c|c|c|c|c|c|}
\hline \multirow{3}{*}{$\begin{array}{l}\text { Tiêu } \\
\text { chí }\end{array}$} & \multicolumn{8}{|c|}{ Nghiên cứu sâu } & \multirow{2}{*}{\multicolumn{4}{|c|}{$\begin{array}{c}\text { Nghiên cứu rộng } \\
\text { Có PFES }\end{array}$}} \\
\hline & \multicolumn{4}{|c|}{ Không PFES } & \multicolumn{4}{|c|}{ Có PFES } & & & & \\
\hline & $\begin{array}{l}\text { Thôn } \\
\text { Talo-A } \\
\text { Hố } \\
\text { (Hồng } \\
\text { Vân) }\end{array}$ & $\begin{array}{c}\text { Thôn } \\
\text { A Niên } \\
\text { - Lê } \\
\text { Triêng } \\
1 \text { (Hồng } \\
\text { Trung) }\end{array}$ & $\begin{array}{l}\text { Thôn } \\
\text { TaayTa } \\
\text { - (Hông } \\
\text { Trung) }\end{array}$ & $\begin{array}{l}\text { Thôn } \\
\text { Ta Kêu } \\
\text { (Nhâm) }\end{array}$ & $\begin{array}{c}\text { Thôn } \\
\text { Đeeng } \\
\text {-Parlieng } \\
1 \text { (Bắc } \\
\text { Sơn) }\end{array}$ & $\begin{array}{l}\text { Thôn } \\
\text { Đụt -Lê } \\
\text { Triêng } \\
2 \text { (Hồng } \\
\text { Trung) }\end{array}$ & $\begin{array}{l}\text { Thôn } \\
\text { Đeeng } \\
\text {-Parlieng } \\
2 \text { (Bắc } \\
\text { Sơn) }\end{array}$ & $\begin{array}{l}\text { Thôn } \\
\text { A Hưa } \\
- \text { PaE } \\
\text { (Nhâm) }\end{array}$ & $\begin{array}{c}\text { Thôn Hương } \\
\text { Phú- (Hương } \\
\text { Phong) }\end{array}$ & $\begin{array}{c}\text { Thôn Paring - } \\
\text { Căn Sâm (Hồng } \\
\text { Hạ) }\end{array}$ & $\begin{array}{c}\text { Thôn KaLeng } \\
\text {-A Bung } \\
\text { (Nhâm) }\end{array}$ & $\begin{array}{l}\text { Thôn } \\
\text { A Tia } 1 \\
\text { (Hồng } \\
\text { Kim) }\end{array}$ \\
\hline $\begin{array}{l}\text { Tổng } \\
\text { số hộ }\end{array}$ & 170 & 200 & 200 & 78 & 140 & 165 & 160 & 67 & 115 & 103 & 60 & 70 \\
\hline $\begin{array}{l}\text { Tổng } \\
\text { diện } \\
\text { tích } \\
\text { rừng }\end{array}$ & 310 & 1460 & 1200 & 100 & 800 & 1300 & 650 & 59 & 1500 & 400 & 67 & 630 \\
\hline $\begin{array}{l}\text { Số hộ } \\
\text { nghèo }\end{array}$ & 39 & 89 & 87 & 30 & 35 & 69 & 39 & 20 & 1 & 20 & 7 & 19 \\
\hline $\begin{array}{l}\text { Dân } \\
\text { tộc }\end{array}$ & Paco & Paco & Paco & Ta Ôi & Paco & Paco & Paco & Tà Ôi & Kinh & CơTu & Tà Ôi & Paco \\
\hline $\begin{array}{l}\text { Thu } \\
\text { nhập } \\
\text { chính }\end{array}$ & $\begin{array}{l}\text { Lúa, sắn, } \\
\text { trồng } \\
\text { keo, làm } \\
\text { thuê }\end{array}$ & $\begin{array}{l}\text { Chăn } \\
\text { nuôi, } \\
\text { trồng } \\
\text { keo, làm } \\
\text { thuê }\end{array}$ & $\begin{array}{l}\text { Trồng keo, } \\
\text { sắn, làm } \\
\text { thuê }\end{array}$ & $\begin{array}{l}\text { Lúa, sắn, } \\
\text { trồng } \\
\text { keo, làm } \\
\text { thuê }\end{array}$ & $\begin{array}{l}\text { Chăn } \\
\text { nuôi, } \\
\text { trồng } \\
\text { keo, làm } \\
\text { thuê }\end{array}$ & $\begin{array}{l}\text { Trồng } \\
\text { keo, } \\
\text { sắn, làm } \\
\text { thuê, } \\
\text { chăn } \\
\text { nuôi }\end{array}$ & $\begin{array}{l}\text { Chăn } \\
\text { nuôi, } \\
\text { trồng } \\
\text { keo, làm } \\
\text { thuê }\end{array}$ & $\begin{array}{l}\text { Trồng } \\
\text { keo, } \\
\text { nông } \\
\text { nghiệp }\end{array}$ & $\begin{array}{l}\text { Trồng keo, } \\
\text { nông nghiệp }\end{array}$ & $\begin{array}{l}\text { Nông nghiệp } \\
\text { (cao su, trônng } \\
\text { rừng, chăn nuôi } \\
\text { làm rẫy }\end{array}$ & $\begin{array}{l}\text { Lúa, sắn, } \\
\text { trồng keo, } \\
\text { làm thuê }\end{array}$ & $\begin{array}{l}\text { Lúa, sắn, } \\
\text { trồng } \\
\text { keo, làm } \\
\text { thuê }\end{array}$ \\
\hline
\end{tabular}


Bảng 2. Đối tượng tham gia phỏng vấn người am hiểu

\begin{tabular}{|c|c|c|c|c|}
\hline Nhóm đối tượng & Đối tượng phỏng vấn & Nam & Nũ & Số người tham gia \\
\hline \multirow[t]{6}{*}{ Chính quyền địa phương } & UBND xã Hồng Vân & 1 & & \multirow[t]{6}{*}{6} \\
\hline & UBND xã Hồng Trung & 1 & & \\
\hline & UBND xã Bắc Sơn & 1 & & \\
\hline & UBND xã Nhâm & 1 & & \\
\hline & UBND xã Hồng Kim & 1 & & \\
\hline & UBND xã Hương Phong & 1 & & \\
\hline \multirow{3}{*}{$\begin{array}{l}\text { Cơ quan quản lý lâm } \\
\text { nghiệp chuyên trách }\end{array}$} & Hạt kiểm lâm huyện A Lưới & 1 & & \multirow[t]{3}{*}{7} \\
\hline & Chi cục kiểm lâm, Sở NN\&PTNT Thừa Thiên Huế & 1 & 2 & \\
\hline & Quỹ BVPTR tỉnh Thừa Thiên Huế & 4 & & \\
\hline \multirow[t]{2}{*}{ Cộng đồng } & Trưởng thôn và quản lý nhóm cộng đồng & 16 & 2 & 18 \\
\hline & Tổng cộng & 27 & 4 & 31 \\
\hline
\end{tabular}

Bảng 3. Số người tham gia thảo luận nhóm tại mỗi thôn

\begin{tabular}{|c|c|c|c|c|}
\hline \multirow{2}{*}{ STT } & \multirow{2}{*}{ Thôn } & \multicolumn{3}{|c|}{ Các nhóm thảo luận } \\
\hline & & Nhóm nam & Nhóm nữ & Nhóm nam nũ <30 \\
\hline 1 & Ta Lo A Hố & 11 & 11 & 9 \\
\hline 2 & A Niêng Lê Triêng 1 & 9 & 9 & 12 \\
\hline 3 & Ta Ay Ta & 9 & 8 & 10 \\
\hline 4 & Âr Kêu Nhâm & 9 & 8 & 16 \\
\hline 5 & A Đeeng Par Lieng 1 & 8 & 16 & 12 \\
\hline 6 & A Đeeng Par Lieng 2 & 10 & 12 & 10 \\
\hline 7 & A Hươr Pa E & 8 & 8 & 14 \\
\hline 8 & Đụt LêTriêng 2 & 14 & 8 & 9 \\
\hline 9 & Hương Phú & 9 & 11 & \\
\hline 10 & Pa Ring Cân Sâm & 10 & 9 & 9 \\
\hline 11 & KLeng A Bung & 9 & 13 & 10 \\
\hline 12 & A Tia 1 & 7 & 12 & 9 \\
\hline Tổng & & 113 & 125 & 120 \\
\hline
\end{tabular}

Bảng 4. Phân loại hộ gia đình

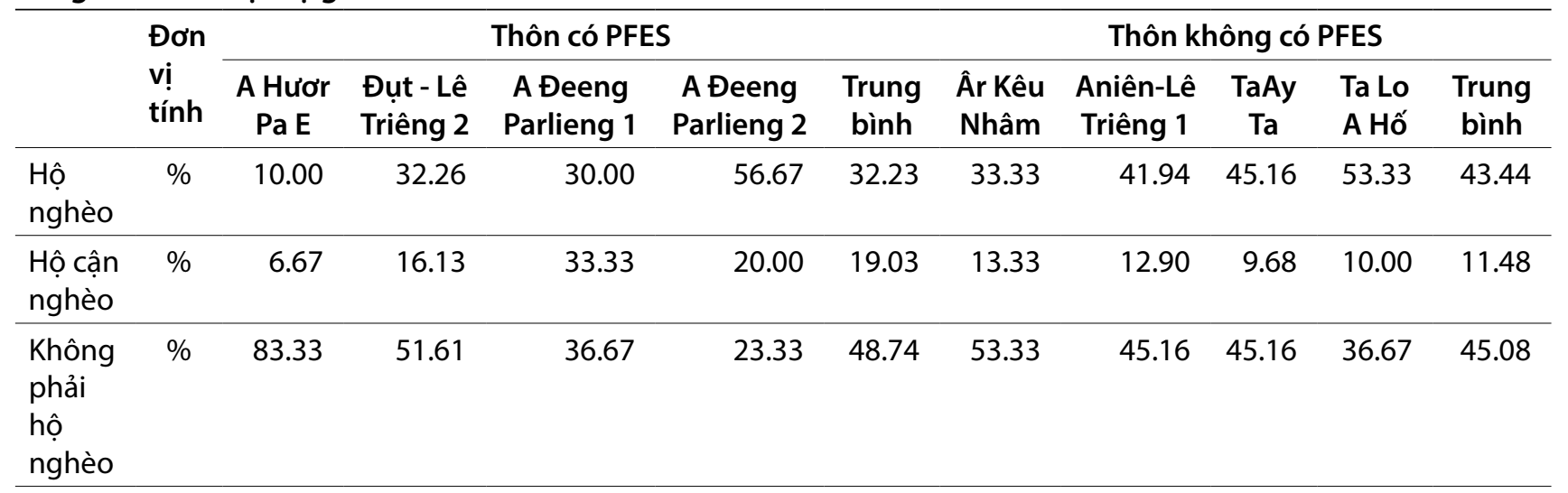


Bảng 5. Đặc điểm chủ hộ phỏng vấn

\begin{tabular}{lccc}
\hline Chỉ tiêu & Đơn vị tính & Thôn có PFES & Thôn không có PFES \\
\cline { 3 - 4 } & & Trung bình & Trung bình \\
\hline Giới tính & $\%$ & & \\
Nam & $\%$ & 90.91 & 88.55 \\
Nữ & & 9.09 & 11.45 \\
\hline Nghề nghiệp & $\%$ & & \\
Nông dân & $\%$ & 72.82 & 79.44 \\
Học sinh/sinh viên & $\%$ & 0.00 & 0.00 \\
Kinh doanh/buôn bán & $\%$ & 1.61 & 0.00 \\
Lao động có lương ổn định & $\%$ & 10.70 & 5.75 \\
Còn nhỏ & $\%$ & 0.00 & 0.00 \\
Khác & & 14.87 & 14.81 \\
\hline Trình độ học vấn & $\%$ & & 3.25 \\
Đại học/cao đẳng/trung cấp/nghề & $\%$ & 8.23 & 26.19 \\
THPT & $\%$ & 33.15 & 21.40 \\
THCS & $\%$ & 31.35 & 30.27 \\
Tiểu học & $\%$ & 14.87 & 0.00 \\
Còn nhỏ & $\%$ & 0.00 & 18.90 \\
Không đi học & $\%$ & 12.42 & 11.48 \\
\hline Độ tuổi & $\%$ & & 63.07 \\
Dưới 30 & $\%$ & 15.70 & 25.46 \\
Từ 30 đến 50 & $\% 4.63$ \\
Trên 50 & $\%$ oổi & 18.17 & \\
Bình quân & $\% 1.66$ & \\
\hline
\end{tabular}

Nguồn: Tổng hợp kết quả khảo sát, 2020

nghiệp THPT của nhóm tham gia PFES cũng cao hơn $6.96 \%$ so với nhóm không tham gia PFES. Kết quả so sánh bắt cặp cũng cho thấy xu hướng này như trong cùng xã Hông Trung, thôn Đụt Lê Triêng 2 (có tham gia PFES) có tỷ lệ chủ hộ không đi học chỉ là 9.68\% nhưng thôn A Niêng Lê Triêng 1 (không tham gia PFES) lại có tận $16.13 \%$ chủ hộ tham gia khảo sát không đi học.

Ngoài ra, báo cáo này được trình bày tại hội thảo lấy ý kiến báo cáo đánh giá tác động của chính sách chi trả dịch vụ môi trường rừng (DVMTR) tại tỉnh Thừa Thiên Huế giai đoạn 2011 - 2019 với sự tham gia của 38 đại biểu đến từ các bên liên quan như Quỹ bảo vệ và PTR tỉnh, Sở Nông Nghiệp và Phát Triển Nông Thôn, Chi cục Kiểm
Lâm, Phòng Nông Nghiệp và Phát Triển Nông Thôn huyện A Lưới, hạt kiểm lâm các huyện Nam Đông, Phong Điền, Phú Lộc; UBND các xã khảo sát, đại diện các thôn khảo sát; các đơn vị sử dụng dịch vụ như Công ty Cổ phần cấp nước Thừa Thiên Huế, Công ty Cổ phân Thủy điện miền Trung (Nhà máy Thủy điện $\mathrm{A}$ Lưới), Công ty Cổ phần Thủy điện Bình Điền (Nhà máy Thủy điện Bình Điền) để các bên trao đổi và đóng góp ý kiến về kết quả nghiên cứu, từ đó giúp nhóm tác giả hoàn thiện ấn phẩm này.

Phương pháp xử lý số liệu. Số liệu thu thập được làm sạch, kiểm tra chéo và phân tích định lượng bằng phần mềm Excel. 


\section{Bối cảnh địa bàn nghiên cứu}

\subsection{Tỉnh Thừa Thiên Huế}

Tỉnh Thừa Thiên Huế nằm trên trục giao thông quan trọng xuyên Bắc - Nam, trục hành lang Đông - Tây nối Thái Lan - Lào - Việt Nam theo đường 9 với diện tích $5,025.30 \mathrm{~km} 2$. Dân số toàn tỉnh tính đến cuối năm 2019 đạt 1,128,620 người. Thừa Thiên - Huế có 46 xã miền núi có đồng bào dân tộc thiểu số, với trên 54,350 người gồm các dân tộc Tà Ôi, Cơ-tu, Bru - Vân Kiều, Hoa, Pa Kôh, Mường, Thái và Thổ. Trong các dân tộc thiểu số sinh sống ở Thừa Thiên Huế thì các dân tộc: $\mathrm{Cơ} \mathrm{Tu}$, Tà Ôi, Bru-Vân Kiều được xem là người bản địa sinh sống ở phía Tây của tỉnh (Cục Thống Kê Tỉnh Thừa Thiên Huế, 2020).

Một trong những tài nguyên lớn được thiên nhiên ưu đãi cho Thừa Thiên Huế đó là tài nguyên mỏ, khoáng sản và tài nguyên nước dưới đất. Trên lãnh thổ Thừa Thiên Huế đã phát hiện được 120 mỏ, điểm khoáng sản với 25 loại khoáng sản, tài nguyên nước dưới đất, phân bố đều khắp, trong đó chiếm tỷ trọng đáng kể và có giá trị kinh tế là các khoáng sản phi kim loại và nhóm vật liệu xây dựng. Tuy nhiên, việc khai thác khoáng sản cũng gây ra nhiêu áp lực đối với tài nguyên rừng trên địa bàn.

Tốc độ tăng trưởng kinh tế năm 2019 của Thừa Thiên Huế đạt $7.18 \%$, giá trị tổng sản phẩm trong tỉnh (GRDP) đạt 31,330 tỷ đông, với đóng góp lớn nhất là khu vực dịch vụ du lịch khoảng 30\% - 40\% tổng giá trị tăng thêm của ngành; trong khi khu vực nông, lâm nghiệp tăng trưởng âm đạt - 4.13\% (thủy sản ước tăng $4 \%$; ngành lâm nghiệp tăng khoảng $3 \%$, nông nghiệp giảm $10 \%$, trong đó chăn nuôi giảm 42\%) năm 2019 (Niên giám thông kê tỉnh Thừa Thiên Huế, 2020). Theo số liệu những năm trước 2011 thì lâm nghiệp đóng góp khoảng 2-4\% GDP (Cục Thống Kê Tỉnh Thừa Thiên Huế, 2012).

\subsection{Huyện A Lưới}

A Lưới là một huyện miền núi được thành lập năm 1976, nằm ở phía Tây Nam của tỉnh Thừa Thiên - Huế, cách thành phố Huế hơn 70 km là huyện có diện tích lớn nhất tỉnh. Tổng diện tích tự nhiên của huyện năm 2019 là 122,521.21 ha. Trong đó đất nông nghiệp: 115,673.72 ha (chiếm 94.1\%); Đất phi nông nghiệp 5,454.04 ha; Đất chưa sử dụng: 1,393.45 ha (QĐ số $165 / Q Đ-U B N D$ ngày 16 tháng 01 năm 2020 của UBND tỉnh Thừa Thiên Huế về việc phê duyệt kế hoạch sử dụng đất năm 2020 của huyện A Lưới). Vào năm 2019, tổng dân số toàn huyện là 48,543 người; trong đó $78.50 \%$ là người dân tộc thiểu số tới từ 27 dân tộc (DT, 2019).

Địa hình $\mathrm{A}$ Lưới là vùng thượng nguôn của năm con sông lớn, trong đó có 2 sông chảy sang Lào là sông $A$ Sáp và sông $A$ Lin; 3 sông chảy sang phía Việt Nam là sông Đa Krông, sông Bồ và sông Tả Trạch (nhánh tả của sông Hương). Ngoài ra A Lưới còn có mạng lưới các suối phân bố hầu khắp trên địa bàn huyện. Phân lớn sông suối có độ dốc lớn, nhiều thác ghênh, lòng sông hẹp, thường bị sạt lở vào mùa mưa, gây khó khăn cho xây dựng câu, đường và đi lại.

A Lưới còn sở hữu một nguồn tài nguyên rừng và thảm thực vật lớn, tỷ lệ che phủ rừng cao, trũ̃ lượng trung bình 6-7 triệu $\mathrm{m}^{3}$ với nhiều loại gỗ quý như kiền, gõ, sến, lim, dổi, tùng... và nhiêu loại lâm sản khác như tre, nứa, lồ ô, mây. Động vật rừng đa dạng với một số loài như sao la, chôn hương, mang, nai ... thuộc nhóm động vật quý hiếm được bảo vệ (DT, 2019). 
A Lưới là một trong những huyện nghèo của tỉnh Thừa Thiên Huế, có 4,337 hộ nghèo chiếm 35.04\%; có 412 hộ cận nghèo, chiếm 3.33\% (2016). Trong tổng số hộ nghèo, hộ dân tộc thiểu số có 4,182 hộ, chiếm $96.43 \%$. Tổng số xã thụ hưởng Chương trình 135 có 14 xã, trong đó có 12 xã đặc biệt khó khăn (DT, 2019).
Năm 2019, thu nhập bình quân đầu người là 24.28 triệu đồng/người/năm. Tỷ trọng các ngành: Nông, lâm, ngư nghiệp là 38.7\%; Công nghiệp, tiểu thủ công nghiệp - Xây dựng là $30.7 \%$, và Dịch vụ là $30.6 \%$ (DT, 2019). 


\section{Tác động xã hội của PFES}

\subsection{Tác động an sinh xã hội}

Để tìm hiểu về nhu cầu an sinh, các hộ đã được yêu cầu tự đánh giá xem thu nhập của họ sau khi có PFES đã đáp ứng được nhu cầu của họ chưa. Kết quả trả lời cho thấy, $47.12 \%$ người được khảo sát ở thôn có PFES và $44.01 \%$ ở thôn không có PFES trả lời là mức thu nhập hiện tại không đáp ứng được nhu câu của họ. 33.89 - 42.63\% hộ cho rằng chỉ tạm đủ và chỉ có 12.27 - 16.52\% cho rằng nhu cầu của họ được đáp ứng đây đủ. Không có sự chênh lệch quá lớn giữa kết quả trả lời của nhóm tham gia PFES với nhóm không tham gia PFES (Hình 1).

Các hộ cũng nêu ra lý do mà nhu cầu của họ chưa được đáp ứng. Phổ biến nhất, được $66 \%$ hộ nêu ra là tình trạng thiếu việc làm dẫn đến thu nhập thấp, không ổn định, không đủ trang trải chi phí sinh hoạt trong khi giá cả càng ngày càng đắt đỏ và thời tiết không thuận lợi. 46\% hộ cũng đề cập đến vấn đề thiếu đất sản xuất, đất đai bạc màu, diện tích nhỏ và không có vốn để đâu tư vào sản xuất nông nghiệp. Hai nhu cầu tiếp theo cũng rất cấp thiết là có rất nhiều người được phỏng vấn và gia đình của họ có sức khỏe kém, hay đau ốm nên cần nhiều tiền để khám chữa bệnh và rất nhiêu hộ đông con nên cân tiền cho con ăn học. Với thu nhập thấp, việc trả nợ ngân hàng và các khoản nợ khác cũng là một thách thức rất lớn cho các hộ.

Ngoài những lý do phổ biến trên, một số hộ còn nhắc tới vấn đề tiền $\mathrm{PFES}$ được chi trả cho cộng đông chứ không phải cá nhân nên thu nhập của họ không thực sự tăng. Các hoạt động sinh kế truyền thống như phát rẫy, khai thác lâm sản hiện đã bị cấm, rừng lại ở xa nên phân thu nhập từ rừng rất hạn chế. Một số hộ mong muốn được Nhà nước trợ cấp và có nước để sản xuất.

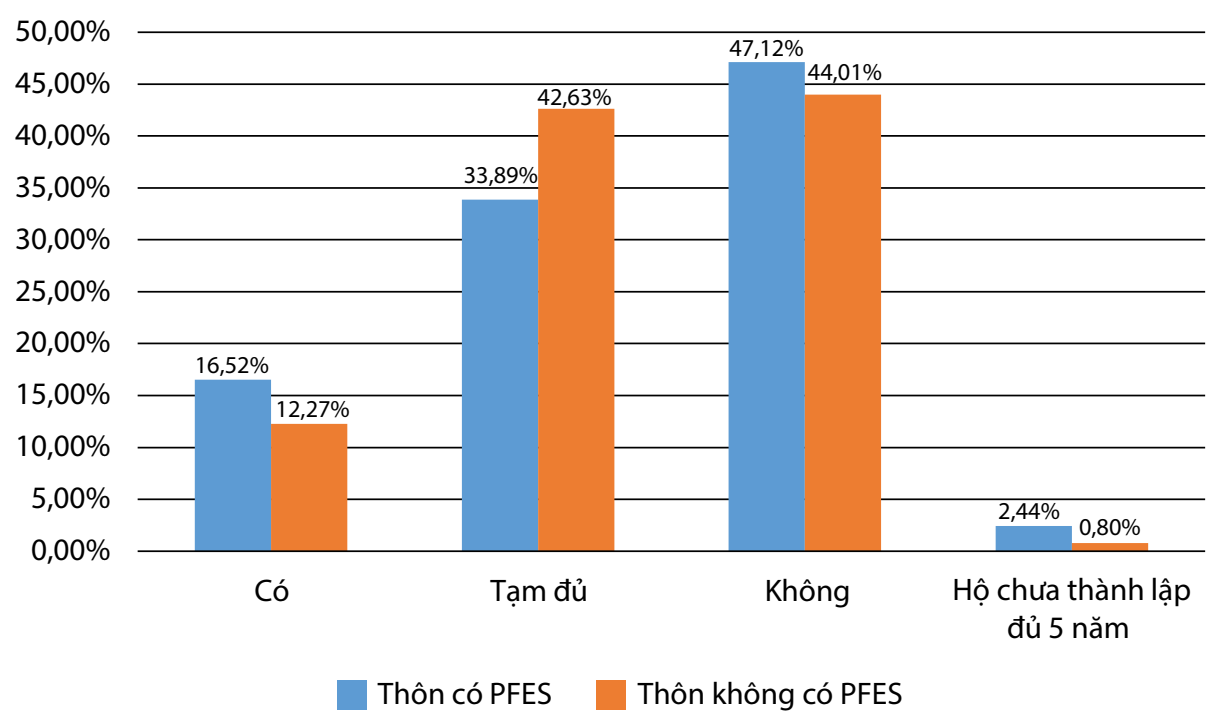

Hình 1. Mức độ đáp ứng của thu nhập đối với nhu cầu đời sống

Nguồn: Tổng hợp kết quả khảo sát, 2020 


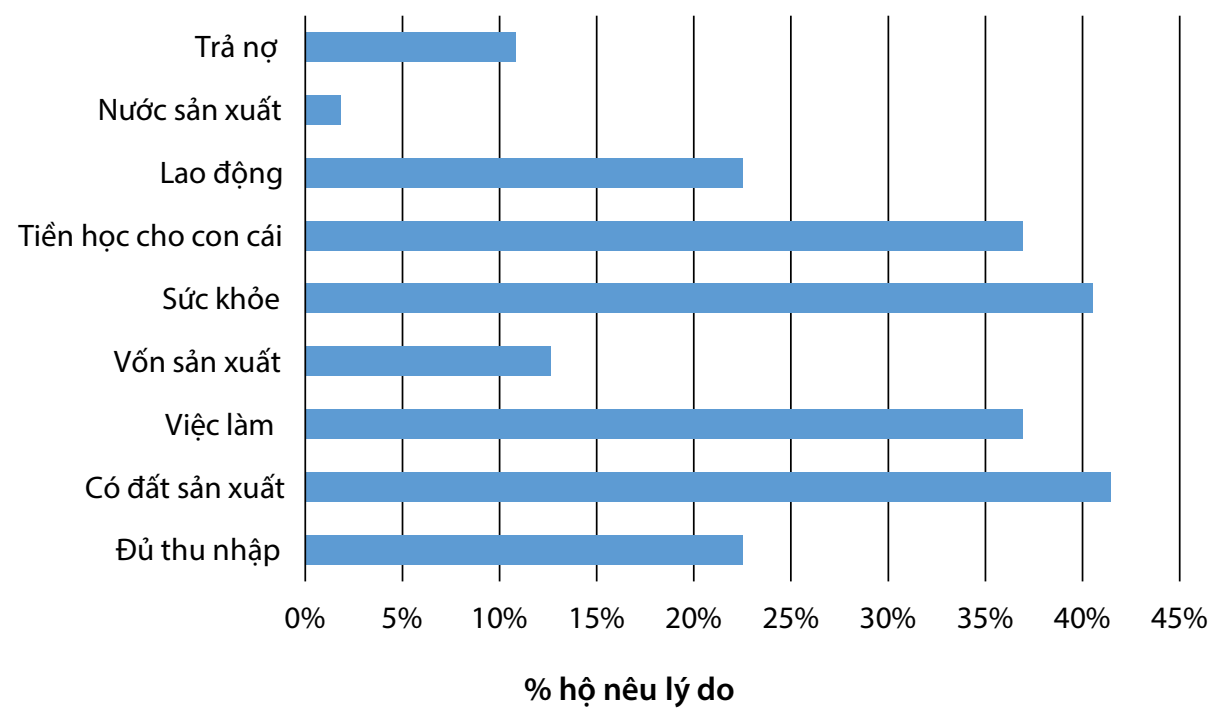

Hình 2. Lý do các hộ khảo sát nêu ra khi thu nhập không đáp ứng nhu cầu

Nguồn: Tổng hợp kết quả khảo sát, 2020

Nhìn chung, hâu hết các hộ nghèo tại địa bàn khảo sát đều có thu nhập rất thấp, không ổn định (trung bình khoảng 2 - 3 triệu đông/tháng). Thu nhập của nhiêu hộ phụ thuộc khá lớn vào làm thuê (vác keo, bóc vỏ keo và phụ hô). Với diện tích đất trồng trọt hạn chế và đất xấu, người dân không thể có nguồn thu nhập lớn từ hoạt động này. Bên cạnh đó, hoạt động chăn nuôi tại địa phương nói chung và ở các hộ tham gia thảo luận nhóm nói riêng chỉ ở mức nhỏ lẻ hoặc hộ không chăn nuôi do không có vốn để mua con giống. Qua khảo sát cho thấy rằng, rất nhiều hộ muốn tham gia vào hoạt động chăn nuôi vì nguồn thu mà hoạt động này mang rất đáng kể nếu không có dịch bệnh hay sự cố nào xảy ra. Đó là lí do tại sao đâu tư vào hoạt động chăn nuôi được xem là chiến lược sinh kế hàng đầu của hộ trong các bước thoát nghèo (Bảng 6). Hầu hết các hộ đều sử dụng số tiền khoảng 1 - 1,5 triệu để mua giống vật nuôi có giá thành rẻ như gà, vịt. Mua giống dê, giống heo là chiến lược thoát nghèo tiếp theo của các hộ nếu họ có từ 3 - 4 triệu đồng và xây mới hoặc sửa sang chuông trại với số tiền từ $6-8$ triệu đồng. Theo ý kiến của nhiều hộ, khi họ có khả năng mua được giống trâu, bò (số tiền từ 10 12 triệu đông) thì được xem là đã thoát nghèo. Như đã nói ở trên các hộ thuộc diện nghèo đa số không có hoạt động chăn nuôi do không có vốn để đầu tư hoặc có nuôi nhửng con giống là do nhà nước hoặc các dự án hỗ trợ. Vì vậy, khi hộ có khả năng tự mua con giống và đa dạng hóa hoạt động chăn nuôi được xem là đã thoát nghèo là nhận định phù hợp với tình hình thực tế của các hộ nghèo tại địa bàn khảo sát.
Qua các cuộc thảo luận cũng cho thấy rằng, khi các hộ có điều kiện để xây hoặc sửa nhà (trước kia là nhà tạm bợ hoặc ở chung), mua các vật dụng trong gia đình, mua các phương tiện phục vụ cho sản xuất thì được xem là có mức sống trung bình. Mua đất và mua giống cây để phát triển hoạt động trông trọt (trông keo, cây ăn quả), gửi tiền tiết kiệm và đầu tư cho con cái học hành là chiến lược được nhiều hộ lựa chọn khi mức sống của họ đạt ở mức khá giả trở lên.

Thông tin liên quan đến mục đích sử dụng tiền từ PFES cũng nhận ghi nhận trong quá trình thực hiện phương pháp này. Thực tế cho thấy rằng có một số hộ sử dụng tiền chi trả để mua giống vật nuôi có giá thành rẻ như gà, vịt hoặc mua giống keo. Tuy nhiên, mục đích sử dụng này không phổ biến ở các hộ vì số tiền nhận được không nhiều (trung bình từ 1,2 - 1,5 triệu đồng/năm) và thường nhận vào dịp gần tết Nguyên Đán nên được sử dụng vào việc mua lương thực, thực phẩm và tiêu dùng ngày tết chứ không phục vụ cho các hoạt động tạo thu nhập.

\subsection{Tác động của PFES đối với xóa đói giảm nghèo tại địa phương}

Theo báo cáo của UBND các xã, tỷ lệ hộ nghèo theo chuẩn nghèo quốc gia ở các xã khảo sát khá cao, có những xã hơn $40 \%$ hộ là hộ nghèo

Kết quả phỏng vấn hộ cũng cho thấy trong nhóm khảo sát, tỷ lệ hộ nghèo và cận nghèo ở cả 2 
Bảng 6. Các bước thoát nghèo của cộng đồng (tổng hợp của tất cả các thôn nghiên cứu)

\begin{tabular}{cl}
\hline Bước & Chiến lược \\
\hline 10 & Gửi tiết kiệm, đầu tư cho con cái học hành \\
\hline 9 & Mua thêm đất để trồng trọt \\
\hline \multicolumn{2}{l}{ Từ trung bình lên khá giả } \\
\hline 7 & Mua máy cày, máy kéo, máy bơm nước \\
\hline 6 & Tiếp tục mua thêm giống gà, heo, bò \\
\hline 5 & Thoát nghà, sửa nhà, mua các vật dụng trong gia đình \\
\hline 4 & Mua giống trâu, bò, phân bón, thức ăn chăn nuôi \\
\hline 3 & Mua giống heòm mới chuồng nuôi heo \\
\hline 2 & Mua lương thực, mua giống gà, vịt \\
\hline 1 & Thiếu đất sản xuất, không có sức lao động, không có vốn, nhà tạm bợ \\
\hline
\end{tabular}

Nguồn: Thảo luận nhóm, 2020

Bảng 7. Số hộ nghèo ở các thôn có nguồn thu nhập từ PFES

\begin{tabular}{lllccccc}
\hline STT & Xã & Tên thôn & $\begin{array}{c}\text { Tổng số } \\
\text { hộ }\end{array}$ & $\begin{array}{c}\text { Tổng số } \\
\text { hộ nghèo }\end{array}$ & $\begin{array}{c}\text { Số hộ có } \\
\text { thu nhập } \\
\text { từ PFES }\end{array}$ & $\begin{array}{c}\text { Số hộ nghèo } \\
\text { có thu nhập } \\
\text { từ PFES }\end{array}$ & $\begin{array}{c}\text { Đã thực } \\
\text { hiện PFES } \\
\text { chưa? }\end{array}$ \\
\hline 1 & Hồng Vân & Ta Lo A Hố & 170 & 39 & 0 & 0 & Không \\
\hline 2 & Hồng Trung & A Niêng Lê Triêng 1 & 200 & 89 & 0 & 0 & Không \\
\hline 3 & Hồng Trung & Ta Ay Ta & 200 & 87 & 0 & 0 & Không \\
\hline 4 & Nhâm & Âr Kêu Nhâm & 78 & 30 & 0 & 0 & Không \\
\hline 5 & Bắc Sơn & A Đeeng-Par Lieng 1 & 160 & 39 & 29 & 15 & Có \\
\hline 6 & Bắc Sơn & A Đeeng Par Lieng 2 & 165 & 58 & 27 & 16 & Có \\
\hline 7 & Nhâm & A Hươr Pa E & 68 & 31 & 28 & 12 & Có \\
\hline 8 & Hồng Trung & Đụt Lê Triêng 2 & 176 & 72 & 59 & 19 & Có \\
\hline 9 & Hương Phong & Hương Phú & 115 & 1 & 106 & 1 & Có \\
\hline 10 & Nhâm & Kleng- A Bung & 152 & 40 & 76 & 19 & Có \\
\hline 11 & Hồng Hạ & Pa Ring- Cân Sâm & 131 & 20 & 84 & 11 & Có \\
\hline 12 & Hồng Kim & A Tia 1 & 108 & 19 & 24 & 7 & Có \\
\hline
\end{tabular}

Nguồn: Tổng hợp kết quả khảo sát, 2020

nhóm tham gia và không tham gia PFES đều rất lớn. Tại thôn tham gia PFES, 51.26\% hộ khảo sát là hộ nghèo và cận nghèo. Tại thôn không tham gia PFES, 54.92\% hộ khảo sát là nghèo và cận nghèo. Tỷ lệ hộ nghèo tại các thôn tham gia PFES thấp hơn $11.21 \%$ so với thôn không tham gia PFES. Khi so sánh bắt cặp, trong cùng một xã Nhâm, thôn Âr Kêu Nhâm không tham gia PFES có tỷ lệ hộ nghèo lên tới 33.33\% nhưng thôn $\mathrm{A}$ Hươr $\mathrm{Pa} \mathrm{E}$ có tham gia PFES tỷ lệ hộ nghèo chỉ là $10 \%$.
Tuy nhiên, khái niệm về loại hộ nghèo, khá, trung bình hay giàu được hiểu theo nhiều cách khác nhau, phụ thuộc vào từng đối tượng, quan điểm và tình hình thực tế tại mỗi địa phương (Bảng 8) Do đó, việc đưa ra các tiêu chí phân loại hộ thường chỉ dừng lại ở mức tương đối và rất khó lượng hóa, dẫn đến những khó khăn bất cập trong quá trình đánh giá và phân loại. Để tìm hiểu quan điểm vể hộ giàu, hộ nghèo cũng như các tiêu chí để xác định các loại hộ đó từ góc nhìn của người dân, các buổi thảo luận nhóm đã 
Bảng 8. Tiêu chí phân loại hộ do cộng đồng xác định tại thôn Ta Lo A Hố và A Đeeng Par Lieng 1 (có PFES) huyện A Lưới

\begin{tabular}{|c|c|c|c|c|c|c|}
\hline \multirow[t]{2}{*}{ Tiêu chí } & \multicolumn{2}{|c|}{ Hộ nghèo } & \multicolumn{2}{|c|}{ Hộ trung bình } & \multicolumn{2}{|c|}{ Hộ khá } \\
\hline & Ta Lo A Hố & $\begin{array}{l}\text { A Đeeng Par } \\
\text { Lieng } 1\end{array}$ & Ta Lo A Hố & $\begin{array}{l}\text { A Đeeng Par } \\
\text { Lieng } 1\end{array}$ & Ta Lo A Hố & $\begin{array}{c}\text { A Đeeng } \\
\text { Par Lieng } 1\end{array}$ \\
\hline Thu nhập & $\begin{array}{l}\text { Thu nhập không } \\
\text { ổn định, dưới } 2.5 \\
\text { triệu đồng/tháng }\end{array}$ & $\begin{array}{l}\text { Thu nhập từ } \\
1 \text { - } 1.5 \text { triệu } \\
\text { đồng/tháng, } \\
\text { thu nhập bấp } \\
\text { bênh }\end{array}$ & $\begin{array}{l}\text { Thu nhập từ } 2.5 \\
\text {-3.5 triệu đồng/ } \\
\text { tháng }\end{array}$ & $\begin{array}{l}\text { Thu nhập } \\
\text { từ } 3 \text { - } 4 \text { triệu } \\
\text { đồng/tháng }\end{array}$ & $\begin{array}{l}\text { Thu nhập từ } \\
3 \text { triệu đồng } \\
\text { trở lên }\end{array}$ & \\
\hline \multirow[t]{2}{*}{ Tài sản } & $\begin{array}{l}\text { Nhà ở không kiên } \\
\text { cố, nền đất, mái } \\
\text { lợp bằng tranh tre } \\
\text { hoặc nhà do nhà } \\
\text { nước cấp, hoặc } \\
\text { nhà nước hồ trợ } \\
\text { một phần kinh phí } \\
\text { đề xây. }\end{array}$ & $\begin{array}{l}\text { Nhà ở tạm bợ, } \\
\text { dùng tranh tre } \\
\text { để dựng nhà, } \\
\text { nền đất } \\
\text { Không có ti vi, } \\
\text { xe máy. }\end{array}$ & $\begin{array}{l}\text { Nhà ở tự xây } \\
\text { kiên cố, hoặc } \\
\text { được nhà nước } \\
\text { hỗ trợ một phần } \\
\text { và hộ tự bỏ } \\
\text { thêm tiền để } \\
\text { xây dựng được } \\
\text { nhà kiên cố. }\end{array}$ & $\begin{array}{l}\text { Nhà ở tương } \\
\text { đối kiên cố, } \\
\text { xây bằng xi } \\
\text { măng, gạch. } \\
\text { Có xe máy giá } \\
\text { trị từ } 5 \text { triệu - } \\
7 \text { triệu (mua } \\
\text { xe cũ), ti vi giá } \\
\text { trị từ } 1.5 \text { - } 2 \\
\text { triệu }\end{array}$ & $\begin{array}{l}\text { Nhà ở kiên } \\
\text { cố, tự xây } \\
\text { Có xe máy } \\
\text { trên } 10 \text { triệu } \\
\text { đồng }\end{array}$ & \\
\hline & $\begin{array}{l}\text { Có xe máy giá trị } \\
\text { dưới } 7 \text { triệu đồng, } \\
\text { Ti vi có giá trị } \\
\text { khoảng } 1.5 \text { triệu } \\
\text { đồng }\end{array}$ & & $\begin{array}{l}\text { Có xe máy giá } \\
\text { trị từ } 10 \text { - } 15 \\
\text { triẹ̣u, Ti vi có giá } \\
\text { trị khoảng } 2 \text { - } 3 \\
\text { triệu đồng }\end{array}$ & & & \\
\hline $\begin{array}{l}\text { Đất sản } \\
\text { xuất }\end{array}$ & $\begin{array}{l}\text { Diện tích đất } \\
\text { nông nghiệp: } 0.05 \\
\text { - } 0.1 \text { ha, diện tích } \\
\text { đất lâm nghiệp } \\
\text { (trồng keo): từ } 1 \text { - } \\
1.5 \text { ha, đất không } \\
\text { tốt và xa nên khó } \\
\text { trồng keo và giá } \\
\text { bán keo thấp }\end{array}$ & $\begin{array}{l}\text { Diện tích đất } \\
\text { nông nghiệp } \\
\text { từ } 0.15-0.2 \\
\text { ha, diện tích } \\
\text { đất trồng keo } \\
\text { khoảng } 0.05 \text { ha }\end{array}$ & $\begin{array}{l}\text { Diện tích đất } \\
\text { nông nghiệp } \\
\text { từ } 0.1-0.15 \\
\text { ha, diện tích } \\
\text { đất lâm nghiệp } \\
\text { (trồng keo): từ } \\
1.5 \text { - } 2 \text { ha }\end{array}$ & $\begin{array}{l}\text { Diện tích đất } \\
\text { nông nghiệp } \\
\text { khoảng } 0.25 \\
\text { ha, diện tích } \\
\text { dất trồng keo } \\
\text { khoảng } 0.5 \text { ha }\end{array}$ & $\begin{array}{l}\text { Diện tích đất } \\
\text { lâm nghiệp } \\
\text { từ } 3 \text { - } 4 \text { ha }\end{array}$ & \\
\hline Giáo dục & $\begin{array}{l}\text { Không có khả } \\
\text { năng cho con đi } \\
\text { học } \\
\text { Con cái nghỉ học } \\
\text { sớm để phụ giúp } \\
\text { gia đình (học hết } \\
\text { cấp } 1 \text { đến giữa } \\
\text { cấp 2) }\end{array}$ & $\begin{array}{l}\text { Con học đến } \\
\text { cấp } 1\end{array}$ & $\begin{array}{l}\text { Có khả năng } \\
\text { cho con học đến } \\
\text { lớp } 12\end{array}$ & $\begin{array}{l}\text { Con học đến } \\
\text { cấp } 3\end{array}$ & $\begin{array}{l}\text { Có khả năng } \\
\text { cho con học } \\
\text { trên lớp } 12\end{array}$ & \\
\hline Sức khỏe & & $\begin{array}{l}\text { Sức khỏe } \\
\text { không tốt } \\
\text { để làm việc, } \\
\text { thường xuyên } \\
\text { đau ốm }\end{array}$ & & $\begin{array}{l}\text { Đủ sức khỏe } \\
\text { để làm việc }\end{array}$ & & \\
\hline
\end{tabular}

Nguồn: Thảo luận nhóm, 2020

được tổ chức tại các thôn có tham gia PFES và thôn không tham gia vào $\mathrm{PFES}$. Kết quả thu được cho thấy người dân chủ yếu dựa vào những tiêu chí sau để phân loại hộ: Thu nhập, tài sản, đất sản xuất (gồm đất trông màu và đất trông keo), hoạt động chăn nuôi và giáo dục. Một số thôn khác có thêm các tiêu chí như sức khỏe (khả năng lao động của các thành viên trong hộ) và tiếp cận dịch vụ. Sự khác nhau trong nội dung của từng tiêu chí đối với từng loại hộ đã phản ánh được khả năng 


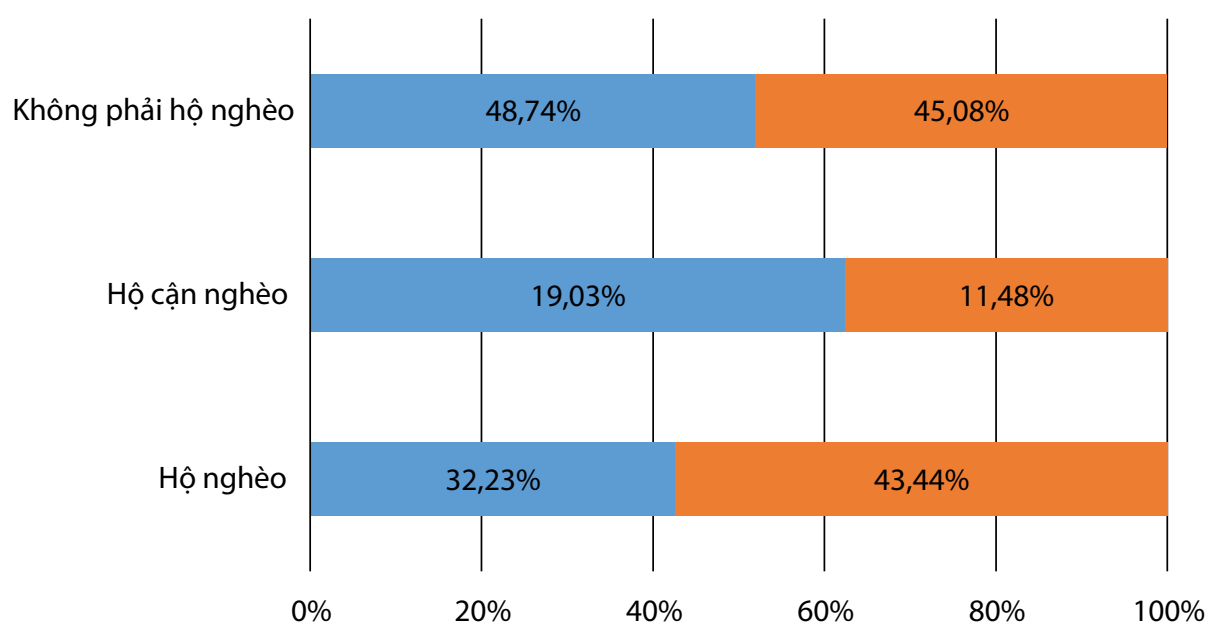

Thôn có PFES Thôn không có PFES

Hình 3. Thu nhập phân theo kinh tế hộ

Nguồn: Tổng hợp kết quả khảo sát, 2020

quan sát và nhận định của người dân về thực tế đời sống của cộng đông.

\subsection{PFES và tiếp cân tài nguyên để thúc đẩy sinh kế bền vững.}

Sử dụng khung sinh kế bền vững, nhóm nghiên cứu lần lượt đánh giá tác động của PFES đối với 5 nguồn vốn: tài nguyên, vật chất, tài chính, con người, và xã hội.

\subsubsection{Tiếp cận tài nguyên đất đai}

Đất đai có vai trò đặc biệt quan trọng đối với hộ gia đình, đặc biệt khi hoạt động sinh kế của hộ phụ thuộc vào khu vực nông nghiệp. Tính trung bình, diện tích đất mà các hộ tham gia khảo sát được sử dụng tương đối nhỏ cho cả hai nhóm tham gia và không tham gia PFES. Với thôn tham gia PFES, diện tích đất trung bình sau khi PFES ra đời chỉ là 1.19 ha/hộ. Với thôn không có PFES, diện tích đất trung bình sau năm 2014 là 1.73 ha/ hộ. Sau khi PFES có hiệu lực, diện tích đất bình quân đầu người có giảm nhẹ ở các thôn trong cả hai nhóm tham gia và không tham gia PFES.

Với diện tích đất nhỏ như vậy, các hộ đã dành một tỷ lệ lớn cho mục đích trông cây lâm nghiệp. Trước và sau thời điểm có chính sách PFES, các hộ tham gia PFES đều dành trung bình khoảng $69.42 \%$ diện tích đất họ có cho việc trông cây lâm nghiệp, $24.45 \%$ cho trồng cây nông nghiệp còn lại là phần diện tích đất ở và chăn nuôi rất nhỏ. Đối với các hộ không tham gia PFES, đất trông cây lâm nghiệp cũng có diện tích lớn nhất rôi đến đất trông cây nông nghiệp, đất ở và những mục đích sử dụng khác. Tuy nhiên, đối với các hộ này, sau khi chính sách PFES ra đời, tuy họ không tham gia PFES nhưng tỷ lệ đất dành cho mục đích lâm nghiệp trung bình đã tăng lên $1.23 \%$ so với thời điểm trước khi có PFES. Nếu so sánh giữa thôn có $\mathrm{PFES}$ và không có $\mathrm{PFES}$ theo tỷ lệ trung bình thì các hộ không tham gia PFES đều dành tỷ lệ phần trăm đất cho mục đích lâm nghiệp cao hơn các hộ tham gia PFES ngay cả trước và sau thời điểm có $\mathrm{PFES}$ với mức chênh lệch trước thời điểm PFES ra đời là $5.74 \%$ và sau thời điểm PFES là $6 \%$.

Nếu xét theo tỷ lệ phân trăm thì đất của các hộ được dùng chủ yếu để trông cây lâm nghiệp nhưng theo số tuyệt đối thì diện tích đất trồng cây lâm nghiệp của các hộ trong cả hai nhóm đêu rất nhỏ. Trung bình nhóm tham gia PFES có 0.87 ha/hộ để trông cây lâm nghiệp còn con số này cho nhóm không tham gia PFES là 1.42 ha/hộ.

Về tính pháp lý, hơn 70\% diện tích đất của các hộ khảo sát đến từ cả hai nhóm đều có giấy chứng nhận quyền sử dụng đất, không có sự chênh lệch quá lớn giữa hộ tham gia PFES hay không tham gia cũng như trước và sau thời điểm PFES ra đời.

Khi so sánh bắt cặp thì các hộ tham gia PFES có diện tích đất trung bình hộ cao hơn các hộ ở thôn đối chứng không có PFES ở cả thời điểm trước và sau khi PFES ra đời. Ví dụ như trong 
Bảng 9. Diện tích và cơ cấu sử dụng đất của các nhóm hộ khảo sát

\begin{tabular}{|c|c|c|c|c|c|c|}
\hline \multirow[t]{3}{*}{ Chỉ tiêu } & \multicolumn{3}{|c|}{ Thôn có PFES } & \multicolumn{3}{|c|}{ Thôn không có PFES } \\
\hline & \multicolumn{2}{|c|}{ Trung bình } & \multirow[t]{2}{*}{ So sánh } & \multicolumn{2}{|c|}{ Trung bình } & \multirow[t]{2}{*}{ So sánh } \\
\hline & $\begin{array}{l}\text { Trước } \\
\text { PFES }\end{array}$ & Sau PFES & & $\begin{array}{l}\text { Trước } \\
\text { PFES }\end{array}$ & Sau PFES & \\
\hline Diện tích bình quân (ha/hộ) & 1.13 & 1.19 & 0.06 & 1.59 & 1.73 & 0.14 \\
\hline \multicolumn{7}{|l|}{ Theo mục đích sử dụng } \\
\hline Đất ở (\%) & 5.20 & 5.37 & 0.17 & 5.43 & 5.23 & -0.2 \\
\hline Đất trồng cây nông nghiệp (\%) & 24.90 & 23.99 & -0.91 & 17.11 & 16.52 & -0.59 \\
\hline Đất trồng cây lâm nghiệp (\%) & 68.93 & 69.90 & 0.97 & 74.67 & 75.90 & 1.23 \\
\hline Đất chăn nuôi (\%) & 0.65 & 0.50 & -0.15 & 0.00 & 0.00 & 0.00 \\
\hline Đất nuôi trồng thủy sản (\%) & 0.32 & 0.25 & -0.07 & 2.80 & 2.35 & -0.45 \\
\hline \multicolumn{7}{|l|}{ Tính pháp lý } \\
\hline Có giấy chứng nhân (\%) & 74.61 & 74.98 & 0.37 & 77.55 & 79.31 & 1.76 \\
\hline Không có giấy chứng nhận (\%) & 25.39 & 25.02 & -0.37 & 22.45 & 20.69 & -1.76 \\
\hline
\end{tabular}

Nguồn: Tổng hợp kết quả khảo sát, 2020

cùng xã Hồng Trung, các hộ được khảo sát tại thôn Đụt Lê Triêng 2 (có tham gia PFES) có diện tích đất trung bình là 1.96 ha/hộ (trước và sau khi có PFES) nhưng tại thôn A Niêng Lê Triêng 1 (không tham gia PFES), các hộ chỉ có diện tích đất trung bình là $1.55-1.68 \mathrm{ha} / \mathrm{h}$ ọ.

Đất của các hộ được dùng chủ yếu để trồng cây lâm nghiệp nhưng diện tích đất trông thực tế của các hộ trong cả hai nhóm đều rất nhỏ. Trong các thôn có hưởng lợi từ PFES, diện tích đất lâm nghiệp trung bình hộ của thôn cao nhất là 1.76 ha/hộ (thôn Đụt Lê Triêng 2), thôn thấp nhất chỉ là $0.36 \mathrm{ha} /$ hộ (A Hươr $\mathrm{Pa} \mathrm{E}$ ). Trong nhóm thôn không hưởng lợi từ PFES, sau thời điểm năm 2014 khi PFES được đưa vào thực tiễn, diện tích đất lâm nghiệp trung bình hộ của thôn cao nhất là 2.45 ha/hộ (Ta Lo A Hố), thôn thấp nhất là 0.32 ha/hộ (Âr Kêu Nhâm).

Về tính pháp lý, sau khi PFES ra đời, có sự tăng nhẹ trong tỷ lệ đất có chứng nhận quyền sử dụng đất trong tất cả các thôn khảo sát (cả tham gia và không tham gia PFES). So sánh các cặp đối chứng trong cùng một xã cho thấy tỷ lệ có giấy chứng nhận quyền sử dụng đất của các hộ tham gia PFES cao hơn hộ không tham gia PFES cả trước và sau khi PFES ra đời.

Trung bình còn khoảng $25.02 \%$ diện tích đất của các hộ tham gia PFES và $20.69 \%$ diện tích đất của hộ không tham gia PFES là chưa có giấy chứng nhận quyền sử dụng đất. Phân lớn phân diện tích này đang được các hộ sử dụng (trung bình 0.21 ha/hộ), chỉ một tỷ lệ nhỏ do gia đình thuê mướn (trung bình 0.05 ha/hộ) hoặc dùng chung với hộ khác (trung bình 0.08 ha/hộ).

\subsubsection{Tài sản vật chất}

Về tài sản của hộ ngoài rừng, các nhóm tài sản khác nhau đã được khảo sát bao gồm nhà ở, phương tiện giao thông, điện tử gia dụng và vật dụng sản xuất và được so sánh giữa thời điểm trước và sau PFES. Kết quả khảo sát cho thấy giá trị trung bình tài sản ngoài rừng của các hộ đã tăng sau khi PFES ra đời đối với cả hai nhóm hộ tham gia và không tham gia PFES, trong khoảng 21.89 - 23.79 triệu đồng/hộ. Trong đó, các hộ tham gia PFES có tài sản giá trị trung bình cao hơn hộ không tham gia.

Về nhà ở: Tỷ lệ hộ có nhà ở trong thôn đều tăng cho cả hai nhóm tham gia và không tham gia PFES sau thời điểm năm 2014 và 100\% hộ đều có nhà ở trong thôn ở các thôn có PFES và $99.19 \%$ hộ có nhà trong thôn của các thôn không có PFES. Có 2.5\% hộ khảo sát ở thôn PFES có thêm nhà ở ngoài thôn trong khi không có hộ nào ở thôn đối chứng có nhà ở ngoài thôn.

Phương tiện giao thông: Về phương tiện giao thông, các hộ được yêu câu chia sẻ thông tin về số lượng và giá trị các phương tiện bao gồm ô tô, xe tải, xe máy, xe đạp, xe điện và thuyền/bè trước và sau thời điểm PFES ra đời. Khi tính tỷ lệ hộ có 
Bảng 10. Tỷ lệ sở hữu nhà của các nhóm hộ khảo sát

\begin{tabular}{|c|c|c|c|c|c|c|}
\hline \multirow[t]{3}{*}{ Chỉ tiêu } & \multicolumn{3}{|c|}{ Thôn có PFES } & \multicolumn{3}{|c|}{ Thôn không có PFES } \\
\hline & \multicolumn{2}{|c|}{ Trung bình } & \multirow[t]{2}{*}{ So sánh } & \multicolumn{2}{|c|}{ Trung bình } & \multirow[t]{2}{*}{ So sánh } \\
\hline & Trước PFES & Sau PFES & & Trước PFES & Sau PFES & \\
\hline $\begin{array}{l}\text { Sở hữu nhà trong } \\
\text { thôn (\%) }\end{array}$ & 95.86 & 100 & 4.14 & 95.11 & 99.19 & 4.08 \\
\hline $\begin{array}{l}\text { Sở hữu nhà ngoài } \\
\text { thôn (\%) }\end{array}$ & 1.67 & 2.50 & 0.83 & 0 & 0 & 0 \\
\hline
\end{tabular}

Nguồn: Số liệu thu thập của nhóm tác giả, năm 2020

một trong các phương tiện nêu trên, có thể thấy sau năm 2014, tại tất cả các thôn cả tham gia và không tham gia PFES đều có số lượng phương tiện tăng lên đáng kể so với trước khi có PFES. Tại thôn tham gia PFES, trước khi chính sách này được thực thi, chỉ có trung bình $48.60 \%$ hộ có các phương tiện giao thông được khảo sát nhưng sau năm 2014, tỷ lệ này tăng lên hơn 1.5 lần, thành $72.64 \%$ hộ có. Tại thôn không tham gia PFES, tỷ lệ hộ có phương tiện giao thông trước 2014 thấp hơn tại các thôn tham gia PFES nhưng sau thời điểm này, mức độ tăng phương tiện trung bình lại tăng gấp hai lần với $81.08 \%$, cao hơn tỷ lệ trung bình sau PFES của các thôn tham gia PFES. So sánh bắt cặp cũng cho thấy xu hướng này.

Các thôn không tham gia PFES ban đầu có ít phương tiện giao thông hơn thôn tham gia PFES nhưng sau thời điểm PFES được thực hiện thì mức độ tăng lại lớn hơn. Ví dụ như thôn $\mathrm{A}$ Niêng Lê Triêng 1 (không tham gia PFES), trước PFES chỉ có $38.71 \%$ hộ có một trong các loại phương tiện được khảo sát thì sau PFES, con số này lên tới $90.32 \%$, gấp hơn hai lần. Trong khi đó thôn đối chứng có tham gia PFES, cùng một xã Hông Trung là Đụt Lê Triêng 2, có 67.74\% hộ có các phương tiện giao thông được khảo sát, cao hơn A Niêng Lê Triêng 1 trước PFES nhưng sau PFES, tỷ lệ này tuy có tăng lên nhưng chỉ ở mức 83.87\%, thấp hơn A Niêng Lê Triêng 1 .

Giá trị của các phương tiện cũng được các hộ chia sẻ và dựa theo giá trị trung bình của các phương tiện thì sau PFES, các hộ sở hữu những phương tiện có giá trị hơn (cả tham gia và không tham gia PFES) với giá trị bình quân tất cả các phương tiện là 11.46 triệu đông/hộ ở thôn có PFES và 10.77 triệu đông/hộ ở thôn không có PFES. Khi tính cơ cấu giá trị của các loại phương tiện, thì tỷ lệ các phương tiện từ 5 - 20 triệu đồng và trên 20 triệu đông sau PFES cũng tăng lên cho cả hai nhóm. Ví dụ như tại các thôn có PFES, trước 2014, chỉ có $23.79 \%$ phương tiện có giá trị từ 5- 20 triệu đồng thì sau PFES con số này lên tới $29.65 \%$. Tại các thôn không có PFES, trước 2014 các phương tiện có giá trị trên 20 triệu đông chiếm 6.55\%, sau PFES đã tăng lên đạt $14.62 \%$ phương tiện có giá trị cao. Tuy nhiên ở cả 2 nhóm dù trước hay sau PFES, tỷ lệ những loại phương tiện rẻ tiền, cũ dưới 5 triệu vẫn chiếm đa số ở mức $70.43 \%$ (trước PFES) và $50.57 \%$ (sau PFES) cho nhóm tham gia PFES và $76.27 \%$ (trước PFES), 47.66\% (sauPFES) cho nhóm không tham gia PFES.

Xe máy là loại phương tiện giao thông phổ biến nhất, chiếm $68 \%$ tổng số phương tiện (sau PFES) của tất cả 243 hộ tham gia khảo sát. Nếu trước khi PFES ra đời, chỉ có $36 \%$ hộ có xe máy với giá trị trung bình rất thấp 4.6 triệu/chiếc thì sau PFES con số này tăng lên $70 \%$, giá trị trung bình của xe cũng tăng lên 10.01 triệu/xe. So sánh giữa thôn tham gia $\mathrm{PFES}$ và không tham gia $\mathrm{PFES}$ thì các hộ ở thôn tham gia PFES có xe máy có giá trị trung bình cao hơn thôn không tham gia PFES cả trước và sau năm 2014 ở mức 5.1 triệu đồng/ chiếc trước $\mathrm{PFES}$ và 10.4 triệu đông/chiếc sau PFES. Con số này ở thôn không tham gia PFES chỉ là 4.1 triệu đồng/chiếc trước $P F E S$ và 9.7 triệu đông/chiếc sau PFES.

Điện tử gia dụng: Về điện tử gia dụng, các sản phẩm sau được đưa vào khảo sát: máy phát điện/ năng lượng mặt trời, điện thoại di động/điện thoại bàn, Tivi/Ăngten/Chảo vệ tinh, loa, đài, đầu đọc đĩa, máy tính, máy khâu, máy cưa, tủ lạnh, bếp ga, nôi cơm điện và máy giặt. Theo kết quả khảo sát, trong những sản phẩm trên, những sản phẩm mà đa phân các hộ đều có là điện thoại di động (77\%), tivi (71\%), nôi cơm điện (56\%) và bếp ga (44\%). 
Bảng 11. Giá trị phương tiện hoặc tài sản các nhóm hộ khảo sát

\begin{tabular}{|c|c|c|c|c|c|c|}
\hline \multirow[t]{3}{*}{ Chỉ tiêu } & \multicolumn{3}{|c|}{ Thôn có PFES } & \multicolumn{3}{|c|}{ Thôn không có PFES } \\
\hline & \multicolumn{2}{|c|}{ Trung bình } & \multirow{2}{*}{$\begin{array}{l}\text { Chênh } \\
\text { lệch }\end{array}$} & \multicolumn{2}{|c|}{ Trung bình } & \multirow{2}{*}{$\begin{array}{l}\text { Chênh } \\
\text { lệch }\end{array}$} \\
\hline & Trước PFES & Sau PFES & & Trước PFES & Sau PFES & \\
\hline \multicolumn{7}{|l|}{ Phương tiện giao thông } \\
\hline Tỷ lệ hộ có (\%) & $48.60 \%$ & $72.64 \%$ & $24.04 \%$ & $39.25 \%$ & $81.08 \%$ & $41.83 \%$ \\
\hline Giá trị bình quân (tr.đ/hộ) & 5.32 & 11.46 & 6.14 & 4.27 & 10.77 & 6.5 \\
\hline \multicolumn{7}{|l|}{ Cơ cấu quy mô giá trị (\%) } \\
\hline Dưới 5 & 70.43 & 50.57 & -19.86 & 76.27 & 47.66 & -28.61 \\
\hline Từ 5 đến 20 & 23.79 & 29.65 & 5.86 & 17.18 & 37.72 & 20.54 \\
\hline Trên 20 & 5.78 & 19.79 & 14.01 & 6.55 & 14.62 & 8.07 \\
\hline \multicolumn{7}{|l|}{ Điện tử gia dụng } \\
\hline Tỷ lệ hộ có (\%) & $50.27 \%$ & $95.03 \%$ & $44.76 \%$ & $40.21 \%$ & $95.08 \%$ & $54.87 \%$ \\
\hline Giá trị bình quân (tr.đ/hộ) & 1.55 & 6.47 & 4.92 & 1.13 & 4.94 & 3.81 \\
\hline \multicolumn{7}{|l|}{ Cơ cấu quy mô giá trị (\%) } \\
\hline Dưới 5 & 89.38 & 65.35 & -24.03 & 93.41 & 63.18 & -30.23 \\
\hline Từ 5 đến 10 & 8.15 & 18.15 & 10.00 & 4.92 & 24.53 & 19.61 \\
\hline Trên 10 & 2.48 & 16.51 & 14.03 & 1.67 & 12.29 & 10.62 \\
\hline \multicolumn{7}{|l|}{ Vật dụng sản xuất } \\
\hline Tỷ lệ hộ có (\%) & $3.28 \%$ & $3.28 \%$ & $0 \%$ & $2.47 \%$ & $11.53 \%$ & 8.88 \\
\hline Giá trị bình quân (tr.đ/hộ) & 0.38 & 0.29 & -0.09 & 0.11 & 0.35 & 0.24 \\
\hline \multicolumn{7}{|l|}{ Cơ cấu quy mô giá trị (\%) } \\
\hline Dưới 5 & 99.19 & 99.19 & 0.00 & 99.19 & 99.19 & 0.00 \\
\hline Từ 5 đến 30 & 0.00 & 0.00 & 0.00 & 0.81 & 0.00 & -0.81 \\
\hline Trên 30 & 0.81 & 0.81 & 0.00 & 0.00 & 0.81 & 0.81 \\
\hline Tổng giá trị vật dụng (tr.đ/hộ) & 7.25 & 18.21 & 10.96 & 5.50 & 16.06 & 10.56 \\
\hline
\end{tabular}

Nguồn: Số liệu thu thập của nhóm tác giả, năm 2020

Cũng giống như đối với phương tiện giao thông, trước PFES, tỷ lệ các hộ có đồ điện tử gia dụng ở các thôn có PFES cao hơn các thôn không có PFES tuy nhiên tỷ lệ này đã tăng lên đáng kể sau thời điểm năm 2014 tại cả hai nhóm hộ. Tại các thôn có PFES, tỷ lệ hộ có đồ điện tử gia dụng đã tăng từ 50.27\% lên 95.03\% sau khi có PFES (gấp 1.9 lần) còn tại thôn không tham gia PFES, mức độ tăng còn lớn hơn, gấp hơn 2 lần từ $40.21 \%$ lên $95.08 \%$. Giá trị bình quân các đô điện tử này cũng tăng lên sau thời điểm PFES ra đời, ở mức 6.47 triệu đông/hộ đối với hộ có tham gia PFES và 4.94 triệu đồng/hộ đối với hộ không tham gia PFES. Nếu trước khi có PFES, $89.38 \%$ đô điện tử các hộ sở hữu có giá trị dưới 5 triệu đông thì sau PFES, tỷ lệ các sản phẩm có giá trị cao hơn 5 triệu đã tăng lên đáng kể. Đặc biệt tỷ lệ sở hữu đô điện tử trên 10 triệu sau PFES cao hơn gấp
2-4 lần so với trước khi có PFES, từ 2.48\% lên $16.51 \%$ tại các hộ tham gia PFES và từ $1.67 \%$ đến 12.29\% đối với hộ không tham gia PFES.

Kết quả so sánh bắt cặp cũng cho thấy xu hướng tương tự của việc giá trị và số lượng đồ điện tử gia dụng các hộ có sau khi PFES ra đời tăng lên ở cả hai nhóm. Ngoài ra, so sánh bắt cặp còn cho thấy sau PFES, các hộ tham gia PFES sở hữu đồ gia dụng có giá trị cao hơn các hộ không tham gia. Ví dụ như các hộ ở thôn A Đeeng Par Lieng 2 (có tham gia PFES) sở hữu đô điện tử có giá trị trung bình là 7.95 triệu đồng/hộ thì thôn đối chứng Ta Ay Ta, các hộ chỉ dành trung bình 4.94 triệu đông/hộ để mua đồ gia dụng. Tỷ lệ các hộ có đồ điện tử trên 10 triệu đồng ở thôn Đụt Lê Triêng 2 (có tham gia PFES) là $19.35 \%$ trong khi thôn A Niêng Lê Triêng 1 (không tham gia PFES) chỉ là $9.68 \%$. 

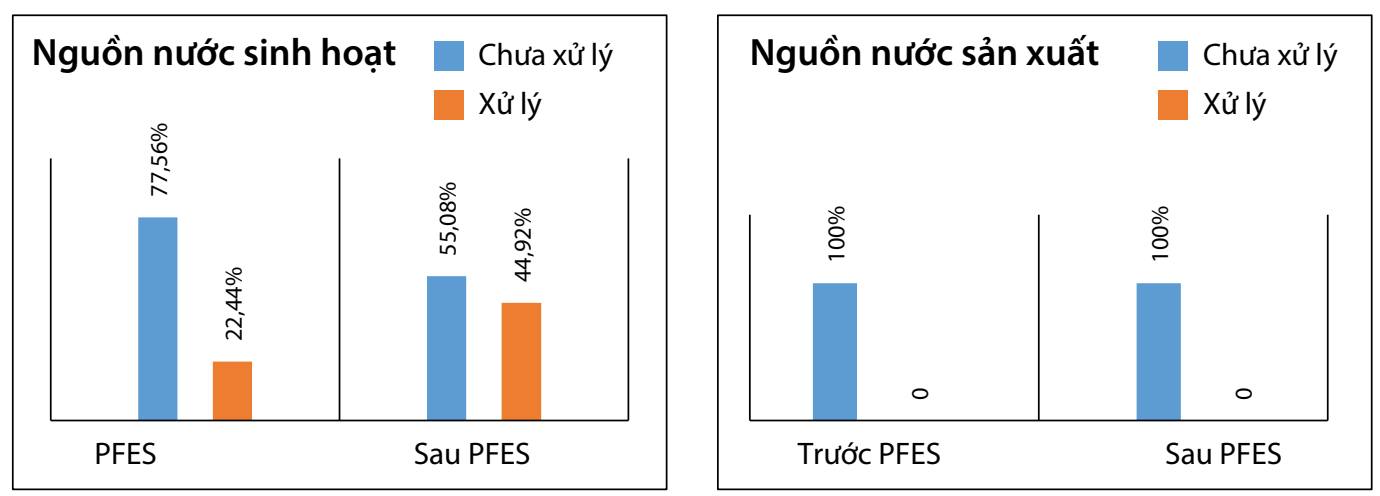

Thôn có PFES
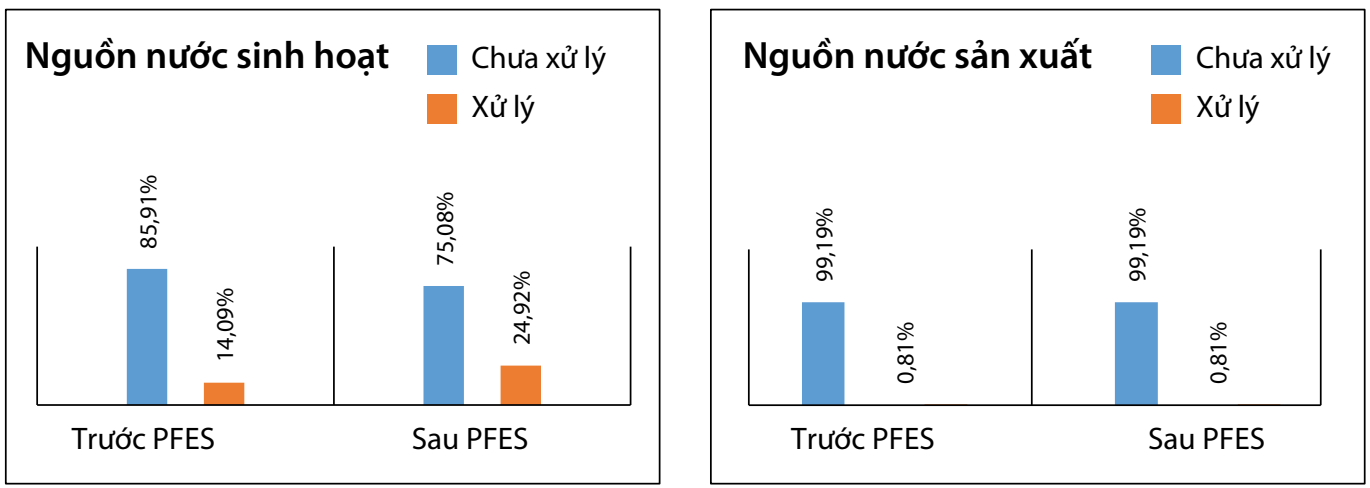

Thôn không có PFES

Hình 4. Nguồn nước sinh hoạt và sản xuất của nhóm hộ điều tra

Nguồn số liệu: Số liệu thu thập của nhóm tác giả, năm 2020

Vật dụng sản xuất nông nghiệp: Về vật dụng sản xuất, có rất ít hộ có những vật dụng được liệt kê. Loại vật dụng có nhiều hộ nhắc tới nhất là máy phun thuốc với 14 hộ (6\% hộ khảo sát), 3 hộ có máy bơm nước và 1 hộ có máy cắt cỏ. Số hộ có máy phun thuốc có tăng từ 6 hộ lên 14 hộ sau PFES nhưng do mẫu nhỏ nên không thấy sự khác biệt rõ ràng giữa các cặp so sánh.

Tiếp cận sử dụng nước, điện và vật liệu đun nấu của hộ: Nước, điện và vật liệu đun nấu là những dịch vụ cơ bản mà người dân cân được tiếp cận và phản ánh điều kiện sống của người dân địa phương. Về nguồn nước, các hộ tham gia khảo sát đã được hỏi về nguôn nước họ đang sử dụng cho mục đích sinh hoạt và sản xuất là nước đã được xử lý chưa. Nước được xử lý là nước từ nhà máy còn nước sông, ao, hồ, suối, nước giếng là chưa được xử lý. Kết quả khảo sát cho thấy hơn 99\% nước sản xuất của các hộ thuộc cả hai nhóm tham gia và không tham gia PFES đều là nguồn nước chưa xử lý. Trước và sau khi PFES ra đời, tỷ lệ này không có sự thay đổi nhiều.
Một tỷ lệ rất lớn nước sinh hoạt các hộ đang sử dụng là chưa xử lý nhưng tỷ lệ này có chiều hướng giảm xuống theo thời gian. Tại thôn không có PFES, trước 2014, trung bình có tới $85.91 \%$ hộ sử dụng nước sinh hoạt chưa qua xử lý nhửng sau thời điểm này tỷ lệ này giảm xuống còn $75.08 \%$ nhưng vẫn còn cao và cao hơn tỷ lệ này ở các thôn tham gia PFES. Tại các thôn có tham gia PFES, trước 2014, trung bình chỉ có $22.44 \%$ hộ sử dụng nước máy cho sinh hoạt nhửng sau thời điểm PFES ra đời, tỷ lệ này đã tăng lên $44.92 \%$. Khi so sánh con số giữa các thôn, nếu các thôn trong cùng một xã thì không thấy rõ sự khác biệt lớn giữa thôn tham gia PFES và không tham gia PFES về việc tiếp cận nguôn nước. Tỷ lệ hộ sử dụng nước máy cho sinh hoạt tương đối thấp ở các thôn như Đụt Lê Triêng 2 (có tham gia PFES), tỷ lệ sử dụng nước có xử lý cho sinh hoạt sau PFES dù có tăng so với trước PFES nhưng vẫn chỉ là $9.68 \%$. Chỉ có hai thôn $\mathrm{A}$ Hươr $\mathrm{Pa} E$ và Âr Kêu Nhâm của xã Nhâm là có hơn $85 \%$ các hộ được sử dụng nước máy cho sinh hoạt và thôn $\mathrm{A}$ Đeeng Par Lieng 1, A Đeeng Par 
Bảng 12. Sử dụng điện của nhóm hộ điều tra

\begin{tabular}{|c|c|c|c|c|c|c|}
\hline \multirow[t]{3}{*}{ Chỉ tiêu } & \multicolumn{3}{|c|}{ Thôn có PFES } & \multicolumn{3}{|c|}{ Thôn không có PFES } \\
\hline & \multicolumn{2}{|c|}{ Trung bình } & \multirow[t]{2}{*}{ Chênh lệch } & \multicolumn{2}{|c|}{ Trung bình } & \multirow[t]{2}{*}{ Chênh lệch } \\
\hline & Trước PFES & Sau PFES & & Trước PFES & Sau PFES & \\
\hline Không sử dụng điện (\%) & 0.00 & 0.00 & 0.00 & 0.81 & 0.00 & -0.81 \\
\hline Có nhưng miễn phí (\%) & 0.00 & 0.00 & 0.00 & 0.00 & 0.83 & 0.83 \\
\hline Điện lưới trả phí (\%) & 100.00 & 100.00 & 0.00 & 99.19 & 99.17 & -0.02 \\
\hline Máy phát riêng (\%) & 0.00 & 0.00 & 0.00 & 0.00 & 0.00 & 0.00 \\
\hline Khác (\%) & 0 & 0 & 0 & 0 & 0 & 0 \\
\hline
\end{tabular}

Nguồn: Tổng hợp từ kết quả khảo sát, 2020

Bảng 13. Sử dụng vật liệu đun nấu của nhóm hộ điều tra

\begin{tabular}{|c|c|c|c|c|c|c|}
\hline \multirow[t]{3}{*}{ Chỉ tiêu } & \multicolumn{3}{|c|}{ Thôn có PFES } & \multicolumn{3}{|c|}{ Thôn không có PFES } \\
\hline & \multicolumn{2}{|c|}{ Trung bình } & \multirow[t]{2}{*}{ Chênh lệch } & \multicolumn{2}{|c|}{ Trung bình } & \multirow[t]{2}{*}{ Chênh lệch } \\
\hline & Trước PFES & Sau PFES & & Trước PFES & Sau PFES & \\
\hline Gỗ củi & 79.69 & 51.67 & -28.02 & 86.41 & 53.36 & -33.05 \\
\hline Thực vật & 2.44 & 1.21 & -1.23 & 3.29 & 1.72 & -1.57 \\
\hline Than & 0.57 & 0.38 & -0.19 & 0.00 & 0.00 & 0.00 \\
\hline Gas & 6.36 & 23.66 & 17.3 & 3.37 & 22.99 & 19.62 \\
\hline Điện & 10.94 & 23.10 & 12.16 & 6.94 & 21.93 & 14.99 \\
\hline
\end{tabular}

Nguồn: Tổng hợp từ kết quả khảo sát, 2020

Lieng 2 thuộc xã Bắc Sơn có khoảng 25-45\% hộ có nước máy.

Về tiếp cận điện, $100 \%$ các hộ khảo sát đều có sử dụng điện lưới và phải trả phí ở thôn có PFES trước và sau khi có PFES. Ở các thôn không có PFES trước khi có PFES có 99.19\% hộ sử dụng điện lưới trả phí, sau khi có PFES tỉ lệ này đã giảm xuống chỉ còn $99.17 \%$ hộ dân sử dụng điện lưới trả phí. Điều này minh chứng cho tỷ lệ điện khí hóa nông thôn cao tại Việt Nam.

Về vật liệu đun nấu, các hộ sử dụng nhiều loại vật liệu và một hộ cùng một lúc cũng sử dụng nhiều vật liệu khác nhau. Phổ biến nhất là củi, bếp ga và bếp điện trong đó gỗ củi được nhiều hộ sử dụng nhất. Tuy nhiên tỷ lệ hộ sử dụng củi có giảm theo thời gian trong khi tỷ lệ sử dụng ga và điện tăng lên đáng kể. Như tại các thôn tham gia PFES, trước PFES, trung bình có 79.69\% hộ đun củi thì sau PFES, tỷ lệ này chỉ còn $51.67 \%$. Ngược lại, nếu trước PFES, chỉ có 6.36\% hộ dùng bếp ga thì sau PFES, con số này tăng lên gần 4 lân thành $23.66 \%$, tỷ lệ dùng bếp điện cũng tăng hơn 2 lần từ $10.94 \%$ lên đến $23.10 \%$. Tại các thôn không có PFES, xu hướng giảm đốt củi, tăng sử dụng ga và bếp điện cũng được thể hiện rõ, thậm chí mức chênh lệch trước và sau PFES còn lớn hơn khi tỷ lệ bếp ga tăng từ $3.37 \%$ trước PFES lên thành $22.99 \%$ sau PFES và tỷ lệ sử dụng củi giảm từ $86.41 \%$ xuống còn $53.36 \%$.

Một tỷ lệ nhỏ các hộ có sử dụng thực vật để đun nấu nhưng số này giảm đáng kể sau khi có PFES ở cả hai nhóm. Nếu trước khi có PFES, tỷ lệ hộ đun nấu bằng thực vật ở nhóm tham gia và không tham gia PFES lần lượt là $2.44 \%$ hộ và $3.29 \%$ thì sau PFES con số này giảm hơn hai lần xuống còn $1.21 \%$ và $1.72 \%$. 


\section{Tác động kinh tế}

Nguôn kinh phí của PFES có một vai trò quan trọng và thiết yếu đối với các đơn vị chủ rừng tham gia vào công tác quản lý, bảo vệ rừng. Nguôn kinh phí này giúp cho các đơn vị chủ rừng là các tổ chức nhà nước, cộng đông, nhóm hộ, hộ gia đình đảm bảo được nguồn kinh phí để thực hiện tốt các hoạt động BV\&QLR. Từ năm 2014 -2019, tổng số tiền PFES chi cho chủ rừng là hơn 177.12 tỷ đồng, trong đó số tiền chi cho các chủ rừng cao nhất vào năm 2019 là hơn 48.76 tỷ đông và thấp nhất vào năm bắt đầu triển khai chi trả cho chủ rừng (2014) là 11.28 tỷ đông. Số tiên PFES đã giải ngân bình quân trong giai đoạn này là 29.52 tỷ đồng/năm.

Theo đại diện của Quỹ Bảo vệ và Phát Triển Rừng tỉnh Thừa Thiên Huế cho biết "Dự án khác thì chỉ thực hiện có giai đoạn ngắn, thành quả dự án là ít, PFES mang tính ổn định lâu dài. Dự án nước ngoài yêu câu phải có vốn đối ứng cho mọi hoạt động và do vậy người dân sử dụng tiền PFES để làm vốn đối ứng tạo điều kiện để có dự án mới”.

Trong các phần dưới đây, nhóm tác giả sẽ tập trung thảo luận tác động của PFES đối với quy mô hộ gia đình.

\subsection{Thu nhập của hộ nghiên cứu}

Bảng 14 cho thấy tình hình lao động và việc làm trên địa bàn nghiên cứu. Có thể thấy số lượng hộ gia đình có thu nhập ổn định tại điểm có PFES và không có $\mathrm{PFES}$ đều rất thấp và tuy tỉ lệ lao động có thu nhập ổn định ở thôn có PFES cao hơn so với thông không có PFES, sự chênh lệch này không nhiêu.

Khi so sánh đặc điểm chủ hộ, sự khác biệt giữa hai nhóm tham gia và không tham gia PFES trong hâuu hết các tiêu chí là tương đối nhỏ (dưới $10 \%$ ). Tính trung bình, $90.91 \%$ người được khảo sát ở nhóm tham gia PFES và $88.55 \%$ người của nhóm không tham gia PFES đều đến từ các gia đình có chủ hộ là nam và chủ hộ trong độ tuổi từ 30 - 50. Tỷ lệ chủ hộ có lương ổn định khá thấp, trung bình chỉ $10.70 \%$ ở nhóm có tham gia PFES và $5.75 \%$ ở thôn không tham gia PFES. Một số ít chủ hộ đi làm thuê, đã già yếu hoặc chỉ ở nhà. Còn lại đều làm nghề nông là chủ yếu (trung bình $72.82 \%$ ở thôn có PFES và $79.44 \%$ ở thôn không có PFES).

\subsubsection{Thu nhập từ rừng}

Để nghiên cứu tác động của PFES tới sinh kế các hộ, thu nhập từ rù̀ng và ngoài rừng của hộ đã được khảo sát chi tiết. Theo đó, vê gỗ rừng tự nhiên, trước PFES chỉ có 3 hộ (1 hộ thuộc thôn có $\mathrm{PFES}$ và 2 hộ thuộc thôn không PFES) chia sẻ là họ có khai thác từ rừng nhưng sau PFES, cả 3 hộ này đều không còn khai thác.

Về lâm sản ngoài gỗ, các loại lâm sản có hộ khai thác bao gồm tre nứa, mây, củi, cây thuốc, động vật làm thuốc, măng, mật ong, ếch đá, ốc đá. Trong các loại này, chỉ có củi là có nhiều hộ khai

Bảng 14. Tình hình lao động ở địa bàn nghiên cứu

\begin{tabular}{|c|c|c|c|c|}
\hline & \multirow[t]{2}{*}{ Đơn vị tính } & Thôn có PFES & Thôn không có PFES & \multirow[t]{2}{*}{ Chênh lệch } \\
\hline & & Trung bình & Trung bình & \\
\hline Tỷ lệ lao động có thu nhập ổn định & $\%$ & 8.25 & 7.05 & 1.2 \\
\hline
\end{tabular}

Nguồn: Tổng hợp từ kết quả khảo sát, 2020 


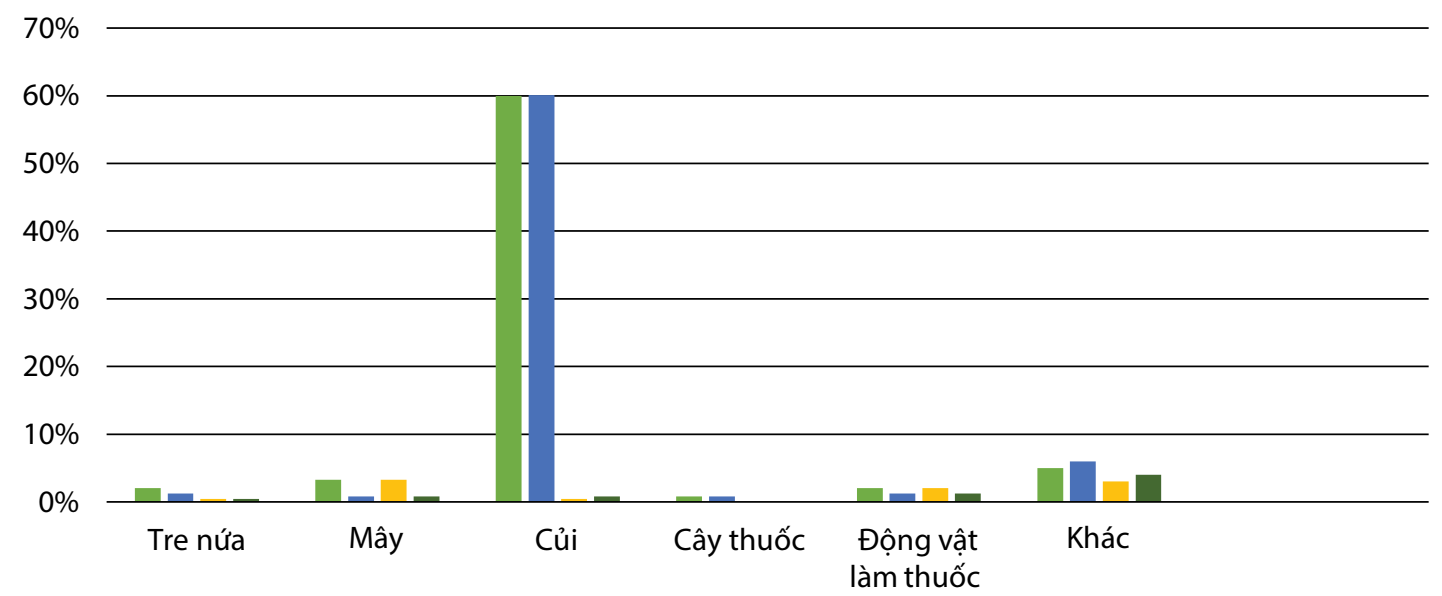

Tỷ lệ hộ khai thác trước PFES

Tỷ lệ hộ khai thác sau PFES

Tỷ lệ hộ bán trước PFES

Tỷ lệ hộ bán sau PFES

Hình 5. Tỷ lệ hộ khai thác lâm sản ngoài gỗ trước và sau PFES

Nguồn: Tổng hợp từ kết quả khảo sát, 2020
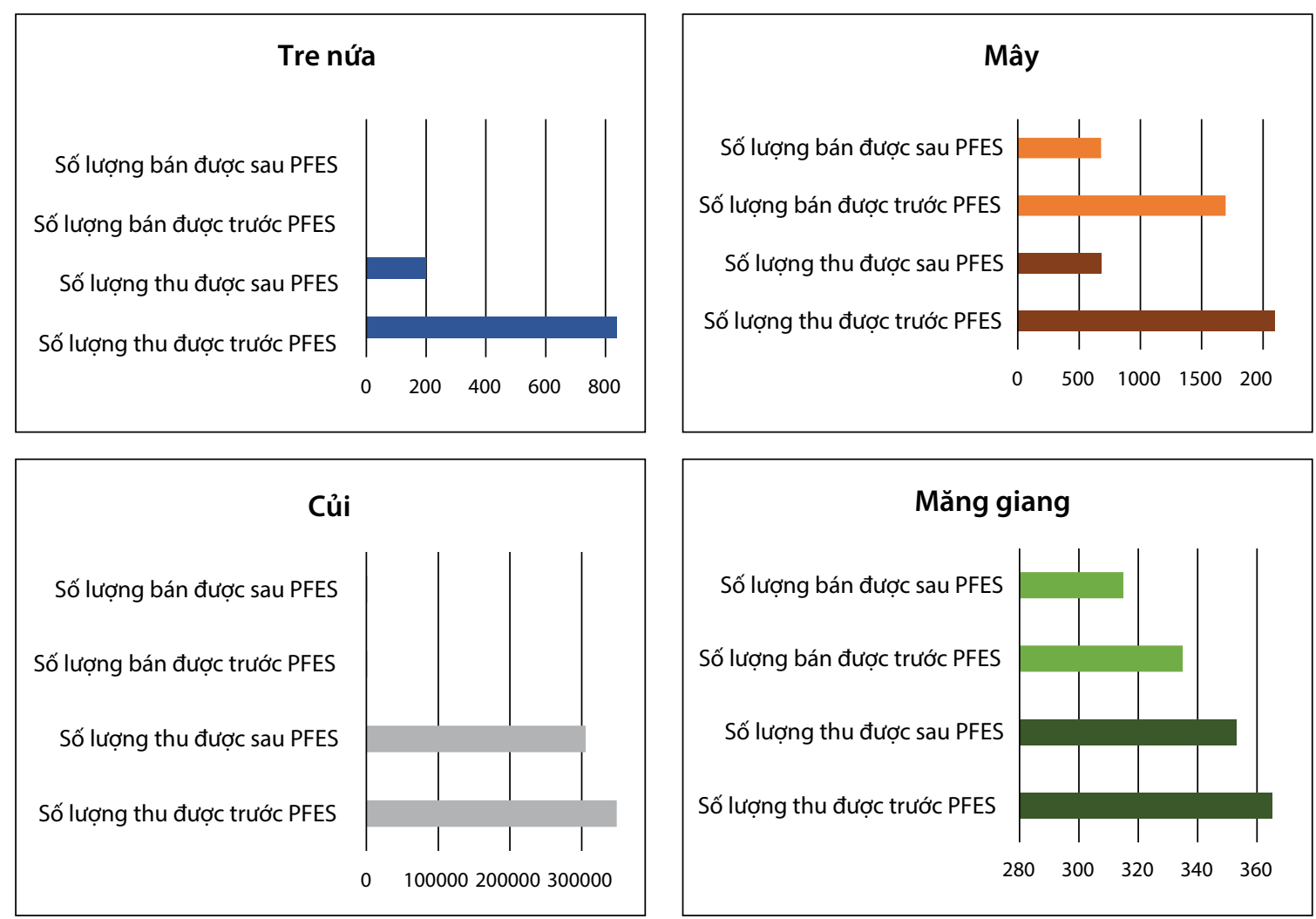

Hình 6. Sản lượng khai thác và bán lâm sản ngoài gỗ trước và sau PFES của các hộ khảo sát Nguồn: Tổng hợp từ kết quả khảo sát, 2020

thác nhất, $60 \%$ hộ trước PFES và sau PFES. Các loại còn lại, số lượng hộ tham gia khai thác rất ít trước PFES và sau PFES còn ít hơn nữa. Việc khai thác của các hộ chỉ phục vụ cho mục đích sử dụng của gia đình là chính, có rất ít hộ chia sẻ là họ có bán lâm sản ra bên ngoài, chỉ $2 \%$ trước khi 
có PFES và $1 \%$ sau khi có PFES nhưng chỉ đối với mây, củi và động vật làm thuốc. Các lâm sản còn lại đều không có ghi nhận là hộ có bán.

Về sản lượng thu được đối với các loại lâm sản ngoài gỗ chính, sản lượng thu được sau PFES thấp hơn trước PFES như tổng sản lượng tre nứa thu được của các hộ khảo sát trước PFES cao gấp 4.5 lần so với con số này sau PFES. Sản lượng bán ra thấp hơn sản lượng thu được như củi, hộ dân chỉ bán dưới $1 \%$ số lượng họ thu được. Sản lượng bán sau PFES cũng thấp hơn sản lượng bán ra trước PFES như sản lượng mây bán sau PFES đã giảm 4 lần so với trước PFES. Xu hướng này phản ánh tình trạng tài nguyên cạn kiệt và quy mô kinh tế lâm nghiệp nhỏ của địa phương.

Với sản lượng bán ra thấp, giá trị thu về từ lâm sản ngoài gỗ của các hộ cũng tương đối thấp. Trung bình các hộ chỉ thu được 526,000 đông/hộ trước PFES và 775,000 đông/hộ sau PFES từ lâm sản ngoài gỗ.

Kết quả so sánh bắt cặp không cho thấy sự khác biệt lớn giữa thôn tham gia $\mathrm{PFES}$ và thôn không tham gia PFES.

Tất cả các hộ được khảo sát cũng được hỏi nêu ý kiến của họ về tình hình sử dụng lâm sản. Không có sự khác biệt lớn giữa nhóm tham gia và không tham gia PFES. Hơn 91\% các hộ trong cả 2 nhóm đều không có thu nhập từ bán lâm sản. Các hộ còn lại thì cho rằng việc bán lâm sản của họ đang trong chiều hướng ít đi. Về tiêu dùng lâm sản, tỷ lệ hộ không có tiêu dùng lâm sản cũng rất lớn, $45.40 \%$ ở thôn có $\mathrm{PFES}$ và $48.33 \%$ ở thôn không có PFES. Trong các hộ có tiêu dùng ở cả hai nhóm tham gia và không tham gia PFES, 27.29$31.24 \%$ cho rằng họ ít sử dụng lâm sản hơn trước và $15.54-22.34 \%$ cho rằng không có sự thay đổi trong sử dụng lâm sản của hộ trước và sau khi PFES ra đời.

Các hộ cũng giải thích lý do việc tiêu dùng và buôn bán lâm sản của họ ít đi. 51\% người trả lời nêu lý do là do rất nhiều hộ giờ đã chuyển sang dùng bếp điện, bếp ga nên nhu câu dùng củi ít đi. $23 \%$ cho rằng do tài nguyên ngày càng cạn kiệt, phải đi rất xa mới có thể lấy được củi. $15 \%$ giải thích là do pháp luật cấm khai thác lâm sản và chính quyền địa phương kiểm tra chặt chẽ nên họ không vào rừng khai thác nữa. $13 \%$ nói rằng họ đã chuyển sang lấy củi từ rừng trông, cụ thể là rừng keo và tận dụng gỗ keo để đun nấu. Một số hộ bổ sung những lý do cá nhân như già yếu, không có thời gian đi xa, v.v

Có hai người được phỏng vấn tại thôn có PFES cho rằng họ khai thác lâm sản nhiêu hơn trước do họ dành nhiều thời gian hơn để vào rừng thu

Bảng 15. Tình hình sử dụng lâm sản của hộ khảo sát

\begin{tabular}{|c|c|c|c|}
\hline \multirow[t]{2}{*}{ Chỉ tiêu } & Thôn có PFES & Thôn không có PFES & \multirow[t]{2}{*}{ Chênh lệch } \\
\hline & Trung bình & Trung bình & \\
\hline \multicolumn{4}{|l|}{ Tình hình tiêu dùng lâm sản } \\
\hline + Nhiều hơn & 1.67 & 0.81 & 0.86 \\
\hline + Ngang bằng & 22.34 & 15.54 & 6.8 \\
\hline +lít hơn & 27.29 & 31.24 & -3.95 \\
\hline + Tùy từng loại sản phẩm & 1.64 & 1.64 & 0 \\
\hline + Không có thu nhập và tiêu dùng từ lâm sản & 45.40 & 48.33 & -2.93 \\
\hline + Không biết & 1.67 & 2.45 & -0.78 \\
\hline \multicolumn{4}{|l|}{ Tình hình bán lâm sản } \\
\hline + Nhiều hơn & 0.83 & 0.00 & 0.83 \\
\hline + Ngang bằng & 0.00 & 0.00 & 0.00 \\
\hline + Ít hơn & 7.50 & 7.54 & -0.04 \\
\hline + Tùy từng loại sản phẩm & 0.00 & 0.00 & 0.00 \\
\hline + Không có thu nhập và tiêu dùng từ lâm sản & 91.67 & 91.63 & 0.04 \\
\hline + Không biết & 0.00 & 0.83 & -0.83 \\
\hline
\end{tabular}

Nguồn: Tổng hợp từ kết quả khảo sát, 2020 


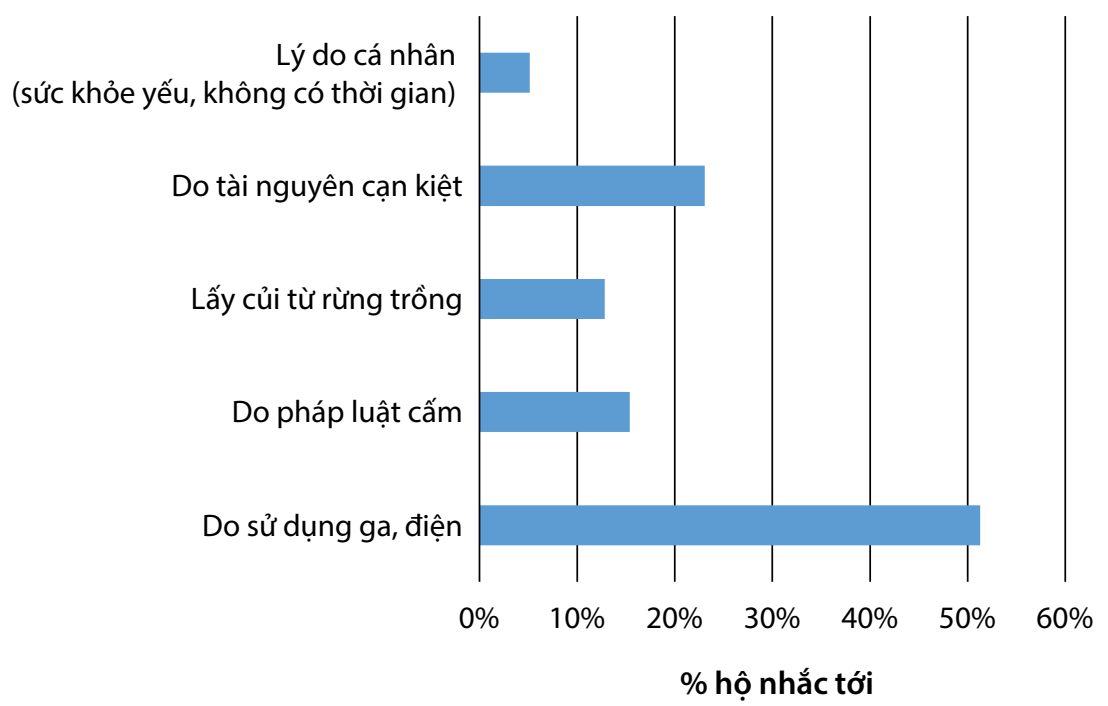

Hình 7. Lý do hộ tiêu dùng và bán lâm sản ít đi

Nguồn: Tổng hợp từ kết quả khảo sát, 2020

lượm và để đáp ứng nhu cầu thị trường về sản phẩm măng giang hiện có giá trị thị trường cao.

\subsubsection{Thu nhập của hộ từ trồng cây nông nghiệp}

Bảng 16 trình bày về thu nhập của hộ từ trông cây nông nghiệp.

Hơn $75 \%$ các hộ tham gia khảo sát đều có thu nhập từ trông cây nông nghiệp. Để khảo sát thu nhập từ trông trọt của các hộ, các hộ khảo sát được yêu câu liệt kê chi tiết sản lượng nông sản dành cho mục đích chỉ tiêu dùng và mục đích bán cũng như giá trị khi bán. Trong các nông sản thì lúa ruộng, lúa nương và khoai các hộ chỉ để ăn chứ không bán. Các sản phẩm khác như cà phê, sắn, măng, hoa quả được dùng cho mục đích bán là chính và cho sản lượng bán tăng đáng kể sau khi có PFES như sắn và cây ăn quả có sản lượng bán sau PFES tăng gấp 1.7 lần so với trước PFES. Và vì thế tổng thu nông sản sau PFES cao hơn trước thời điểm có PFES cho các hộ khảo sát trong cả hai nhóm tham gia và không tham gia PFES. Sự gia tăng trong diện tích trông sắn và cây ăn quả có thể là một vấn đề đáng lo ngại khi không còn đất bỏ hoang, một số hộ dân sẽ có xu hướng phá rừng để trông những loại cây có giá trị này.

Khi so sánh giữa thôn tham gia và không tham gia PFES, tất cả các cặp so sánh đều cho thấy tổng thu của các hộ ở thôn tham gia PFES cao hơn các hộ ở thôn không tham gia PFES. Các hộ ở thôn tham gia trung bình thu được 4.95 triệu đông/hộ từ trông trọt còn thôn không tham gia PFES chỉ là 3.61 triệu đông/hộ. Trong cùng một xã như xã Hông Trung, thôn Đụt Lê Triêng 2 (có tham gia PFES) có thu nhập trung bình sau PFES từ trông trọt là 1.54 triệu đông/hộ nhưng thôn A Niêng Lê Triêng 1 (có tham gia PFES) chỉ thu được trung bình -0.41 triệu đông/hộ.

Về chi phí trồng trọt, tính trung bình sau thời điểm PFES có hiệu lực, các hộ phải dành ra 1.38 triệu đông/hộ ở thôn có tham gia PFES và 1.52 triệu đông/hộ ở thôn không có PFES. Trong chi phí này, tiền cây giống và thuốc trừ sâu là hai khoản chiếm tỷ lệ phần trăm lớn nhất. So sánh trước và sau PFES thì chi phí cây giống của các hộ tăng từ $25 \%$ lên $31 \%$, chi phí thuốc trừ sâu giảm từ $43 \%$ xuống $25 \%$. So sánh giữa thôn không tham gia và tham gia $\mathrm{PFES}$ thì thôn tham gia PFES phải đầu tư vào trồng trọt nhiều hơn thôn không tham gia cả trước và sau năm 2014. Chi phí thuốc trừ sâu nhóm tham gia PFES bỏ ra cũng nhiêu hơn. Trong khi đó, nhóm không tham gia PFES có chi phí thuê lao động sau PFES chiếm tỷ trọng lớn hơn. Sau khi lấy tổng thu từ trông trọt trừ đi chi phí thì thu nhập từ trông trọt của các hộ trong khoảng tù 2.46 triệu đồng/ hộ cho các hộ tham gia PFES, cao hơn gấp 2 lần hộ không tham gia PFES, chỉ ở mức 0.55 triệu đồng/hộ.

Trong quá trình sản xuất, có nhiều loại nông sản các hộ phải ngừng sản xuất. Sắn, cà phê, lúa nước và lúa nương là những nông sản có nhiều hộ phải ngừng sản xuất nhất. Nguyên nhân các 
Bảng 16. Thu nhập từ trồng trọt của các nhóm hộ khảo sát

\begin{tabular}{lccccccc}
\hline \multirow{2}{*}{ Chỉ tiêu } & \multicolumn{3}{c}{ Thôn có PFES } & \multicolumn{3}{c}{ Thôn không có PFES } \\
\cline { 2 - 3 } & \multicolumn{2}{c}{ Trung bình } & Chênh lệch & \multicolumn{2}{c}{ Trung bình } & Chênh lệch \\
\cline { 2 - 3 } \cline { 5 - 6 } & Trước PFES & Sau PFES & & & Trước PFES & Sau PFES & \\
\hline Tỷ lệ hộ tham gia (\%) & 80.16 & 90.19 & 10.03 & 77.88 & 86.91 & 9.03 \\
\hline $\begin{array}{l}\text { Tổng thu từ trồng trọt/hộ } \\
\text { (triệu đông/hộ) }\end{array}$ & 3.08 & 4.95 & 1.87 & 1.70 & 3.61 & 1.91 \\
\hline $\begin{array}{l}\text { Chi phí trồng trọt/hộ (triệu } \\
\text { đông/hộ) }\end{array}$ & 0.71 & 1.38 & 0.67 & 0.73 & 1.52 & 0.79 \\
\hline $\begin{array}{l}\text { Thu nhập từ trồng trọt/hộ } \\
\text { (triệu đồng/hộ) }\end{array}$ & 2.38 & 3.58 & 1.20 & 0.97 & 2.10 & 1.13 \\
\hline
\end{tabular}

Nguồn: Tổng hợp từ kết quả khảo sát, 2020
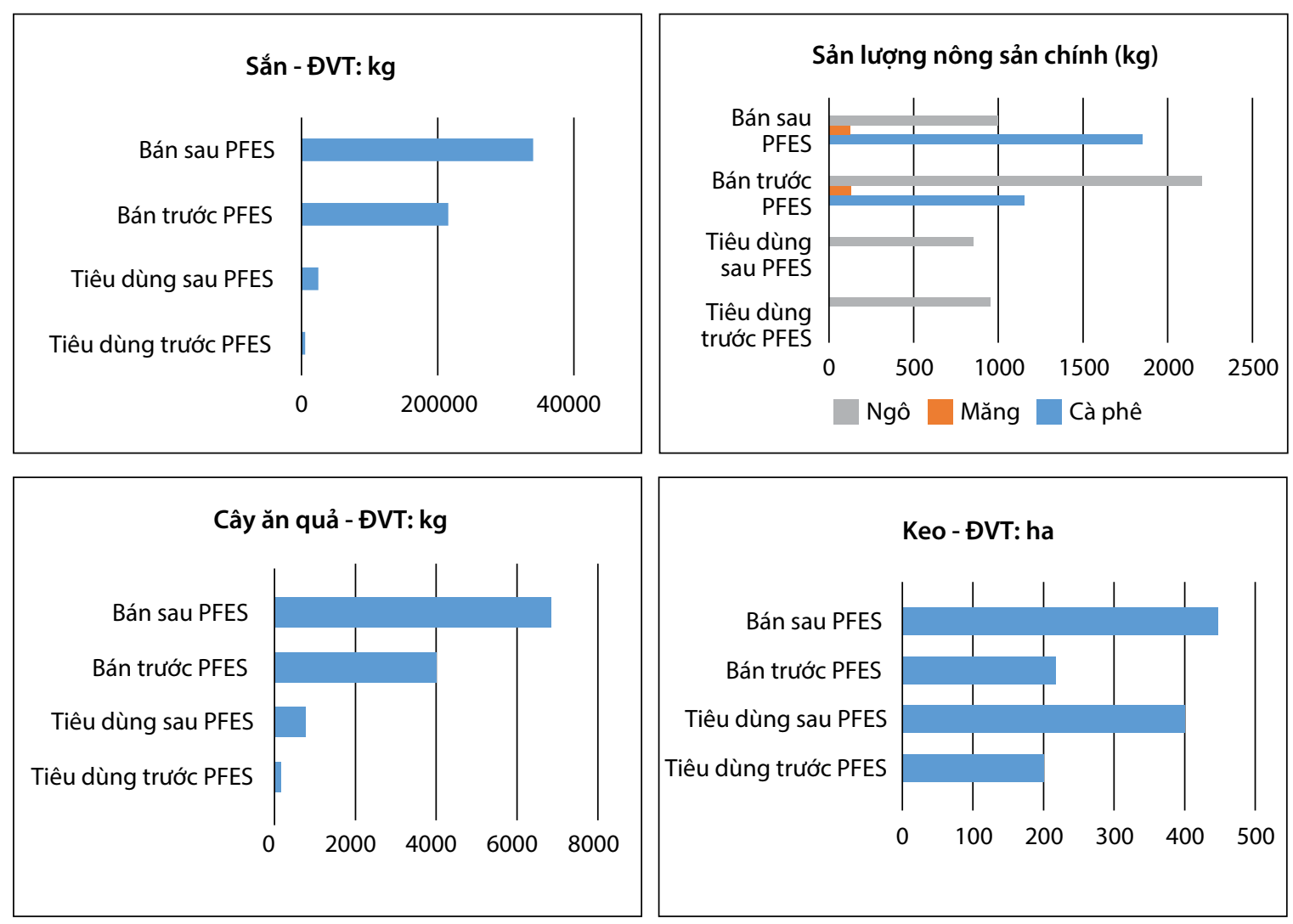

Hình 8. Sản lượng tiêu dùng và buôn bán các cây trồng chính trước và sau PFES

Nguồn: Tổng hợp từ kết quả khảo sát, 2020

hộ ngừng trồng cà phê là do nông trường cà phê phá sản nên không còn đơn vị thu mua cho các hộ. Nguyên nhân chính các hộ ngừng trồng sắn là để chuyển sang trông chuyên canh cây keo để có năng suất và giá trị kinh tế cao hơn. Đối với lúa nước và lúa nương, thiếu nước là lý do chính. Ngoài ra, việc thiếu đất canh tác sản xuất, không hợp thổ nhưỡng dẫn đến năng suất thấp cũng là những nguyên nhân được nhiều hộ nhắc tới khi quyết định chuyển đổi cây trồng.

\subsubsection{Thu nhập từ chăn nuôi}

Chăn nuôi là một hoạt động kinh tế quan trọng của các hộ gia đình khảo sát. Kết quả khảo sát cho thấy so với trước thời điểm PFES ra đời, sau PFES, tỷ lệ hộ có đầu tư vào chăn nuôi ở cả hai nhóm đêu tăng đáng kể. Ở các thôn tham gia PFES, nếu trước khi PFES ra đời chỉ có $29.65 \%$ hộ có chăn nuôi thì sau PFES tỷ lệ này tăng lên gấp hai lân là $62.02 \%$. Ở thôn không tham gia 


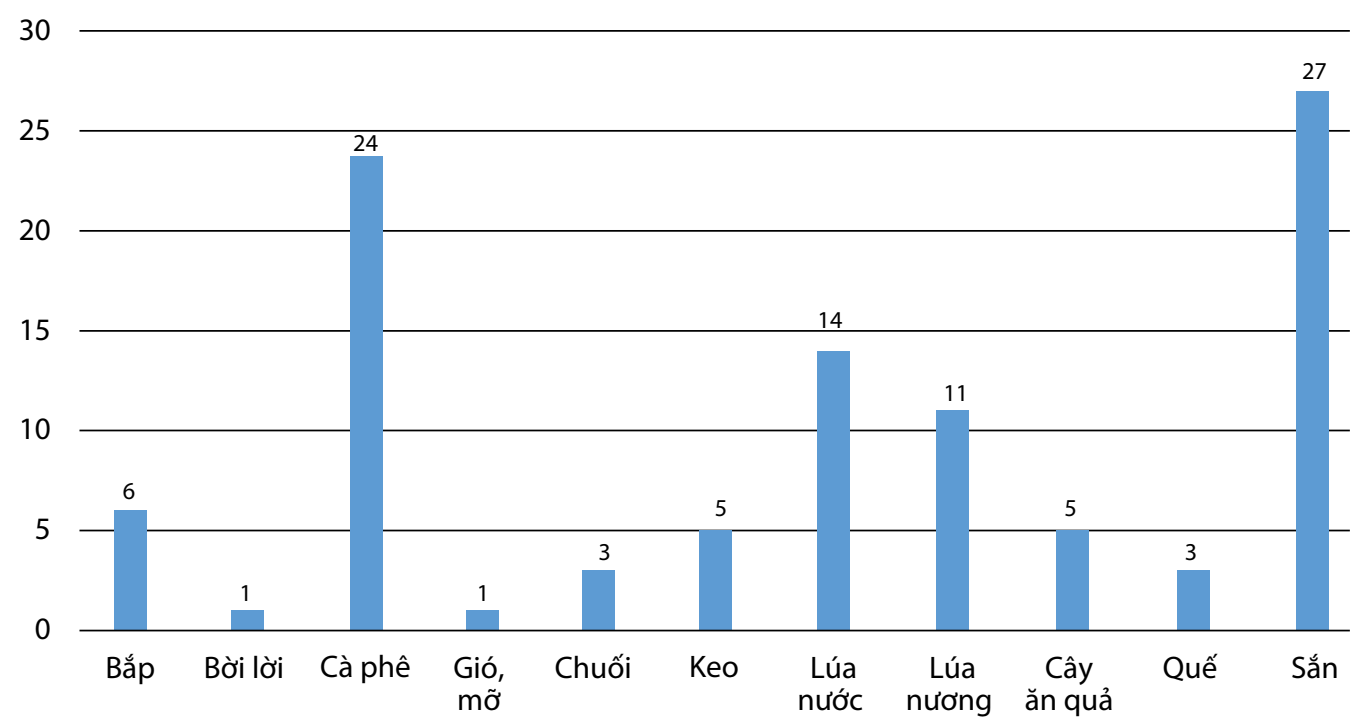

Hình 9. Số hộ và các nông sản hộ ngừng sản xuất (số hộ)

Nguồn: Tổng hợp từ kết quả khảo sát, 2020

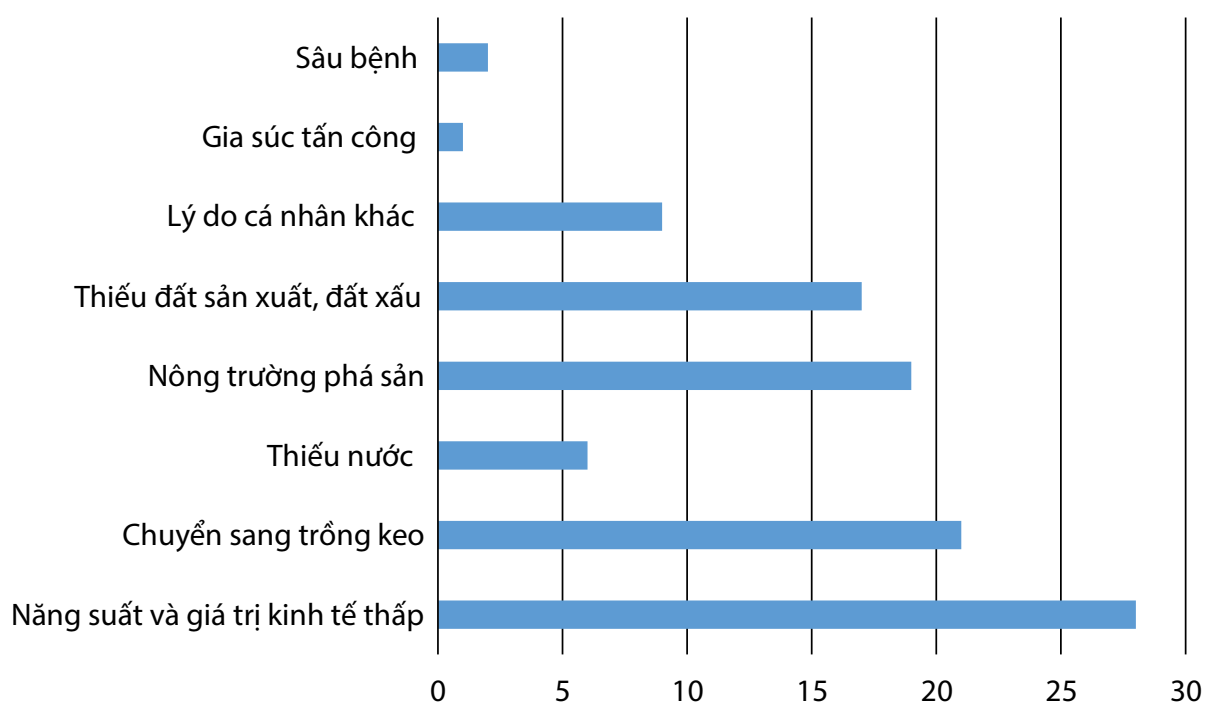

Hình 10. Lý do các hộ khảo sát chuyển đổi cây trồng (ĐVT: \%)

Nguồn: Tổng hợp từ kết quả khảo sát, 2020

PFES, tỷ lệ hộ có chăn nuôi cũng tăng lên từ $43.39 \%$ đến $66.29 \%$.

Về số lượng gia súc, tuy số lượng các loại vật nuôi còn ít, thể hiện quy mô nhỏ của hoạt động chăn nuôi ở đây nhưng sau PFES, phân lớn số lượng gia súc, gia cầm và vật nuôi của các thôn thuộc hai nhóm đều gia tăng. Như ở thôn có PFES, trước 2014, tổng cộng cả bốn thôn chỉ có 40 con dê, 42 con lợn thì sau PFES, số lượng dê và lợn đã tăng gần gấp 3 lần lên 117 con dê và 117 con lợn. Ngoại trừ bò, trâu và cá, số lượng các vật nuôi còn lại ở các thôn tham gia đều cao hơn thôn không tham gia PFES. Như sau PFES, thôn không tham gia PFES chỉ có 170 con vịt, 571 con gà thì ở thôn có PFES số lượng vịt gấp hơn 2 lân là 401 con vịt và số lượng gà gấp 1.7 lần là 998 con gà.

Tuy số lượng vật nuôi tăng lên sau khi PFES ra đời nhưng tổng thu nhập từ chăn nuôi không tăng, thậm chí tại các thôn không tham gia PFES, tổng thu từ chăn nuôi còn giảm. Nhìn vào cơ cấu thu nhập từ chăn nuôi, bò và trâu đều mang đến 


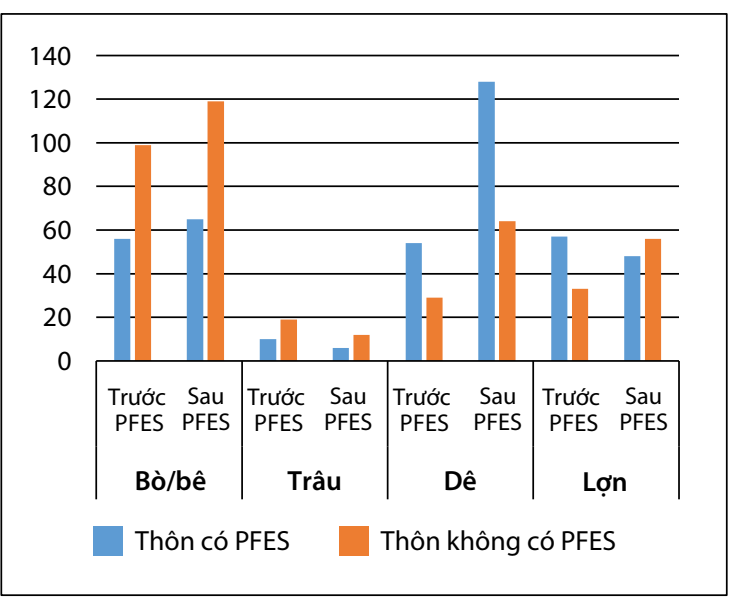

Hình 11. Số lượng vật nuôi tại các nông hộ

Nguồn: Tổng hợp từ kết quả khảo sát, 2020

những nguôn thu lớn nhất cho các hộ gia đình nhưng sau thời điểm PFES ra đời, có những biến động thị trường khiến cho giá các vật nuôi này giảm đi. Các loại gia cầm và vật nuôi khác tuy có số lượng lớn nhưng mang lại giá trị không cao cho các hộ và nhiều hộ cũng chỉ chăn nuôi vì mục đích sử dụng cho gia đình chứ không bán. Vì vậy tổng thu từ chăn nuôi của các hộ tương đối thấp, trung bình chỉ 6.73 triệu đồng/hộ ở thôn tham gia PFES và 7.35 triệu đồng/hộ ở thôn không tham gia PFES (sau năm 2014).

Về chi phí chăn nuôi, trong cả hai nhóm, đã có sự giảm đáng kể trong chi phí chăn nuôi sau thời điểm PFES ra đời so với trước kia. Cụ thể, đối với thôn tham gia PFES, chi phí chăn nuôi trung bình đã giảm từ 8.15 triệu đồng/hộ xuống còn 4.54 triệu đồng/hộ. Còn các thôn không tham gia cũng giảm từ 9.13 triệu đông/hộ xuống còn 7.96 triệu đông/hộ.

Các thôn không tham gia PFES phải bỏ ra chi phí cao hơn thôn tham gia PFES. Như thôn Ta Lo A Hố (không tham gia PFES) sau PFES trung bình một hộ phải đâu tư 9.52 triệu đông cho chăn nuôi thì thôn đối chứng, $\mathrm{A}$ Đeeng Par Lieng 1 (có tham gia PFES)

Trong cơ cấu chi phí thì tiền giống chiếm tỷ lệ cao nhất, chiếm 58\% trong chi phí các hộ tham gia $\mathrm{PFES}$ phải trả và chiếm $93 \%$ chi phí của hộ không tham gia PFES phải trả (sau thời điểm PFES ra đời). Sau thời điểm PFES, chi phí giống giảm xuống đối với cả hai nhóm dù số lượng gia súc tăng lên sau PFES. Điều này một phần là do

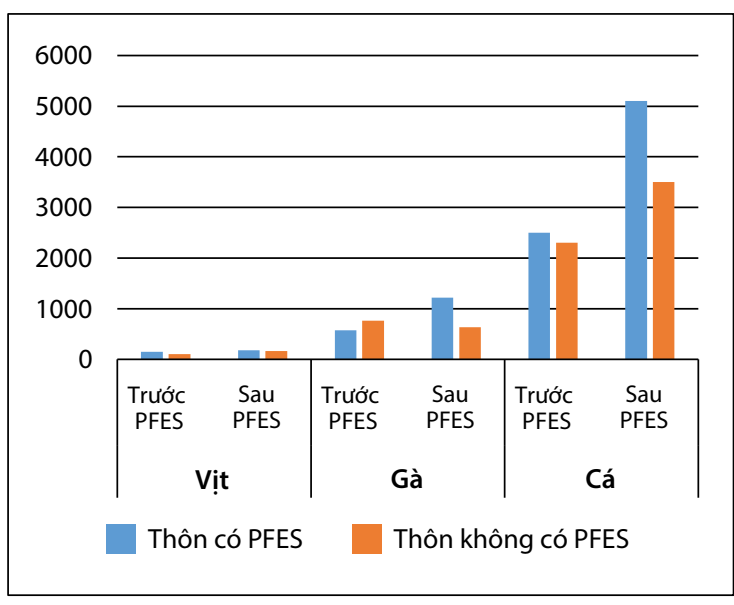

sự sinh sôi phát triển của đàn gia súc đã được đầu tư trước PFES, một phân là do một số hộ nhận được hỗ trợ từ chương trình cấp bò giống miễn phí của Nhà nước hay được người thân cho con giống và có thể do những biến động trong thị trường giống.

Thức ăn là khoản chi lớn thứ hai trong các chi phí cả hai nhóm phải trả. Vì có thể tận dụng được các bãi cỏ tự nhiên, rau củ và phụ phẩm từ nông nghiệp nên chi phí thức ăn không quá lớn đối với đa phân các hộ. Riêng đối với một hộ chăn nuôi ngựa tại thôn Đụt Lê Triêng 2 (tham gia PFES) do tăng quy mô trang trại dê từ 3 con lên 50 con nên chi phí thức ăn tăng đáng kể khiến chi phí thức ăn trung bình sau PFES của các thôn tham gia PFES tăng lên.

Mặc dù chi phí giảm nhửng do tổng thu từ chăn nuôi cũng giảm nên thu nhập thực sau khi trừ đi chi phí của các hộ chăn nuôi sau PFES đều thấp hơn trước PFES cho cả hai nhóm. Như thôn A Đeeng Par Lieng 1 có tham gia PFES, thu nhập từ chăn nuôi của các hộ chăn nuôi giảm từ 15.41 triệu trước PFES xuống còn 3.14 triệu đồng/hộ sau PFES. Đặc biệt là tại các thôn không tham gia PFES, thu nhập từ chăn nuôi rất thấp, thậm chí chi nhiều hơn thu như Ta Ay Ta và Ta Lo A Hố.

\subsubsection{Các khoản thu nhập khác}

Ngoài thu nhập từ trồng trọt, chăn nuôi, các hộ khảo sát còn có thu nhập từ những hoạt động khác, trong đó nhiều nhất là đến từ công việc làm thuê. Tại các thôn có PFES, 57.04\% hộ có đi 


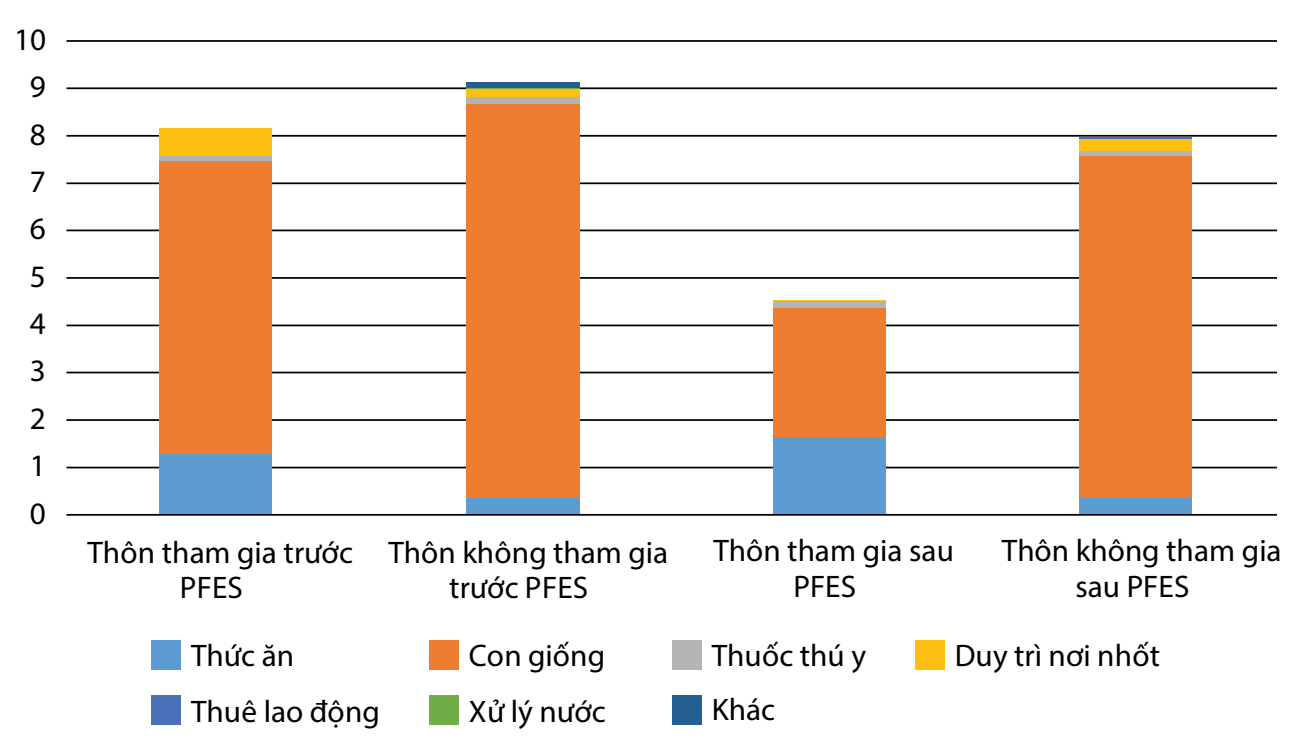

Hình 12. Cơ cấu chi phí chăn nuôi của nông hộ (ĐVT: triệu đồng)

Nguồn: Tổng hợp từ kết quả khảo sát, 2020

Bảng 17. Thu nhập từ chăn nuôi của hộ

\begin{tabular}{|c|c|c|c|c|c|c|c|}
\hline \multirow[t]{3}{*}{ Chỉ tiêu } & \multicolumn{3}{|c|}{ Thôn có PFES } & \multicolumn{3}{|c|}{ Thôn không có PFES } & \multirow{3}{*}{$\begin{array}{l}\text { Chênh lệch } \\
\text { (sau PFES) }\end{array}$} \\
\hline & \multicolumn{2}{|c|}{ Trung bình } & \multirow[t]{2}{*}{ So sánh } & \multicolumn{2}{|c|}{ Trung bình } & \multirow[t]{2}{*}{ So sánh } & \\
\hline & Trước PFES & Sau PFES & & Trước PFES & Sau PFES & & \\
\hline $\begin{array}{l}\text { Tỷ lệ hộ tham gia } \\
\text { chăn nuôi (\%) }\end{array}$ & 30.49 & 61.18 & 30.69 & 41.72 & 68.74 & 27.02 & -7.56 \\
\hline $\begin{array}{l}\text { Giá trị dàn vật } \\
\text { nuôi/hộ tham gia } \\
\text { (triệu đồng/hộ) }\end{array}$ & 19.51 & 16.74 & -2.77 & 28.69 & 23.87 & -4.82 & -7.13 \\
\hline $\begin{array}{l}\text { Doanh thu/hộ } \\
\text { tham gia (triệu } \\
\text { đồng) }\end{array}$ & 10.15 & 6.94 & -3.21 & 14.11 & 6.38 & -7.73 & 0.56 \\
\hline $\begin{array}{l}\text { Chi phí/hộ tham } \\
\text { gia (triệu đồng/ } \\
\text { hộ) }\end{array}$ & 9.86 & 5.72 & -4.14 & 13.52 & 6.95 & -6.57 & -1.23 \\
\hline $\begin{array}{l}\text { Thu nhập hỗn } \\
\text { hợp/hộ tham gia } \\
\text { (triệu đồng/hộ) }\end{array}$ & 0.29 & 1.22 & 0.93 & 0.59 & -0.57 & -1.16 & 1.79 \\
\hline
\end{tabular}

Nguồn: Tổng hợp từ kết quả khảo sát, 2020

làm thuê, thấp hơn thôn không có PFES nhưng tại cả hai nhóm, mức thu nhập từ công việc làm thuê đều trong khoảng 24 triệu đông/hộ có làm thuê. Chỉ có $16.48 \%$ hộ có lương ổn định tại thôn có PFES nhưng đây là nguồn thu nhập lớn nhất cho các hộ này, mang về trung bình 25.87 triệu đông/hộ. Mức lương trung bình của các hộ có công việc cố định ở thôn không có PFES cao hơn thôn có PFES, ở mức 28.2 triệu đông/hộ. Sau thu nhập từ làm thuê và tiền lương, các khoản hỗ trợ của Nhà nước từ các chương trình dự án cũng giúp các hộ có thêm từ 7 - 9 triệu đồng tuy nhiên chỉ có 6 - 7\% hộ được nhận khoản hỗ trợ này. Khoảng 5.81\% các hộ ở thôn PFES nhận được tiên gửi về của người thân trị giá trung bình 6.85 triệu đông/hộ. Tỷ lệ hộ được người nhà gửi tiền vể ở thôn không có PFES cao gần gấp 2 lần thôn có $P F E S$ và số tiền cũng lớn hơn ở mức $9.73 \%$. 

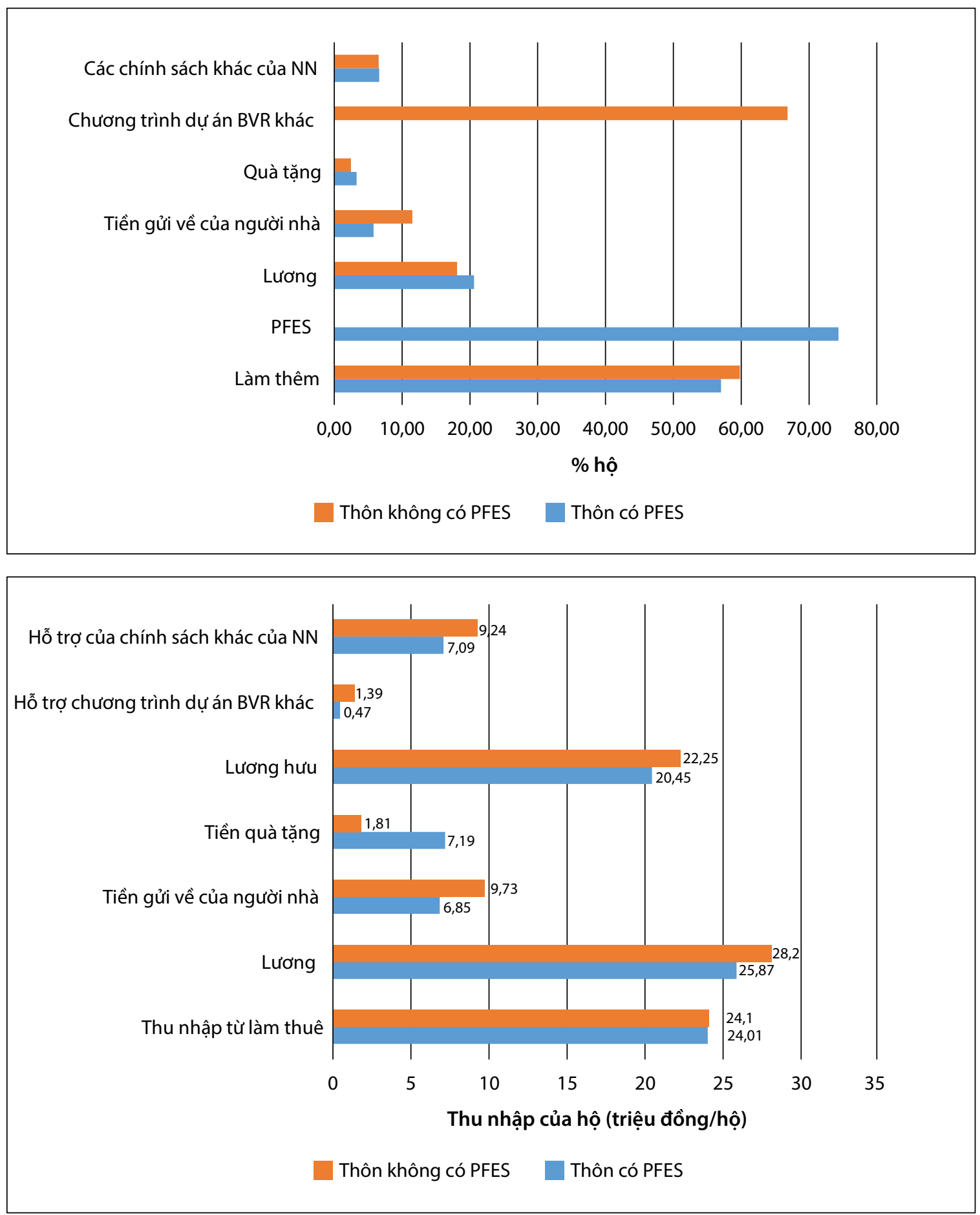

Hình 13. Tỷ lệ và thu nhập trung bình hộ từ các khoản thu nhập khác (\%)

Nguồn: Tổng hợp từ kết quả khảo sát, 2020

\section{2 Đóng góp nguồn thu và tác động của thu nhập từ PFES}

\subsubsection{Tác động kinh tế của PFES đối với cộng đồng}

Theo kế hoạch hàng năm thì các cộng đông đều phải xây dựng kế hoạch chi tiêu các khoản được nhận PFES hàng năm để các đơn vị liên quan giám sát việc triển khai nguồn chi khi có yêu cầu về kiếm tra giám sát. Cơ cấu nguồn chi được thông qua tại các cuộc họp cộng đồng qua kết quả phỏng vấn người $\mathrm{am}$ hiểu và thảo luận nhóm theo bảng chi tiết bên dưới, bảng 18 được thu thập bằng cách lấy mức trung bình cơ cấu kế hoạch chi tiêu của các cộng đông từ phỏng vấn 
Bảng 18. Cơ cấu kế hoạch chi tiêu trung bình hàng năm từ tiền PFES của các cộng đồng được khảo sát

\begin{tabular}{llc}
\hline STT & Mục chi & Tỷ lệ \% chi trả \\
\hline 1 & Ngày công tuần tra BVR & $60-70$ \\
\hline 2 & Mua sắm trang phục công cụ hỗ trợ & $8-10$ \\
\hline 3 & Sơ kết, tổng kết & $8-10$ \\
\hline 4 & Hỗ trợ ban quản lý rừng & $5-10$ \\
\hline 5 & Văn phòng phẩm & $1-2$ \\
\hline 6 & Chi khác & $3-4$
\end{tabular}

Nguồn: Tổng hợp từ kết quả khảo sát, 2020

Bảng 19. Kế hoạch chi tiêu năm 2019 của cộng đồng thôn 2 - Hồng Trung (cộng đồng A Đeeng Par Lieng 1)

\begin{tabular}{|c|c|c|c|c|c|}
\hline TT & Hạng mục & ĐVT & Số lượng & Đơn giá (đồng) & Thành tiền (đồng) \\
\hline 1 & Tuần tra bảo vệ rừng & Công & 180 & 150,000 & $27,000,000$ \\
\hline 2 & $\begin{array}{l}\text { Tuyên truyền phổ biến công tác } \\
\text { QLBVR }\end{array}$ & Cuộc & 3 & $1,000,000$ & $3,000,000$ \\
\hline 3 & Mua trang phục tuần tra bảo vệ rừng & Bộ & 15 & 300,000 & $4,500,00$ \\
\hline 4 & Rựa phát & Cái & 15 & 150,000 & $2,250,000$ \\
\hline 5 & \multicolumn{2}{|l|}{ Dự phòng khen thưởng, hỗ trợ rủi ro } & 3 & $1,000,000$ & $3,000,000$ \\
\hline 6 & Mua dép rọ & Đôi & 15 & 50,000 & 750,000 \\
\hline 7 & \multicolumn{2}{|l|}{ Chi cho ban quản lý } & 3 & 800,000 & $2,400,000$ \\
\hline 8 & \multicolumn{2}{|l|}{$\begin{array}{l}\text { Chi cho ban } \\
\text { kiểm soát }\end{array}$} & 2 & 500,000 & $1,000,000$ \\
\hline 9 & $\begin{array}{l}\text { Chi Sơ, tổng kết } \\
\text { quản lý BVR }\end{array}$ & Đợt & 2 & $3,500,000$ & $7,000,000$ \\
\hline 10 & Chi làm biển báo cấm & Cái & 5 & 300,000 & $1,500,000$ \\
\hline \multirow[t]{4}{*}{11} & \multicolumn{3}{|l|}{ Chi văn phòng phẩm } & & 0 \\
\hline & + Mua giấy A4 & Ram & 4 & 100,000 & 400,000 \\
\hline & + Mua bút & Hộp & 2 & 80,000 & 160,000 \\
\hline & + Phai đựng hồ sơ & Cái & 5 & 50,000 & 250,000 \\
\hline 12 & Chi khác & & & & 454,000 \\
\hline \multicolumn{5}{|c|}{ Tổng cộng } & $52,980,000$ \\
\hline
\end{tabular}

Ghi chú: các định mức này có thể thay đổi tùy thuộc vào cộng đồng Nguồn: Kế hoạch chi tiêu của cộng đồng A Đeeng Par Lieng 1, 2019

người am hiểu (trưởng thôn, trưởng ban quản lý rừng).

Tuy nhiên khi đi vào thực tế triển khai, cơ chế nguồn chi này lại có nhiều sự thay đổi và có nhiều mục chi phát sinh không nằm trong kế hoạch được phê duyệt.

Kết quả thảo luận nhóm và phỏng vấn người am hiểu là cán bộ thôn và thành viên ban quản lý rừng cộng đồng cho thấy mục chi cho ngày công tuân tra không thay đổi, vì định mức ngày công tương đối thấp nên khó có thể giảm hơn nữa, sẽ làm cho thành viên không hài lòng. Các mục chi phát sinh gồm có hỗ trợ hoạt động cộng đồng và hỗ trợ cán bộ địa phương lập thủ tục, hô sơ chi trả DVMTR.

Đối với mục chi hoạt động cộng đồng thì hâuu như các thành viên trong cộng đông 
Bảng 20. So sánh giữa kế hoạch chi tiêu đã phê duyệt và trên thực tế

\begin{tabular}{llcc}
\hline STT & Mục chi & $\begin{array}{c}\text { Tỷ lệ \% chi trả trên kế } \\
\text { hoạch được phê duyệt }\end{array}$ & $\begin{array}{c}\text { Tỷ lệ \% chi trả } \\
\text { trên thực tế }\end{array}$ \\
\hline 1 & Ngày công tuần tra BVR & $60-70$ & $60-70$ \\
\hline 2 & Mua sắm trang phục công cụ hỗ trợ & $8-10$ & 5 \\
\hline 3 & Sơ kết, tổng kết & $8-10$ & 5 \\
\hline 4 & Hỗ trợ ban quản lý rừng & $5-10$ & 5 \\
\hline 5 & Văn phòng phẩm & $1-2$ & 1 \\
\hline 6 & Hoạt động cộng đồng ( lễ hội, xây dựng cơ sở hạ tầng) & & 10 \\
\hline 7 & Hỗ trợ cán bộ địa phương lập thủ tục, hồ sơ chi trả DVMTR & & $4-10$ \\
\hline 8 & Chi khác & $3-4$ & Phần còn lại \\
\hline
\end{tabular}

Nguồn: Phỏng vấn sâu, thảo luận nhóm, 2020

ủng hộ. Trước đây khi chưa tiến hành PFES thì để tổ chức các hoạt động cộng đồng cũng như chỉnh trang thôn xóm thì đêu phải vận động sự đóng góp của thành viên, từ khi có hỗ trợ của PFES, thay vì đóng góp như trước bà con đều tự nguyện trích từ tiền của cộng đông cho các hoạt động, vừa tạo tính đoàn kết vừa đỡ một mối lo đóng góp.

Mục hỗ trợ cán bộ địa phương lập thủ tục, hồ sơ chi trả DVMTR, kết quả khảo sát cho thấy các cộng đông dân tộc thiểu số khó tiếp cận trong việc hoàn thiện hồ sơ, mặc dù trong những năm vừa qua, quỹ BVPTR đã tiến hành khá nhiều đợt tập huấn xây dựng hồ sơ chi trả, nhưng mà việc triển khai còn nhiều vướng mắc. Thế nên đã có sự thỏa thuận giữa cộng đồng, nhóm hộ được giao bảo vệ rừng và cán bộ quản lý địa phương (ở đây được nhắc đến là cán bộ địa chính nông nghiệp xã) trong việc hỗ trợ làm hồ sơ chi trả. Cán bộ địa chính nông nghiệp sẽ tiến hành hoàn thiện hồ sơ chi trả, thành viên ban quản lý chỉ có trách nhiệm ký tên xác nhận.

Khi được trao đổi về lý do không tự hoàn thiện hồ sơ, nhiều ý kiến các thành viên chủ chốt của ban quản lý rừng cho rằng:

- Do trình độ dân trí thấp, hạn chế về phương tiện thông tin như máy vi tính cũng như không tự chủ động tiếp cận số liệu, thông tin về chi trả DVMTR để hoàn thiện hồ sơ.

- Một số cán bộ hạn chế trong chia sẻ thông tin, thiếu hướng dẫn sâu sát đến cộng đông và tự đề nghị trực tiếp để hỗ trợ làm hồ sơ.

Phỏng vấn sâu một số thành viên cốt cán thôn và ban quản lý rừng cộng đồng đối với mức chi này thì cho rằng không phù hợp và mong muốn được hỗ trợ hơn nữa từ quỹ BVPTR, đặc biệt là đơn giản hóa hồ sơ chi trả để cộng đồng có thể chủ động triển khai từ đó có thêm nguồn kinh phí hồ trợ cho các thành viên đi tham gia tuần tra bảo vệ rừng

Theo kế hoạch chi trả được phê duyệt qua các năm, việc chi trả tiên DVMTR được thực hiện 02 lần trong năm (01 lần tạm ứng và 01 lần thanh toán), dựa trên thủ tục, hồ sơ tạm ứng/thanh toán của chủ rừng. Tuy nhiên, qua phỏng vấn các trưởng thôn và các thành viên ban quản lý bảo vệ rừng các thôn được chi trả PFES, phương thức chi trả tiền PFES chủ yếu là trả vào cuối năm do người dân muốn nhận tiên một lần để phục vụ cho các hoạt động. Các thành viên trong ban quản lý rừng cộng đông đi cùng sẽ trực tiếp chấm công cho các hộ đi tuần tra, bảo vệ. Công đi tuần tra này sau đó sẽ nhân với định mức chi trả cho 1 ngày đi tuần tra bảo vệ rừng, thông thường là 100-150 nghìn đồng/ ngày/ người (mức chi trả phụ thuộc vào các cộng đông).

Các hoạt động chi trả sẽ diễn ra vào cuối năm theo phương thức Ban quản lý rừng cộng đông nhận tiền chi trả từ ngân hàng (được chuyển từ quỹ BVPTR) sau đó sẽ tiến hành họp để chi trả tiền công. Thời gian nhận của các hộ hâu như rơi vào tháng 1 (trùng vào thời điểm tết âm lịch). Sau khi nhận tiền chi trả thì hâu hết các hộ đều sử dụng cho mua sắm Tết hoặc chi phí khác, mức trung bình một hộ nhận được rơi vào tầm 1 triệu đến 2 triệu/hộ - nội dung này sẽ được giải thích chi tiết hơn ở phần thu nhập nông hộ. 
Bảng 21. Tổng số tiền PFES chi trả cho các địa điểm khảo sát năm 2019

Đơn vị: Đồng

\begin{tabular}{lrcc}
\hline Thôn & Hộ gia đình & Cộng đồng & Nhóm hộ gia đình \\
\hline A Đeeng Par Lieng 1 & 0 & $78,564,000$ & 0 \\
\hline A Đeeng Par Lieng 2 & 366,000 & $83,418,000$ & 0 \\
\hline Đụt Lê Triêng 2 & $1,860,000$ & $85,452,000$ & $30,510,000$ \\
\hline A Hướ Pa E & 576,000 & $29,880,000$ & 0 \\
\hline
\end{tabular}

Nguồn: Quỹ Bảo vệ và Phát triển rừng rừng tỉnh Thừa Thiên Huế (2019)

\subsubsection{Tác động kinh tế của PFES đối với hộ gia đình}

Trên địa bàn các thôn được khảo sát, rừng chủ yếu được giao cho cộng đông quản lý và bảo vệ. Còn những hình thức như giao cho hộ gia đình chỉ chiếm một phần nhỏ. Đối với thôn $\mathrm{A}$ Đeeng Par Lieng 1 không có việc giao rừng quản lý và bảo vệ cho hộ gia đình ở năm 2019. Hâu như đối với các thôn có thực hiện chương trình PFES thì nhóm hộ gia đình chỉ có ở thôn Đụt Lê Triêng 2 với số tiền được nhận là 30,510,000 đồng năm 2019. Còn lại ở 3 thôn có PFES: Thôn A Đeeng Par Lieng 1, A Đeeng Par Lieng 2, A Hươr $\mathrm{Pa} \mathrm{E}$ không có rừng được giao cho hộ gia đình. Việc giao rừng cho cộng đồng quản lý nhận được số tiền nhiều nhất ở 2 thôn: A Đeeng Par Lieng 2, Đụt Lê Triêng 2 với số tiền tương ứng là $85,452,000$ đông và 83,418,000 đông năm 2019. Thôn $\mathrm{A}$ Hươr Pa E nhận được số tiền giao cho cộng đông ít nhất trong các thôn khảo sát chỉ 29,880,000 đông năm 2019 (Bảng 21)

Trong các hộ được khảo sát, có 88 hộ (chiếm $72.72 \%$ ) được nhận tiền từ chi trả dịch vụ môi trường rừng. Trong đó thôn $\mathrm{A} H$ Hươr $\mathrm{Pa} \mathrm{E}$ có tỷ lệ hộ được nhận tiền PFES lớn nhất, sau đó đến các thôn Đụt - Lê Triêng 2 (74.19\%), A Đeeng Parlieng 1 (70\%) và $\mathrm{A}$ Đeeng Par Lieng 2 (60\%).

Số tiền các hộ nhận được cũng có sự chênh lệch giữa các thôn. Theo đó, các hộ ở thôn Đụt Lê Triêng 2 được nhận nhiều nhất trung bình là 3.75 triệu đông/hộ. Còn $\mathrm{A}$ Hươr $\mathrm{Pa} \mathrm{E}$ được nhận ít nhất tuy thời gian các hộ ở đây dành cho bảo vệ rừng lớn nhất. Điều này có thể giải thích một phần là do diện tích rừng ở $\mathrm{A} H$ Hươ $\mathrm{Pa} \mathrm{E}$ là nhỏ nhất trong cả bốn thôn nên số tiền nhận được từ Quỹ bảo vệ môi trường rừng thấp hơn các thôn khác trong khi số lượng hộ tham gia lại nhiêu hơn các thôn khác.

\subsection{Sử dung tiền chi trả PFES và các vấn để liển quan}

Trong 4 thôn có PFES được khảo sát (123 hộ), chỉ có một nửa số hộ được nhận tiền PFES biết về việc tiền $\mathrm{PFES}$ được quản lý như thế nào $(55 \%)$ và $64 \%$ được tham gia vào việc quyết định sử dụng tiên PFES. Ở một số thôn như A Hươr Pa $\mathrm{E}$, chỉ có $35 \%$ hộ biết cho thấy việc quản lý cân minh bạch hơn nữa và người dân cần được cung cấp thông tin đây đủ hơn.

Dù được nhận tiền từ PFES nhưng không phải hộ nào cũng biết ai là người chi trả PFES cho họ và khi nào thì họ được nhận tiền. Khi được hỏi vê đối tượng chi trả tiền PFES, có 77\% hộ nói họ biết người chi trả. Nhưng khi hỏi cụ thể đó là ai chi trả thì đa phân các hộ chỉ biết trưởng thôn, thủ quỹ thôn là những người trực tiếp đưa tiền cho họ. Có $4 \%$ hộ nói tới thủy điện, $16 \%$ nhắc tới Quỹ Bảo vệ rừng và Phát triển rừng, $6 \%$ nói kiểm lâm và có $1 \%$ nói là Nhà nước chi tiền.

Về thời hạn chi trả, trung bình 82\% hộ khẳng định họ biết thời hạn chi trả. Nhưng khi xem tỷ lệ của từng thôn thì số lượng người biết về thời hạn họ được nhận PFES khá thấp như thôn $\mathrm{A}$ Hươr Pa E chỉ có $54 \%$ số hộ nhận tiền PFES biết là khi nào họ được nhận tiền. Trung bình $88 \%$ hộ đánh giá là việc chi trả được thực hiện đúng hạn. $11 \%$ thì không rõ có đúng hạn hay không, đặc biệt tại thôn $\mathrm{A}$ Hươr PaE, nhiều người không biết hạn thanh toán nên không rõ mình nhận tiền có đúng cam kết ban đầu không. Riêng tại thôn Đụt Lê Triêng 2, 4\% hộ thông báo việc thanh toán cho họ bị muộn hai tháng nhưng họ không rõ lý do vì sao bị nhận tiền muộn.

Nếu có thắc mắc về việc quản lý và chi trả PFES, các hộ khảo sát nghĩ họ sẽ liên hệ với một số đâu mối như trưởng thôn, UBND xã, Quỹ Bảo vệ 


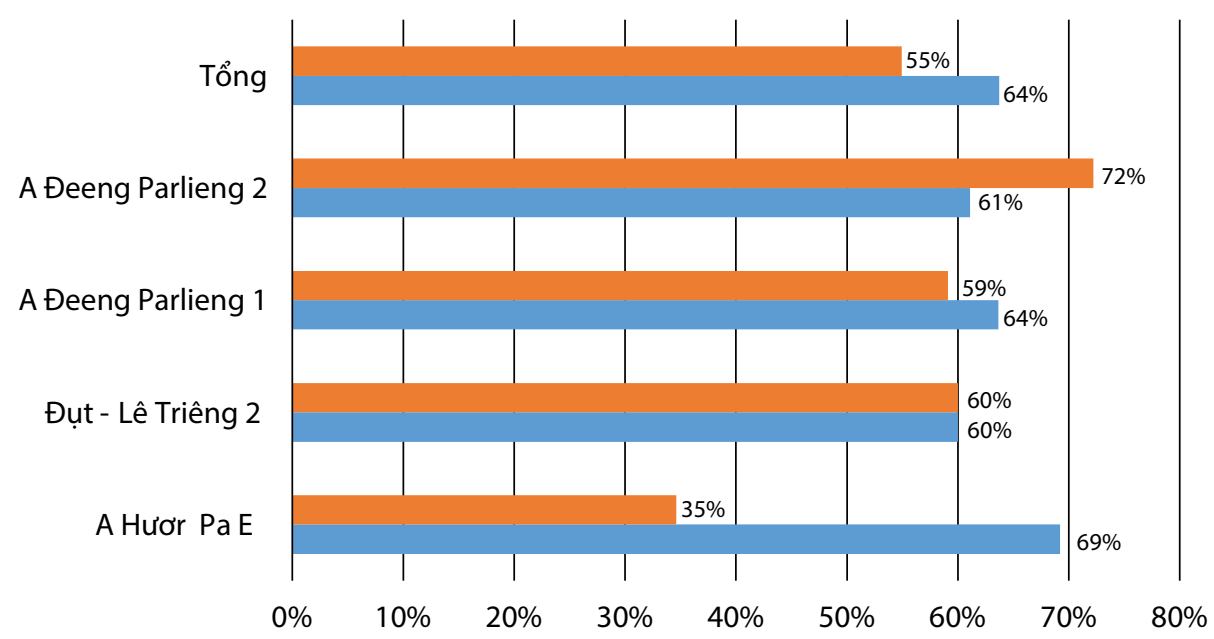

Tỷ lệ biết cách quản lý tiền PFES

Tỷ lệ tham gia quyết định sử dụng tiền PFES

Hình 14. Tỷ lệ hộ tham gia quyết định sử dụng và biết về quản lý tiền PFES

Nguồn: Tổng hợp từ kết quả khảo sát, 2020

Biết đối tượng chi trả $\quad$ Biết thời hạn chi trả

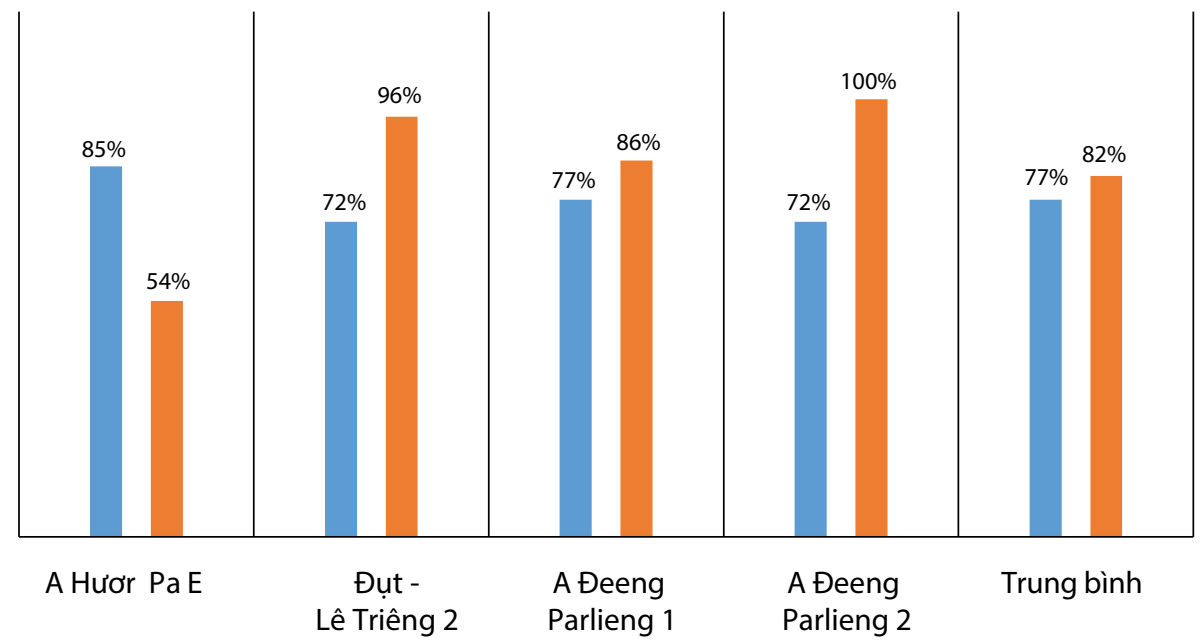

Hình 15. Tỷ lệ hộ biết đối tượng và thời hạn chi trả PFES

Nguồn: Tổng hợp từ kết quả khảo sát, 2020

rừng. Trong đó, trưởng thôn được nhiều người nhắc tới nhất (71\%), rồi tới UBND xã (11\%), điều này thể hiện vai trò quan trọng của trưởng thôn trong việc tuyên truyền phổ biến thông tin về PFES, tiến hành chi trả cũng như là cầu nối giữa Quỹ Bảo vệ rừng với các hộ bảo vệ rừng.

Khi nghiên cứu cơ cấu thu nhập của các hộ nhận được tiền từ PFES, có thể thấy với số tiền nhận được trung bình là 1.64 triệu đồng/hộ, PFES là nguôn thu lớn thứ năm trong các khoản thu nhập của hộ, sau tiền từ làm thuê, tiên lương, hoạt động nông nghiệp và chăn nuôi.

Tùy thuộc vào số tiền PFES mỗi hộ nhận được mà tỷ lệ đóng góp của $\mathrm{PFES}$ vào thu nhập hộ khác nhau. Như tại thôn Đụt Lê Triêng 2, trung bình các hộ nhận được 2.64 triệu đồng/ hộ nên PFES đóng góp 4.06\% vào thu nhập hộ. Tại A Đeeng Parlieng 2, các hộ chỉ nhận được 


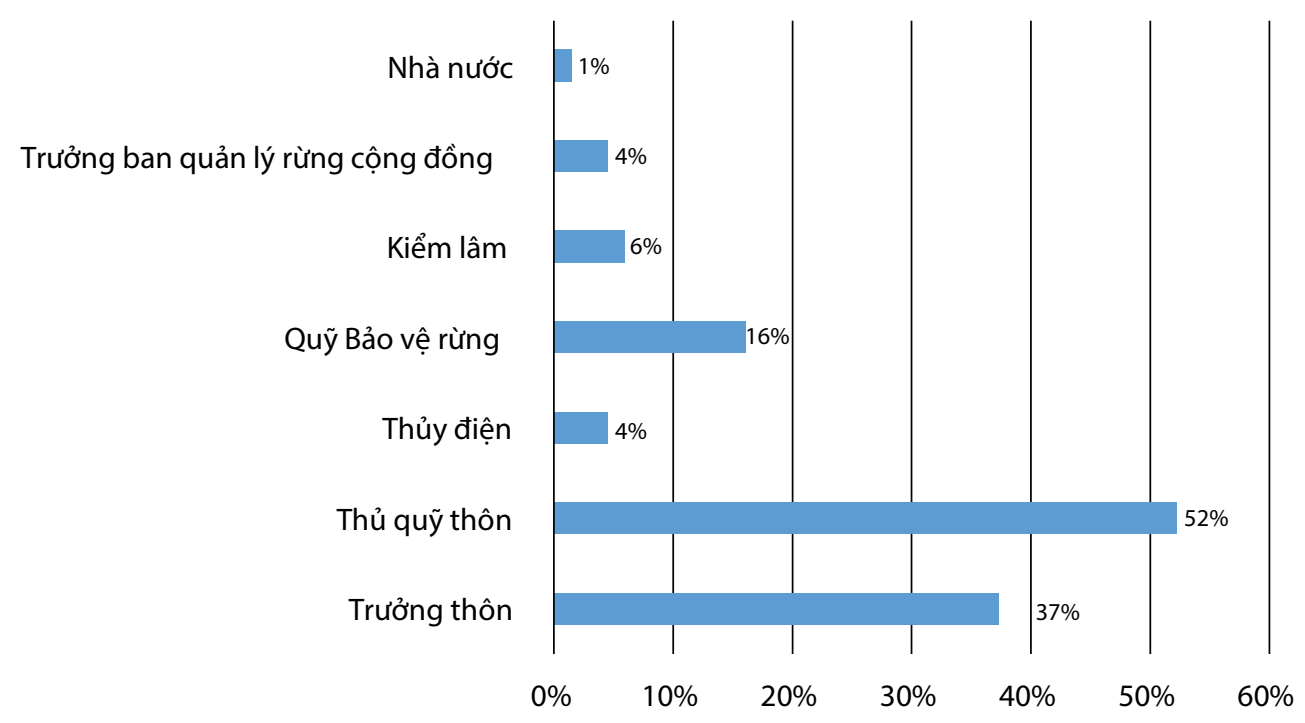

Hình 16. Đối tượng chi trả PFES theo quan điểm của các hộ

Nguồn: Tổng hợp từ kết quả khảo sát, 2020

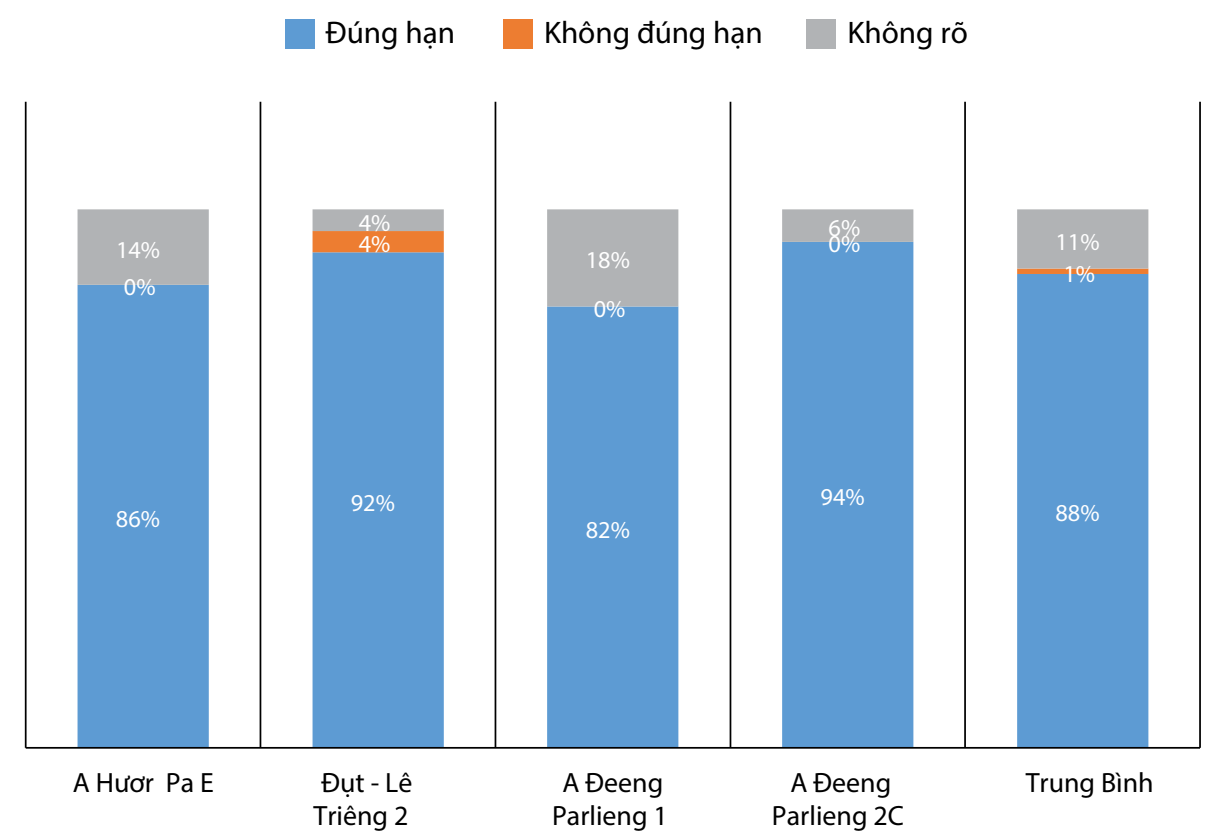

Hình 17. Ý kiến của hộ về thời hạn thanh toán và việc chi trả đúng hạn

Nguồn: Tổng hợp từ kết quả khảo sát, 2020

1.33 triệu đông/hộ trong khi tổng thu nhập của hộ ở đây lại cao nhất nên tỷ lệ đóng góp của PFES vào thu nhập hộ ở mức $1.81 \%$. Tính trung bình, PFES đóng góp $2.67 \%$ vào thu nhập của hộ.

Sau khi nhận được tiền PFES, các hộ đã sử dụng số tiền này để chi tiêu cho nhiều mục đích, trong đó có cả nhu câu của cá nhân, gia đình và cả các hoạt động thôn bản. 80\% hộ nói đến việc mua nhu yếu phẩm cho gia đình như gia vị, gạo, thực phẩm. Đặc biệt thời điểm chi trả là gần Tết Nguyên Đán nên số tiền nhận được PFES rất có ý nghĩa đối với người dân để họ có thể mua sắm Tết đây đủ. Đây là bước 2 trong thang PAPOLD giảm nghèo của hộ. $11 \%$ hộ dùng tiền để trả nợ, bao gồm cả trả nợ ngân hàng. Nhưng chỉ có 


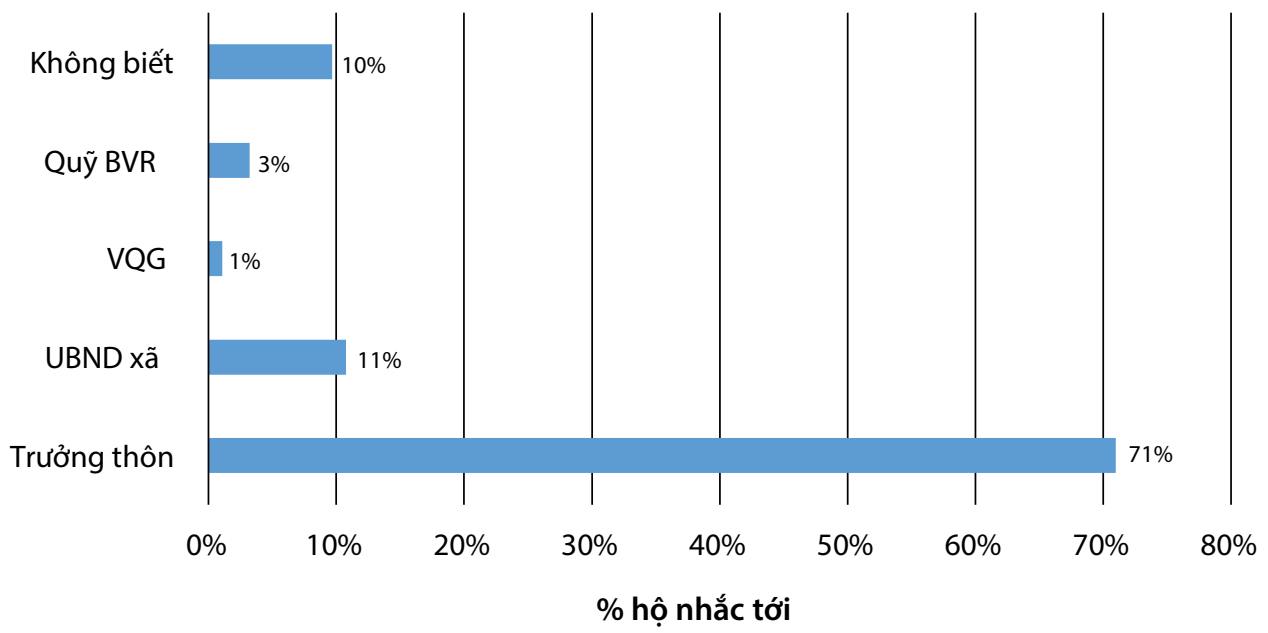

Hình 18. Những người hộ liên hệ khi có thắc mắc về PFES

Nguồn: Tổng hợp từ kết quả khảo sát, 2020
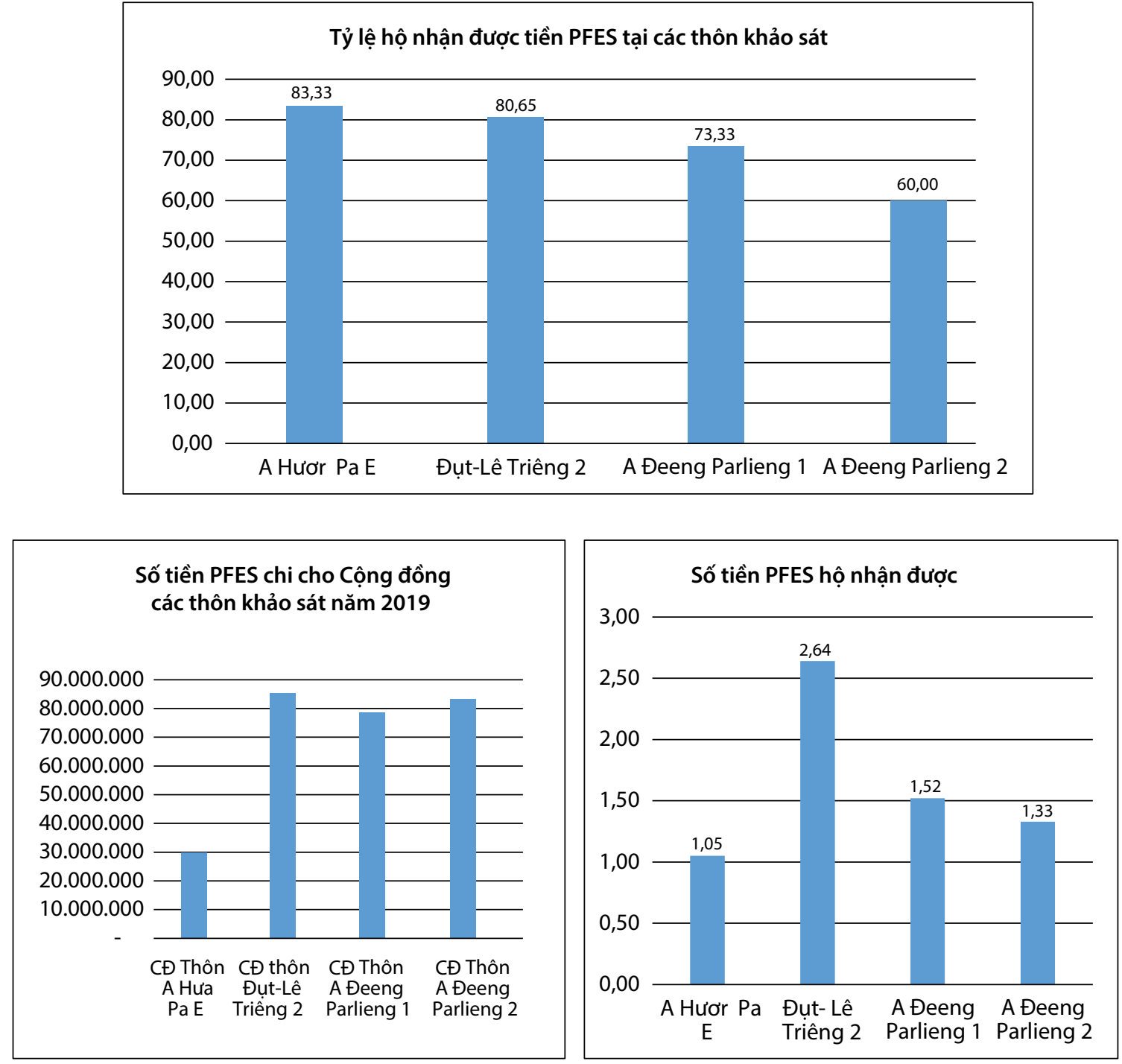

Hình 19. Số tiền PFES cộng đồng các thôn nhận được năm 2019

Nguồn: Quỹ Bảo vệ và Phát Triển Rừng tỉnh Thừa Thiên Huế, 2020
Hình 20. Số tiền PFES các hộ nhận được năm 2019

Nguồn: Tổng hợp kết quả khảo sát, 2020 


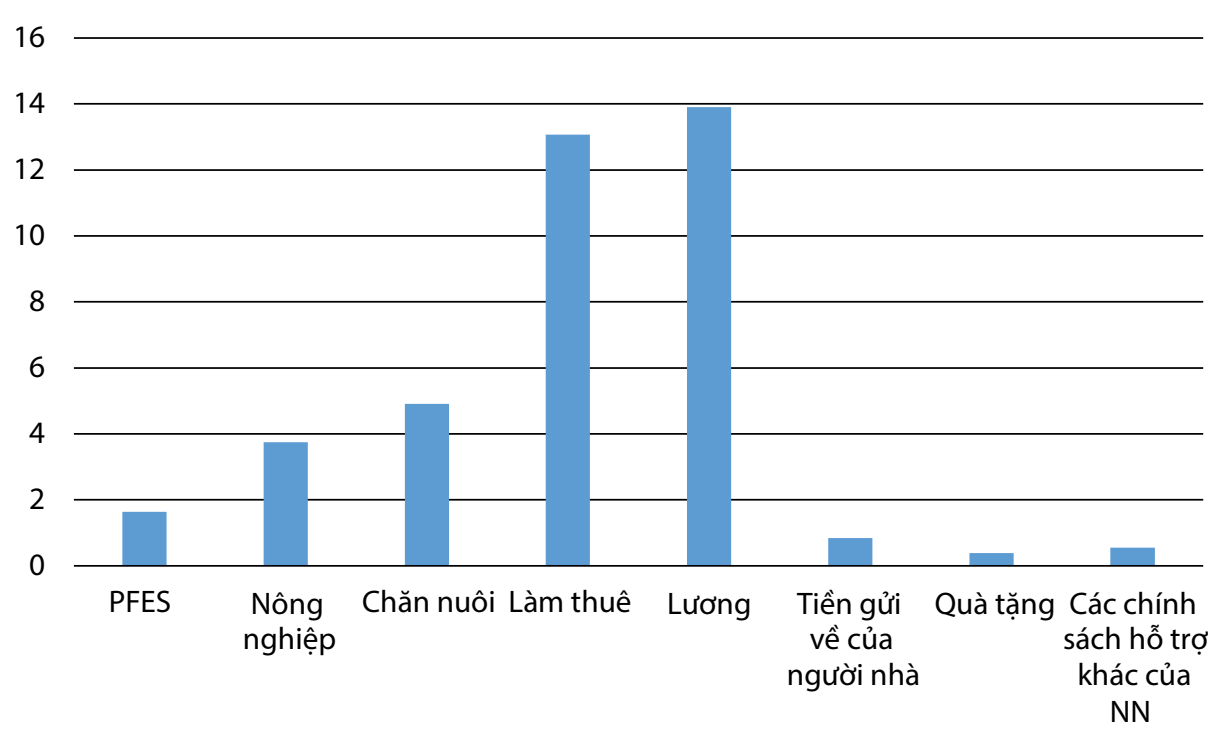

Hình 21. Các nguồn thu nhập của hộ được nhận tiền từ PFES

Nguồn: Tổng hợp từ kết quả khảo sát, 2020

Bảng 22. Tổng hợp các loại thu nhập của các hộ tham gia PFES (triệu đồng/hộ)

\begin{tabular}{lrrrrr}
\hline Chỉ tiêu & \multicolumn{5}{c}{ Thôn có PFES } \\
\cline { 2 - 6 } & $\begin{array}{c}\text { A Hươr } \\
\text { Pa E }\end{array}$ & $\begin{array}{c}\text { Đụt - Lê } \\
\text { Triêng 2 }\end{array}$ & $\begin{array}{c}\text { A Đeeng } \\
\text { Parlieng } 1\end{array}$ & $\begin{array}{c}\text { A Đeeng } \\
\text { Parlieng 2 }\end{array}$ & $\begin{array}{c}\text { Trung } \\
\text { bình }\end{array}$ \\
\hline Số hộ nhận tiền PFES & 25.00 & 25.00 & 22.00 & 18.00 & 22.50 \\
\hline Số tiền PFES được nhận & 1.05 & 2.64 & 1.52 & 1.33 & 1.64 \\
\hline Thu nhập từ Nông nghiệp của hộ nhận tiền & 7.07 & 1.72 & 2.99 & 3.20 & 3.75 \\
PFES & & & & & \\
\hline Thu nhập từ chăn nuôi của hộ nhận tiền PFES & 1.56 & 7.32 & 4.94 & 5.83 & 4.91 \\
\hline Tổng thu từ rừng & 0.00 & 0.00 & 0.00 & 0.03 & 0.01 \\
\hline Thu nhập từ làm thuê của hộ nhận tiền PFES & 8.51 & 12.46 & 20.73 & 10.56 & 13.07 \\
\hline Lương của hộ nhận tiền PFES & 8.09 & 15.86 & 0.00 & 31.66 & 13.90 \\
\hline Cho thuê đất, tài sản, cho vay tiền & 0.00 & 0.00 & 0.00 & 0.00 & 0.00 \\
\hline Tiền gửi về của người nhà & 3.36 & 0.00 & 0.00 & 0.00 & 0.84 \\
\hline Quà tặng & 0.72 & 0.00 & 0.00 & 0.83 & 0.39 \\
\hline Thừa kế & 0.00 & 0.00 & 0.00 & 0.00 & 0.00 \\
\hline Lương hưu & 0.00 & 0.00 & 0.00 & 0.00 & 0.00 \\
\hline Chương trình dự án BVR khác & 0.00 & 0.00 & 0.00 & 0.00 & 0.00 \\
\hline Các chính sách hỗ trợ khác của NN & 0.00 & 0.00 & 0.00 & 2.18 & 0.55 \\
\hline Tổng thu nhập của hộ nhận tiền PFES & 55.36 & 65.00 & 52.18 & 73.62 & 61.54 \\
\hline Đóng góp của PFES vào thu nhập của hộ (\%) & 1.90 & 4.06 & 2.91 & 1.81 & 2.67 \\
\hline & & & & & \\
\hline
\end{tabular}

$2 \%$ dùng tiền để mua con giống, $4 \%$ mua phân bón và $9 \%$ dùng tiên để đóng học cho con cái là những bước cao trong bậc thang thoát nghèo PAPOLD. Như đã phân tích về phần an sinh, tiêu dùng, $\mathrm{y}$ tế, giáo dục, trả nợ đều là những nhu câu rất cấp thiết mà các hộ cảm thấy thu nhập hiện tại của họ không thể đủ trang trải. Với khoản thu nhập thêm từ tiền PFES, những nhu cầu chưa được giải quyết này đã phần nào được đáp ứng.

Về các hoạt động công cộng, tiền PFES cũng được sử dụng vào nhiều hoạt động có ý nghĩa để cải thiện điều kiện cơ sở vật chất thôn bản và đặc biệt hỗ trợ hoạt động bảo vệ rừng. 21\% hộ nhắc 


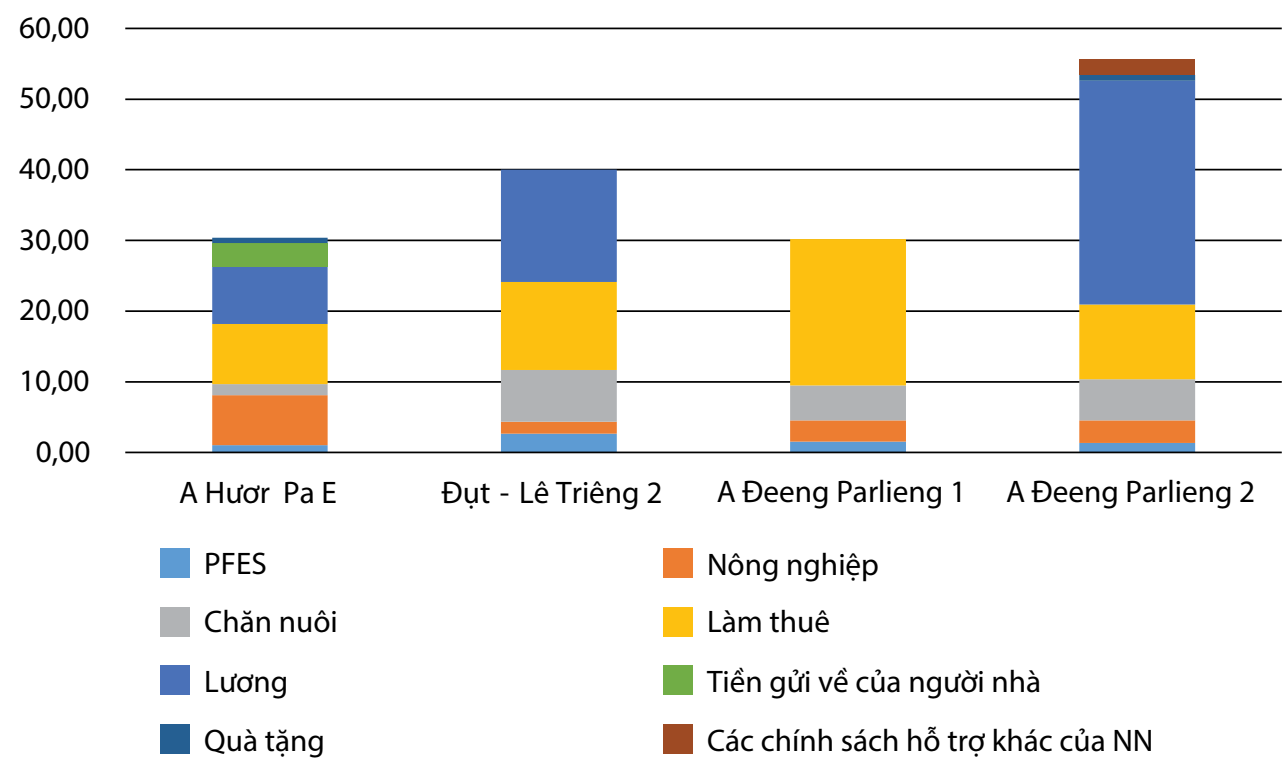

Hình 22. Cơ cấu thu nhập của các hộ nhận được tiền PFES

Nguồn: Tổng hợp từ kết quả khảo sát, 2020

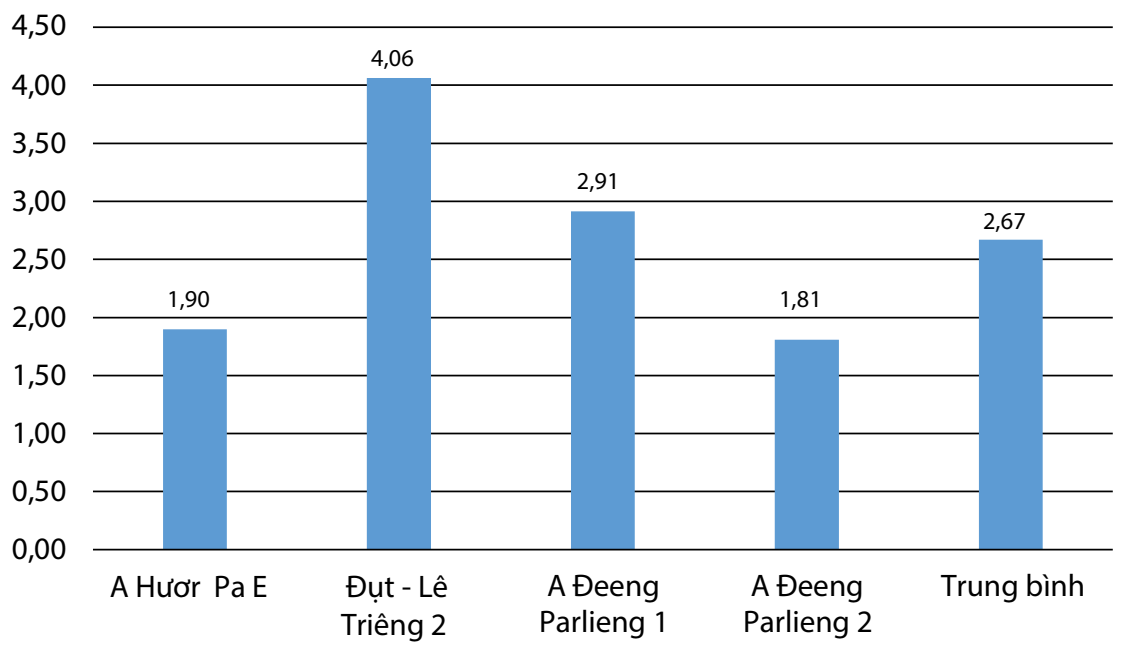

Hình 23. Tỷ lệ đóng góp của tiền PFES vào thu nhập của hộ

Nguồn: Tổng hợp từ kết quả khảo sát, 2020

tới việc dùng tiền PFES để đóng góp cho thôn sửa điện, mua bàn ghế, cải tạo nhà văn hóa, xây dựng cổng chào thôn, đóng góp vào quỹ ma chay, cưới hỏi, tổ chức họp tổng kết và thậm chí trích cho Hội Phụ nữ, Hội Nông dân để họ có thêm kinh phí hoạt động. Số tiên này cũng được dùng để trang trải chi phí nhân công, mua dụng cụ bảo hộ và nước uống cho người đi tuần tra bảo vệ rừng. Có thể thấy tiền PFES đã được sử dụng đúng mục đích cải thiện đời sống của người giữ rừng và tái đâu tư một phân vào công tác bảo vệ rừng.
Các hộ cũng đưa ra những đánh giá cụ thể về tác động của PFES. Ba tác động được đề cập đến nhiêuu nhất là PFES giúp nâng cao hiểu biết và ý thức của người dân về bảo vệ rừng (79\% hộ đề cập), rừng tốt lên (77\% hộ đề cập) và cải thiện đời sống như việc làm, đường sá, công trình công cộng ( $50 \%$ hộ đề cập). 33\% cho rằng thu nhập của họ tốt lên trong khi $9 \%$ nói đời sống vẫn như cũ và $7 \%$ cho rằng thu nhập của họ kém đi, chủ yếu vì hộ không còn được khai thác gỗ nữa. Về tác động xấu, 24 hộ (chiếm 13\% những người trả 


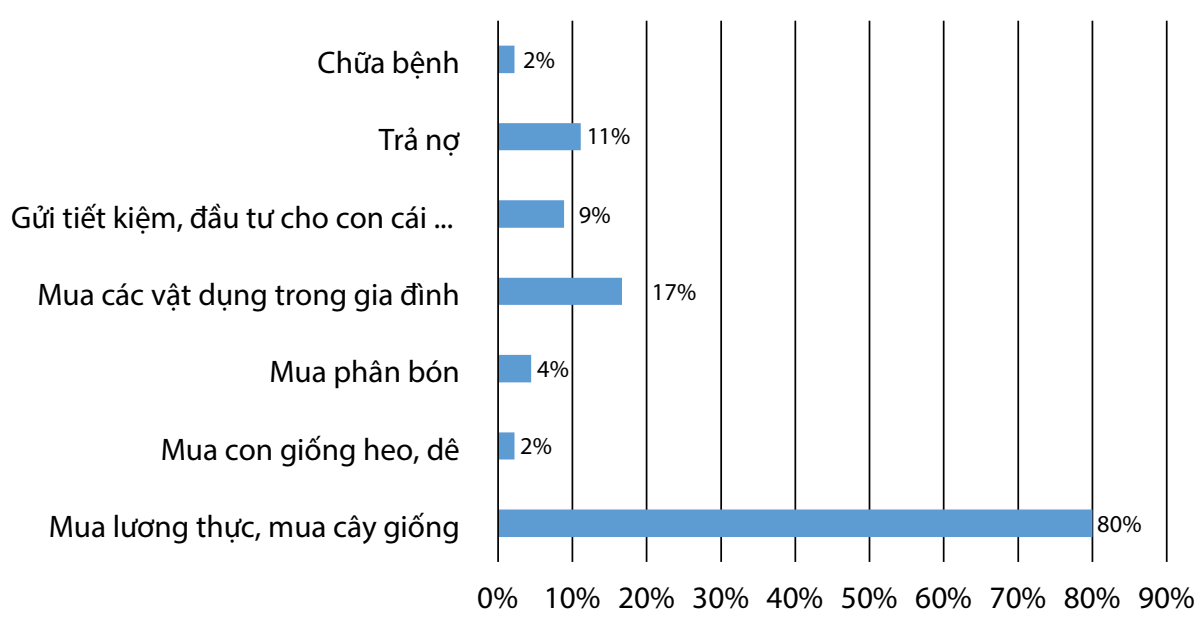

Hình 24. Mục đích sử dụng tiền PFES của hộ

Nguồn: Tổng hợp từ kết quả khảo sát, 2020

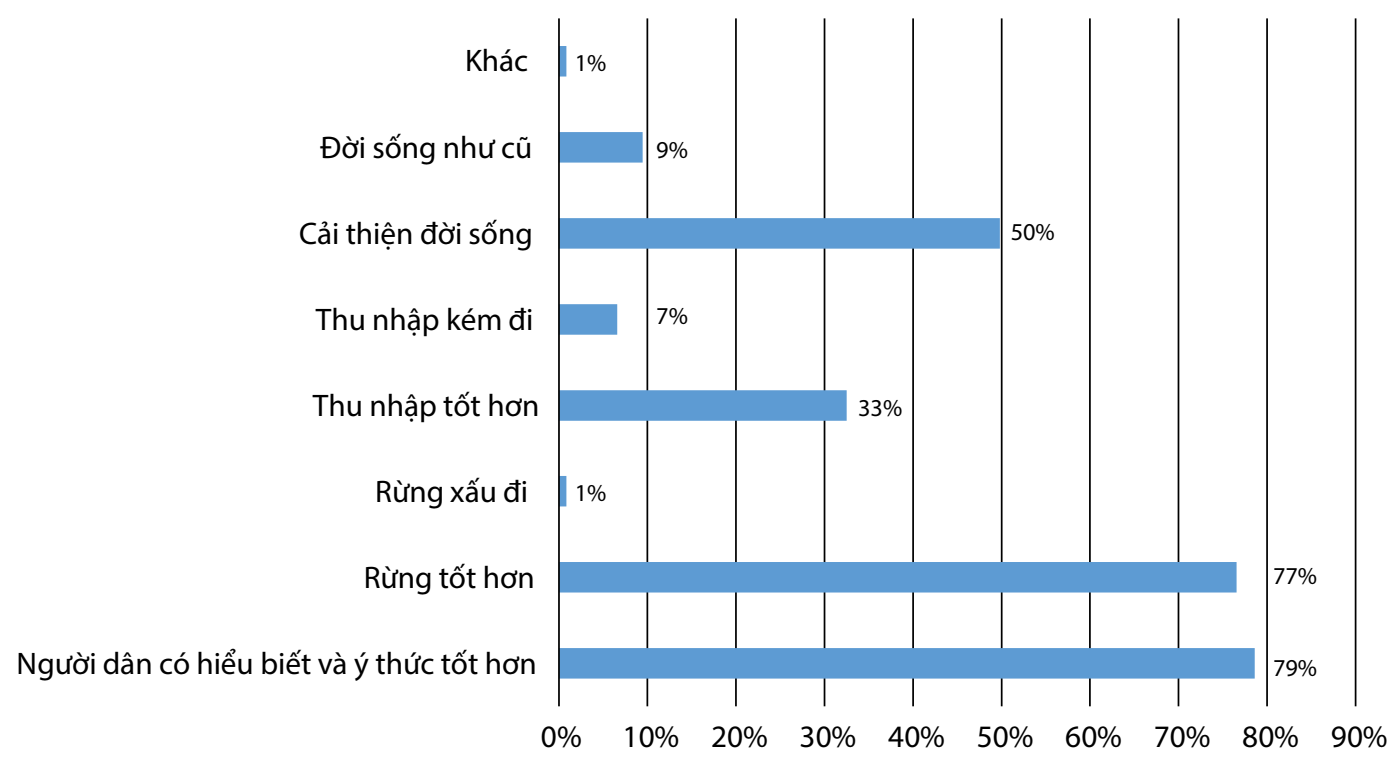

Hình 25. Đánh giá của hộ về tác động của PFES

Nguồn: Tổng hợp từ kết quả khảo sát, 2020

lời) cho rằng tác động không tốt của PFES đối với gia đình họ là họ không được phát rẫy, không được khai thác gỗ và lâm sản nữa và phải làm nhiều thủ tục nếu muốn lấy gỗ về làm nhà. Một hộ cho rằng việc sử dụng tiền PFES để tổ chức liên hoan cả làng bao gồm những người không đi bảo vệ rừng là không công bằng.

Kết quả phỏng vấn người am hiểu (cán bộ, trưởng thôn, thành viên ban quản lý bảo vệ rừng thôn) cho thấy chính sách PFES đạt được nhiêu kết quả tích cực. PFES đã thúc đẩy nâng cao nhận thức cho bà con cũng như tạo tính gắn kết giữa các thành viên trong cộng đồng, cải thiện thêm một phân thu nhập cho bà con, đặc biệt là các hộ nghèo. Tiên PFES được chi trả cho các thành viên cộng đồng vào cuối năm, điều này tạo thuận lợi cho các hộ sử dụng tiền mua sắm cho gia đình vào dịp Tết. Đông thời khi thực hiện chính sách người dân đã xem mình như chủ rừng và phải có trách nhiệm bảo vệ và phát triển rừng, hâu như chấm dứt hẳn việc các thành viên trong cộng đông chặt phá rừng, việc thu hoạch lâm sản phi gỗ được giám sát tốt hơn và hơn thế nữa từ khi có PFES các hoạt động cộng đông có thêm nguôn thu để tổ chức như các lễ hội mừng lúa mới, lễ tế làng... Bên cạnh các yếu tố tích cực thì tình trạng phá rừng do lâm tặc đến từ các địa phương khác vẫn còn, việc chi trả vẫn còn gặp nhiều khó khăn đặc biệt trong tiến hành làm hồ sơ thủ tục, quản lý kinh phí.. cũng đang là những rào cản trong việc thực hiện chính sách. 


\section{Kết luận}

Với mục tiêu kép vừa bảo vệ và phát triển rừng vừa đóng góp vào xóa đói giảm nghèo, chính quyền địa phương luôn ưu tiên hỗ trợ người nghèo tham gia vào PFES. Tuy nhiên, việc PFES chỉ đóng góp $2.67 \%$ vào thu nhập của hộ gia đình và chỉ đứng thứ 5 về tầm quan trọng trong tổng thu nhập của hộ gia đình cho thấy PFES khó có thể giúp được các hộ gia đình thoát nghèo, mà chỉ một phân đóng góp vào trang trải cuộc sống hàng ngày. Điều này cũng có nghĩa động lực kinh tế để tham gia PFES đối với người dân cũng rất hạn chế. Để nâng cao hiệu quả kinh tế của PFES, tiền PFES cần được chi trả đúng hạn hỗ trợ người dân kịp thời trong việc trang trải đời sống.

Như báo cáo đã trình bày, tiếp cận tài sản tự nhiên và đất đai đóng góp một phần quan trọng trong việc đảm bảo sinh kế của người dân địa phương. Các hộ gia đình có diện tích rừng nhiêu hơn sẽ có thu nhập cao hơn từ PFES. Ngoài ra, nhờ có PFES, nhiều hộ gia đình đã được cấp giấy chứng nhận quyền sử dụng đất do vậy cũng có điêu kiện pháp lí ổn định hơn để tham gia và hưởng lợi từ các chương trình bảo vệ phát triển rừng nói chung và $\mathrm{PFES}$ nói riêng. Đây là tác động xã hội lớn và góp phân ổn định sinh kế người dân lâu dài ngoài giá trị kinh tế đem lại.

Ngoài ra, tác động của PFES đối với cộng đồng cũng đáng được ghi nhận khi nhờ có nguồn thu này, điều kiện cơ sở vật chất của các nhà văn hóa cộng đông được nâng cao tạo điều kiện cho các hoạt động giao lưu văn hóa được diễn ra thường xuyên hơn. Cũng nhờ có nguôn thu từ PFES, các tổ chức xã hội như Hội Phụ nữ và Hội Nông dân có thêm nguồn thu hỗ trợ cho các thành viên của mình làm kinh tế, đông thời nâng cao sự tham gia của họ vào công tác bảo vệ và phát triển rừng. Đây là cũng là một nguôn lực xã hội quan trọng của địa phương.

Kết quả nghiên cứu cho thấy, mặc dù PFES đã được triển khai trong một thời gian dài ở $\mathrm{A}$ Lưới, nhận thức của người dân về PFES còn rất hạn chế. Việc phần lớn các hộ dân tham gia khảo sát không rõ việc họ kí hợp đồng bảo vệ rừng với chương trình nào, tiền PFES được quản lý ra sao. Điều này đòi hỏi các chương trình truyền thông và nâng cao nhận thức, chia sẻ thông tin về PFES cần được tiến hành hiệu quả hơn, đặc biệt với cộng đồng người dân tộc thiểu số vốn có nhiều rào cản ngôn ngữ với tiếng Kinh đang được sử dụng. Vai trò của trưởng thôn trưởng bản rất quan trọng trong việc chuyển giao các thông tin đây đủ tới cộng đông địa phương nên cân có nhiều hỗ trợ nâng cao năng lực cho trưởng bản, đặc biệt trong quá trình quản lí và sử dụng tiền PFES công khai và minh bạch.

PFES đã tạo ra nguôn tài chính mới và huy động nguồn lực xã hội vào công tác bảo vệ và phát triển rừng. Tuy nhiên, để thực hiện PFES hiệu quả hơn, cân hoàn thiện quá trình giao đất giao rừng cho cộng đông và người dân đông thời lông ghép có hiệu quả các chính sách, chương trình, dự án hỗ trợ vể lâm nghiệp như làm giàu rừng, trồng cây dược liệu, để phát huy tối đa nguôn lực thúc đẩy phát triển kinh tế, nâng cao đời sống mang tính bền vững đồng thời cải thiện chất lượng rừng. Để đánh giá về hiệu quả và tác động của PFES, cân có thêm nhiều nghiên cứu tiếp theo bởi các tác động của PFES cần được kiểm chứng trong thời gian ngắn hạn, trung hạn và dài hạn. 


\section{Tài liệu tham khảo}

BT. (2019, 1 31). Tăng cuiờng công tác quản lý rừng tại huyện A Lưới. Retrieved from ANTV: https://www.antv.gov.vn/tin-tuc/xa-hoi/tangcuong-cong-tac-quan-ly-rung-tai-huyen-aluoi-263823.html

Cục Thống Kê Tỉnh Thừa Thiên Huế. (2012). Niên Giám Thống Kê Tinh Thưa Thiên Huế năm 2011:. Huế: Nhà xuất bản thống kê.

Cục Thống Kê Tỉnh Thừa Thiên Huế. (2020). Niên Giám Thống Kê Tỉnh Thưa Thiên Huế năm 2019. Hue: Nhà xuất bản thống kê.

DT. (2019, 12 6). Kết quả thực hiện nhiệm vu phát triên kinh tếxã hội năm 2019. Retrieved from Trang Thông tin điện tử huyện $\mathrm{A}$ Lưới: https://aluoi.thuathienhue.gov. $\mathrm{vn} /$ ?gd $=21 \& \mathrm{cn}=254 \& \mathrm{tc}=16341$

Grieg-Gran, M., Porras, I., \& Wunder, S. (2005). How can market mechanisms for forest environmental services help the poor? Preliminary lessons from Latin America. World Development, 33(9), 1511-1527. doi:https://doi.org/10.1016/j. worlddev.2005.05.002

Huệ, L. T., Tuyến, N. P., Hương, V. D., \& McElwee, P. (2013). Đánh giá tác động của cơ chế chi trả cho hấp thụ cacbon đến ra quyết định và tính dễ bị tổn thương của hộ gia đình với $\mathrm{B} Đ K H$ ở Việt Nam. Nâng cao sức chống chịu truiớc biến đổi khí hậu. Kỷ yếu Hội thảo khoa học quốc gia. Hạ Long, 10/11/2012 (pp. 285-308). Hà Nội: Trung tâm NC TN\&MT, ĐHQGHN. NXB Khoa học và Kỹ thuật.

Huong, T. T., Zeller, M., \& Suhardiman, D. (2016). Payments for ecosystem services in Hoa Binh province, Vietnam: An institutional analysis. Ecosystem Services, 22A, 83-93.

Landell-MillsIna, N., \& Porras, T. (2002). Silver bullet or fools' gold: a global review of markets for forest environmental services and their impact on the poor. London, UK: International Institute for Environment and Development.
Ngoc, D. T., \& de Groot, W. T. (2018).

Distributional risk in PES: Exploring the concept in the Payment for Environmental Forest Services program, Vietnam. Forest Policy and Economics, 92, 22-32.

Ngoc, D. T., \& Groot, W. d. (2020). The impact of payment for forest environmental services (PFES) on community-level forest management in Vietnam. Forest Policy and Economics, 102135. doi:102135

Pagiola, S. (2003). Can programs of Payments for Environmental Services help preserve wildlife. Convention on International Trade in Endangered Species of Wild Fauna and Flora. Workshop on Economic Incentives and Trade Policies. Geneva: World Bank.

Phú, N. T. (2009). Vai trò của Chính phủ trong việc xây dựng và triên khai chính sách Chi trả dịch vu môi trường rüng - PFES” ở Việt Nam. Hà Nội: Văn phòng Điều phối đối tác hỗ trợ ngành lâm nghiệp,.

Quỹ Bảo vệ và Phát Triển Rừng tỉnh Thừa Thiên Huế. (2020). Báo cáo chi trả dịch vụ môi trương rüng tư năm 2015-2019. Hue: Quỹ Bảo vệ và Phát Triển Rừng tỉnh Thừa Thiên Huế.

Thuy, P. T., Nga, D. T., Chi, D. T., Tien, N. D., Thang, L. M., Trung, P. V., . . Dung, L. N. (2019). Payment for Forest Environmental Services (PFES) policy learning tool: A case study from Vietnam. Bogor, Indonesia: Center for International Forestry Research (CIFOR).

Toán, L. T. (2014). Chi trả dịch vụ môi trường rüng và sinh kế cộng đông: trường hợp nghiên cứu tại xã Chiêng Cọ, thành phố Sơn La, tỉnh Sơn La. Hà Nội: Đại học quốc gia Hà Nội.

Wunder, S. (2008). Payments for environmental services and the poor: Concepts and preliminary evidence. Environment and Development Economics, 13(3), 279-297. doi:10.1017/S1355770X08004282 

Các báo cáo chuyên đề của CIFOR chuyển giao các kết quả nghiên cứu quan trọng đối với ngành lâm nghiệp. Nội dung của báo cáo đều được đánh giá bởi các chuyên gia trong và ngoài tổ chức.

Báo cáo này đưa ra một bức tranh tổng thể về đời sống của những người dân sinh sống tại 12 thôn của huyện $\mathrm{A}$ Lưới, tỉnh Thừa Thiên Huế và vai trò của Chính sách Chi trả dịch vụ môi trường rừng (PFES) đối với sinh kế và đời sống xã hội nơi đây. Báo cáo chỉ ra rằng, PFES đã tạo ra nguồn tài chính mới và huy động nguồn lực xã hội vào công tác bảo vệ và phát triển rừng. Tuy nhiên, để thực hiện PFES hiệu quả hơn, cần hoàn thiện quá trình giao đất giao rừng cho cộng đồng và người dân đồng thời lồng ghép có hiệu quả các chính sách, chương trình, dự án hỗ trợ về lâm nghiệp và phát triển sinh kế cho người dân để phát huy tối đa nguồn lực thúc đẩy phát triển kinh tế, nâng cao đời sống mang tính bền vững đồng thời cải thiện chất lượng rừng. Cần có nhiều nghiên cứu trong tương lai đánh giá hiệu quả và tác động của PFES trên toàn địa bàn tỉnh Thừa Thiên Huế với nhiều nhóm chủ rừng khác nhau.

\begin{tabular}{|c|c|c|}
\hline พิ1\% & $\begin{array}{l}\text { RESEARCH } \\
\text { PROGRAM ON } \\
\text { Forests, Trees and } \\
\text { Agroforestry }\end{array}$ & $\begin{array}{l}\text { Chương trình nghiên cứu CGIAR về Rừng, Cây và Nông lâm kết hợp (FTA) là chương trình nghiên cứu phát } \\
\text { triển lớn nhất trên toàn cầu nhằm nâng cao vai trò của rừng, cây, và nông lâm kết hợp trong phát triển } \\
\text { bên vững, đảm bảo an ninh lương thực và thích ứng và giảm thiểu biến đổi khí hậu. CIFOR điêuu phối FTA } \\
\text { và hợp tác với ICRAF, Liên minh đa dạng sinh học quốc tế, CIAT, CATIE, CIRAD, INBAR và TBI. }\end{array}$ \\
\hline CUAN & & Các nghiên cứu của FTA cũng nhận được sự tài trợ của Quỹ Ủy thác CGIAR: cigar.org/funders/ \\
\hline
\end{tabular}

cifor.org

forestsnews.cifor.org

Tổ chức Nghiên cứu Lâm nghiệp Quốc tế (CIFOR)

CIFOR thúc đẩy sự phồn vinh của nhân loại, cải thiện bảo vệ môi trường và thúc đẩy sự bình đẳng thông qua tiến hành các nghiên cứu sáng tạo, nâng cao năng lực của các bên đối tác, tích cực tham gia đối thoại với các bên liên quan để hỗ trợ định hình chính sách và thực tiễn tác động tới rừng và con người. CIFOR là tổ chức nghiên cứu thuộc liên minh CGIAR và chủ trì các chương trình nghiên cứu của CGIAR về Rừng, Cây gỗ và Nông lâm kết hợp (FTA). Trụ sở chính của CIFOR đặt tại Bogor, Indonesia và các văn phòng của CIFOR có mặt tại Nairobi, Kenya; Yaounde, Cameroon; Lima, Peru và Bonn, Germany. 